\title{
ESSAYS
}

\section{INSTITUTIONALIZATION OF MEANING, RECOLLECTIVE IMAGINATION AND THE POTENTIAL FOR TRANSFORMATIVE LEGAL INTERPRETATION}

\author{
Drucilla L. Cornell $\dagger$
}

\section{INTRODUCTION}

In his New Science, ${ }^{1}$ Giambattista Vico provided us with four axioms, which if followed, could help prevent us from falsifying our knowledge of history and our understanding of ourselves. ${ }^{2}$ Although all four axioms are relevant, the last two- "the conceit of nations" and "the conceit of scholars"-are particularly important as reminders to American legal scholars who all too often fall prey to the very dangers Vico seeks to warn us against. ${ }^{3}$ The third axiom, "the conceit of nations," points to a nation's mistaken belief "that it before all other nations invented the comforts of human life and that its remembered history goes back to the very beginning of the world." The fourth axiom, "the conceit of scholars," points to the mistaken belief of scholars "that what they know is as old as the world," and indeed, that the significance of the history of knowledge and of philosophy-if such history has any significance at all-lies in its prefiguration in a primitive form of more recent scholarly insights and truths. ${ }^{6}$ The scholarly conceit, in other words, is the belief that the work of scholars before

† Assistant Professor at the University of Pennsylvania Law School. J.D. 1981, University of California at Los Angeles Law School. This Essay is dedicated to three friends, Regina Austin, Gary Francione, and Alan Watson, whose intellectual support played such an important role in its creation. I would also particularly like to thank Bruce Ackerman, Richard Bernstein, David Carlson, Frank Goodman, Frank Michelman, Gerry Neuman, and Cass Sunstein for their helpful comments on this Essay.

3 G. Vico, The New Science of Giambattista Vico (1971).

2 See id. पा 120-28.

${ }^{3}$ Id. IT $127-28$.

Id. ๆ 125.

- Id. II 127.

${ }^{6}$ See id. If 128. 
us-particularly those from other countries-was only, and in a relatively poor way, to anticipate what we do so much better now. Accordingly, if the history of knowledge culminates in our present insight, why even bother to look backward, except possibly out of mere curiosity or scholarly interest; let us instead move forward from our new beginning.

We can, of course, see a positive aspect of the scholarly conceit, at least as it is practiced by American legal scholars. The western philosophical tradition does not press down against the creative impulse. There is a boldness and an enthusiasm that seems to accompany the contempt for the history of philosophy--particularly the "opaque," continental tradition-and the belief that we are developing truly new perspectives.

A much more important aspect of American legal scholars' scholarly conceit, however, is the negative aspect-the waste involved in reinventing the wheel. Yet, this may not be the only problem. A more serious problem is that our purportedly new inventions may not be nearly as good as the ones that have already been created. Errors, long since discovered and corrected, go unrecognized and are repeated again and again. It is not, then, just that we are inaccurate when we declare what is old to be new. Our more serious mistake is to think that we must always go around in our own circles before we can find solutions to the legal problems we face.

The reason to work carefully through the "dead Europeans," then, is not for the sake of historical accuracy. The reason we should turn to them is that they often offer us the most sophisticated starting point from which to begin the task of solving our contemporary legal dilemmas. I am not, however, advocating that we can simply go back in the history of philosophy and find the solutions to our most burning contemporary problems. I am suggesting that we should begin with the most sophisticated presentation available of the problems we are addressing, wherever that beginning may be.

The drawback inherent in the "scholars' conceit" has been evident in the debates on the possibility and role of objectivity in legal interpretation. Much would have been gained and still remains to be gained if we incorporate the insights of the "dead Europeans" into the debates in American legal circles over the dilemma of legal interpretation and the problem of the nature of community. It is not a coincidence, then, that I begin this essay with a warning that should be well taken, a warning from a "dead European," Vico.

Of course, it is only to the good that it is now widely accepted that law, particularly adjudication, is fundamentally an interpretive process. 
I want to stress the word "fundamentally." It has long been recognized that interpretation was inevitable in the hard cases that were not governed by clear precedent. The corresponding hope was that the "activism" of the judge in the interpretive process would be limited only to hard cases-those cases would be the ones in which it was absolutely necessary. The basis for that hope was an implicit belief that there is usually a plain and obvious meaning to the words that make up the precedents, the statutes, and the regulations involved in a particular case and therefore in most cases the judge could simply lift the meaning out of precedent and apply the law without interpreting it.

The "plain meaning" view of language is linked intrinsically to the traditional notion of legal positivism developed by John L. Austin ${ }^{7}$ and H.L.A. Hart. ${ }^{8}$ In Hart's correction of what he took to be Austin's simplistic reduction of law to the brute facts of command and obedience, he argued that law rests on the acceptance of the "master rule of recognition" which effectively empowers particular institutions to make law. ${ }^{9}$ However, even in Hart's corrected version of legal positivism, the certitude of the law is dependent on the self-evidence of its meaning. It is precisely this self-evidence of meaning that the interpretive turn in law has called into question. For example, people can agree that the National Labor Relations Act ("NLRA") 10 is law, because it was enacted by the body recognized as the appropriate power in our social order, and still violently disagree about what the law of the NLRA actually is. On an even more basic level, the "master rule of recognition" is itself open to interpretation. Legal positivism, then, does not solve the problem of legal interpretation, unless one accepts the plain meaning view of language.

The plain meaning view of language has long since been effectively deconstructed by Wittgenstein's critique of the absolute determinacy of either Sinn or Bedeutung. In his Philosophical Investiga-

7 See J. Austin, The Province of Jurisprudence Determined and the USES OF THE STUDY OF JURISPRUDENCE (1954); J. AUSTIN, LeCTURES ON JURISPRUDENCE $\S \S 189-344$ (1875).

8 See H.L.A. Hart, The Concept of Law (1961).

- See id. at 97-107.

10 Section 1 of the National Labor Relations Act as amended by the Labor Management Relations Act provides:

It is declared to be the policy of the United States to eliminate the causes of certain substantial obstructions to the free flow of commerce . . . by encouraging the practice and procedure of collective bargaining and by protecting the exercise by workers of full freedom of association . . . for the purpose of negotiating the terms and conditions of their employment or other mutual aid or protection.

Labor Management Relations (Taft-Hartley) Act, 29 U.S.C. § 151 (1982). 
tions, ${ }^{11}$ Wittgenstein demonstrated that his own attempt in the Tractatus $^{12}$ to protect against the errancy of language through the identification of the form of the word with the form of the entity necessarily fails. ${ }^{13}$ Meaning is not just there like a dead object which is present for us to grasp and then to apply. Meaning only comes to life within a form of life.

Does Wittgenstein's deconstruction which recognizes the individual's inevitable participation in the perpetuation of shared meaning as well as in the reactivation and expansion of the range of interpretation mean that her involvement is merely subjective? Is the interpreter free to do as she wishes? If we cannot cement meaning are we left with nihilism? Owen Fiss has given eloquent voice to the mood of anxiety that has arisen with the growing recognition that law is fundamentally an interpretive process:

The new nihilism might acknowledge the characterization of adjudication as interpretation, but then would insist that the characterization is a sham. The nihilist would argue that for any text-particularly such a comprehensive text as the Constitution-there are any number of possible meanings, that interpretation consists of choosing one of those mean-

11 L. Wittgenstein, Philosophical Investigations (G. Auscombe trans. 1953) [hereinafter Philosophical Investigations]. See, for example:

We are under the illusion that what is peculiar, profound, essential in our investigation, resides in its trying to grasp the incomparable essence of language. That is, the order existing between the concepts of proposition, word, proof, truth, experience and so on. This order is a super-order between-so to speak-super concepts. Whereas, of course, if the words "language", "experience", "world", have a use, it must be as humble a one as that of the words "table", "lamp", and "door".

Id. \ 97.

12 L. Wittgenstein, Tractatus Logico-Philosophicus (D. Rears \& B. McGuiness trans. 1958) [hereinafter Tractatus]. In the Tractatus, Wittgenstein attempted to identify general forms of language from propositions:

3.31 Every part of a proposition which characterizes its sense I call an expression (a symbol).

(The proposition itself is an expression.)

Expressions are everything-essential for the sense of the proposition-that propositions can have in common with one another.

An expression characterizes a form and a content.

3.311 An expression presupposes the forms of all propositions in which it can occur. It is the common characteristic mark of a class of propositions. 3.312 It is therefore represented by the general form of the propositions which it characterizes. variable.

And in this form the expression is constant and everything else is

Id. ๆा $3.31-.312$.

${ }^{13}$ See id. II 4.002. 
ings, and that in this selection process the judge will inevita-

bly express his own values. All law is masked power. ${ }^{14}$

If we are to separate subjectivism from the recognition of meaning as an activity that involves the individual, we must look more closely at what interpretation entails. We must, in other words, develop a theory of legal interpretation that is "anti-foundationist" without falling back into legal positivism.

The favored solution to the danger of nihilism current within American legal circles is the appeal to the institutionalization of communitarian standards of shared meaning. Fiss himself has sought to overcome the danger of nihilism through the appeal to established community practices. ${ }^{15}$ But this solution without an explicit appeal to the normative basis of community only replicates legal positivism. If widely shared, the appeal to the community itself takes different forms, each with its own implicit understanding of the nature of law and of the role of community and each ultimately inadequate. Stanley Fish, for example, has argued that for all the fanfare, the problem of nihilism or radical subjectivism in interpretation is nonexistent because such a phenomenon is impossible. ${ }^{16}$ For Fish, there is no logical space for self that has the capacity to reflect on an institutionalized form of life-and legal practice is just that for Fish, an institutionalized form of life. According to Fish, the subject is completely identified with the professional or communitarian roles by which she has been constituted. ${ }^{17}$ Fish seeks to block the very idea that there is a subject who can impose his or her own values. For Fish, meaning is the reigning convergence of opinion within the community of interpreters-nothing more, nothing less. However, meaning is not something that the community develops and critiques; meaning is instead identified as the institutionalized context that operates behind the backs of individuals. In his later writings, Fish has even become suspicious of the lingering subjectivist overtones of the phrase "community of inquirers or interpreters." idea of a community of interpreters, while it may displace the illusion of individualism, still leaves open the space for collective choice and collective responsibility. Yet, according to Fish, what we cannot do in-

${ }^{14}$ Fiss, Objectivity and Interpretation, 34 STAN. L. REv. 739, 740-41 (1982).

15 See id. at 745.

${ }^{16}$ See, for example, the exchange between Dworkin and Fish: Dworkin, Law as Interpretation, 60 TEX. L. REv. 527 (1982); Fish, Working on the Chain Gang: Interpretation in Law and Literature, 60 TEx. L. REv. 551 (1982); Dworkin, My Reply to Stanley Fish (and Walter Benn Michaels): Please Don't Talk About Objectivity Any More, in The Politics of InTERPRETation 287 (W. Mitchell ed. 1983).

${ }_{17}$ See S. Fish, Is There a TeXt in This Class? 303-04 (1980).

${ }^{18}$ See Fish, supra note 16, at 555 . 
dividually-effectively criticize institutionalized meaning-we also cannot do collectively. ${ }^{19}$ For Fish, anti-foundationalism is positivism.

Like Fish, Ronald Dworkin, in his recent book Law's Empire, ${ }^{20}$ tries to counter the idea that we will be left with nihilism if we accept that interpretation is necessary for adjudication. But Dworkin also condemns Fish's conventionalism--and indeed, conventionalism more generally-for its reinscription of the legal positivism he rejects. According to Dworkin, conventionalism blurs the fundamental distinction between what an existing community takes to be authority and its claim to normative authority. Although Dworkin is often thought to offer us a coherence theory of meaning to counter nihilism, his real concern is less with the institutionalization and maintenance of linguistic meaning than with the role of consistency in principle, as a normative ideal, an idea crucial for the legitimation of the legal system. ${ }^{21}$ Dworkin understands that normative authority cannot be established simply by an appeal to community, but only by an appeal to a properly constituted community. ${ }^{22}$

19 See Fish, Anti-Professionalism, 7 Cardozo L. Rev. 645, 673-74 (1986) ("anti-professionalism"-the criticism of institutionalized meaning-is itself a form of professionalism and is therefore invalid).

${ }^{20}$ R. DWORKIN, LAw's EMPIRE (1986).

21 See id. at 120-24.

${ }^{22}$ See id. at 188-90. Dworkin's rightful concern with normative authority is also evident in his rejection of legal pragmatism. It should be noted here that what Dworkin calls legal pragmatism has almost nothing to do with the American philosophical tradition that goes by that name. He instead uses legal pragmatism as a label to designate the legal realists and their more recent counterparts in the Conference of Critical Legal Studies. Even when we have limited Dworkin's understanding of pragmatism to the groups in American legal scholarship he has in mind, the picture we are given of the pragmatist still seems like a caricature. For Dworkin, the legal pragmatist is an instrumentalist whose vision is solely directed to the future and who uses law only to implement a blueprint of the best possible society he can imagine. See R. Dworkin, supra note 20 , at 160 . The pragmatist values law for its strategic usefulness. As a result, the pragmatist rejects in principle "[t]he assumption that past decisions provide rights to future ones." Id. at 101. The real concern here is that legal pragmatism undermines the claim to normative authority of the legal system, because "the pragmatist thinks judges should always do the best they can for the future, in the circumstances, unchecked by any need to respect or secure consistency in principle with what other officials have done or will do." Id. at 161.

For Dworkin, the only view of interpretation that can support the legal system's claim to normative authority is the one he adopts, integrity. See id. at 226-27. Integrity provides us with the standard by which we can distinguish between what a community takes to be authority and its claim to legitimate authority. Dworkin maintains that, within the interpretive frame provided by law as integrity, "propositions of law are true if they figure or follow from principles of justice, fairness, and procedural due process that provide the best constructive interpretation of the community's legal practice." Id. at 225 . Coherence is only the first step in the process of interpretation. There can be competing interpretations of precedent, all of which are equally coherent. Law as integrity demands that the judge participate in the perpetuation of the ethical and legal tradition so as to provide us not only with a coherent story, but with the one that gives 
Yet in spite of his recognition of the need to appeal to a properly constituted community as the only basis for normative authority in legal interpretation, Dworkin's own break with legal positivism remains incomplete. If then Dworkin has insight into the fundamental flaw of Fish's conventionalism, his own conception of community is inadequate. Dworkin's own conception of the community personified also fails because it does not give us a view of community at all, but instead, leaves us with a mythical individual whose proclamations stand in for communal ethics. Dworkin, in other words, understands that legal interpretation must appeal to a properly constituted community but he, unfortunately, does not offer us an adequate explanation of the "being" of such a community. As a result, he cannot avoid the subjectification of the community. Correspondingly, he cannot offer us a convincing account of how embodied communal ethical ideals can provide us with public standards for assessing whether or not our community is properly constituted that are not reducible to the individual moral opinions of the judges.

There is yet a further difficulty in Dworkin's vision of law as integrity and his advocacy of integrity as the basis for a legal community of principle. Integrity, according to Dworkin's own understanding of his project, which is to protect the rule of law against the danger of the radical subjectivism he associates with legal pragmatism, cannot justify both fidelity to past precedent and infidelity to it in the name of reconstructed principle. Integrity, in other words, can only justify the rule of law, never the necessary break with precedent in the name of principle. In order to justify such a break, we must explicitly enunciate the principles to which we are to be faithful that can override fidelity to the institutionalized meaning of past precedent. I will also argue that Dworkin cannot maintain the divide he insists upon between the enunciation of the "should be", inherent in legal principle, from theoretical disputes about what the law is. But more importantly, I will suggest that his inability to maintain this divide need not be a concern to us, once we understand that the "should be" to which we appeal in the enunciation and justification of legal principle inheres in the collective ethics embodied in our legal system, and not simply in the individual, subjective vision of the judge.

the best possible justification in principle for a particular legal practice. The particular dispute is to be resolved within an appeal to the whole, the whole here being Dworkin's community of principle. The achievement of rational coherence and the best possible justification of legal principle is the goal for the judge in the resolution of any particular case. For Dworkin, law as integrity is the only view of law as interpretation that gives full weight to the value we give to the rule of law, with its emphasis on continuity as the basis or ground of right. 
The significance of the failure to grasp law as collective ethics, which embody, if imperfectly, the "should be" of expressed ethical ideals-ideals which can potentially pull us toward a different future and which allow us to reinterpret the weight of past precedent through an appeal to the "might have been"-is evident in Dworkin's "rose colored glasses" method of legal interpretation. If we cannot appeal to the "should be" of embodied ideals, then when we reinterpret precedent we must try to show that our reinterpretation is based on what the law actually was, even if it is also paradoxically to be glimpsed in its best light. My point will be that Dworkin does not resolve satisfactorily the paradox he inadvertently creates. Dworkin, in other words, wants to insist that we are only appealing to the "is" or "was" of the community when we reinterpret past precedent and not to the "should be" or "should have been." But there is a serious danger in his approach. When Dworkin puts on his "rose colored glasses" he becomes the great pretender. The weight of the ugliness of history cannot simply be interpreted away by pretending that our community was "always and already" a community of principle. By so pretending, he both undercuts the full potential of transformative interpretation and thwarts the possibility of critique of the "past" of our community. Dworkin's "rose colored glasses" are not a coincidence, but a necessary expression of his incomplete break with the positivist insistence, itself a result of his battle against legal pragmatism, that all we can do is appeal to the "was" or the "is" of law and not to the "should be" because the "should be" can never be more than the individual's own opinion.

After examination of Dworkin's own solution to the dilemma of legal interpretation, we will begin again in Part IV, but this time with Hegel. The reason to begin again with Hegel is that Hegel, like Dworkin, recognizes the centrality of the problem of normative authority in the legitimization of a modern legal state. On the other hand, Hegel, unlike Dworkin, does offer us a convincing portrayal of community and the role of justice in the establishment of legal obligation. The Hegelian recognition of the reality of Sittlichkeit ${ }^{23}$ _or our concrete, communal ethics-provides us with an actualized interpretative framework as the basis for an appeal to institutionalized meaning against subjectivism and, at the same time, gives us an understanding of the inherently ethical nature of law and of legal debates. Legal interpretation does not only or even primarily have to do with the exposition of the meaning of

${ }^{23}$ See G.W.F. Hegel, Philosophy of Right II 33 (T. Knox trans. 1952) [hereinafter PHILOSOPHY OF RIGHT]; see also Knox, Translator's Notes, in id. If 33 n.75 (describing the difference between Moralität and Sittlichkeit and describing the latter as meaning "concrete morality"). 
the sentences in cases, but with the elaboration of the ethical significance of the legal principles of right involved. This is exactly the point Dworkin tries to make, but because he separates law from morality and does not introduce the difference between communal ethics and individual morality, he has difficulty in fully explaining the inherently ethical nature of legal debate. ${ }^{24}$

Community, in Hegel, is not reduced to a mythical individual as in Dworkin. Community is instead understood as the reality of our own internal interrelatedness. The individual is itself a social achievement embodied in the legal recognition of right. The Hegelian recognition of both the reality of Sittlichkeit and the reality of legally protected individuality in relations of reciprocity allows Hegel to give a rich explanation for communal and legal obligation. According to the interpretation of Hegel offered in this Essay, we are only obligated to belong to our community because it protects the relations of reciprocity which are the very basis for the development of the autonomous legal person. Yet, for all of Hegel's insight into the communal basis of normative authority in a modern democratic, legal state, the significance of Hegel's attempt to reveal a total philosophical system must be confronted if we are to incorporate Hegel's institutional analysis of the democratic state into a modern and, indeed, post-modern conception of legal interpretation. ${ }^{25}$

The main difficulty inherent in Hegelianism is the time frame of his recollective science. There is no room in Hegel for a prospective construction of legal principle. Hegel's philosophy of right, in this

24 For Hegel, law is the public, formal, codified expression of Sittlichkeit. Sittlich obligation on the part of the judges (and the citizens, too, for that matter) enjoins individuals to appropriate an already existing social and ethical practice. Our ethical tradition is not external to us but is instead the matrix in and through which we become who we are.

${ }^{28}$ On one reading, Hegel's Absolute or Geist is transformed into a deified subjectivity. See PhILosophy of RIGHT, supra note 23, II 279; Translator's Addition, in Philosophy of Right, supra note 23, II 52. In Hegel's social philosophy, the reification of Geist has been read to lead to the elevation of the state to a higher level of subjectivity in which the communal interaction of the citizens is effectively undermined. See Williams, Hegel's Concept of Geist, in Hegel's Philosophy of SPIRIT 1 (P. Stillman ed. 1987). I do not completely deny the teaching in Hegel that has been emphasized in this interpretation, but I do want to suggest that it is one-sided.

For all his insight into the intersubjective constitution of the self, the later Hegel fails to grasp the full significance of the collective interchange of an actual living community of human beings. See PhILosophy of Right, supra note 23, II 318 ("Public opinion therefore deserves to be as much respected as despised . . . ."). Hegel's democratic state is not a participatory democracy. As we will see, the pragmatic critique of Hegelianism as a system has had political consequences. The need for actual participatory structures in a democratic state, something that Hegel completely ignored, is now emphasized. 
sense, is inherently conservative in that it ties us to the rock of the past. If we are to develop an adequate account of the role of the imagination in legal interpretation we will have to move beyond both Dworkin and Hegel. I will argue that legal interpretation should be understood as recollective imagination. I will then distinguish recollective imagination from Dworkin's pretending.

We can begin to flesh out the significance of understanding legal interpretation as recollective imagination by examining the rebellion against Hegel's system in the name of indeterminacy. In American legal circles, the very word "indeterminacy" signals nihilism and the end of principle. ${ }^{26}$ We do not have to tremble in fear every time we hear the word, as we will see as we look at what "indeterminacy" means in the work of one of the most powerful rebels against Hegel's system, Charles Sanders Peirce. ${ }^{27}$ What we are forced to conclude once we have learned the "truth" of indeterminacy is that social reality is never fully present to itself but always contains potential, or what Peirce would call the "would be."28 As a result, there cannot be a solely retrospective philosophy of right which simply reads off the legal ideal as it has been made fully determinate in history. Legal interpretation is never just exposition of an "existing" principle; it is also a positing of the very principle it reads into the case law through the enunciation of the "should be" inherent in the justification of principle. ${ }^{29}$ But indeterminacy does not eradicate the necessary distinction between de jure and de facto authority.

Indeed, Peirce always emphasized the inherently normative basis of an appeal to a community of inquirers as the basis for shared meaning. ${ }^{30}$ The appeal to community does not, then, as Fish would have it,

${ }^{26}$ See infra text following note 199.

${ }^{27}$ See infra notes 203-05 and accompanying text. By indeterminacy, I mean to indicate the "truth" that without the fusion of meaning and being in Absolute Knowledge there can be no end of the interpretive process in a definitive grasp of the truth of the actual.

The cohesion of meaning and being reconciles the subject and the object through the determination of the object in and through Geist, the self-differentiating absolute. G.W.F. Hegel, The Science of Logic 831 (A. Miller trans. 1976) [hereinafter LoGic]. The reality of meaning and being within the circle of the Absolute yields full knowledge of the truth of the essence of the actual.

${ }^{28}$ See 5 Collected Papers of C.S. Peirce $\int 467$ (C. Harstshorne \& P. Weiss ed. 1960) [hereinafter C.S. PErRCE].

${ }^{29}$ For Peirce, at least in his early writings, the self is only a locus of habits. See 1 C.S. PEIRCE, supra note 28 , II 50 ("[I]t is the law of habit that [habit] tends to spread and extend itself over more and more of the life."). Peirce himself, however, came to be dissatisfied with his own emphasis on habituation. See 5 C.S. PEIRCE, supra note 28, II 487.

${ }^{30}$ See Smith, Community and Reality, in Perspectives on Peirce 108-10 (R. Bernstein ed. 1965); see also 5 C.S. PeIRCE, supra note 28, f 407 ("The opinion . . . 
collapse the ideal into the real. Because this distinction is crucial in legal interpretation, Peirce's work on community is extremely important for legal thinkers. ${ }^{31}$ But Peirce himself continued to project an ultimate convergence of opinion in the community as a regulative ideal. I will reject even Peirce's hypothetical projection of closure.

The invitation to think again and to see the world differently always remains. An adequate understanding of legal interpretation cannot be found simply in Hegel or in Peirce, but by beginning with their insights we can avoid the repetition of unnecessary mistakes and develop an understanding of legal interpretation as recollective imagination through the retrieval of the embodied ideals of law, a retrieval that releases the power of the "might have been" through an appeal to the "should be." The structure of the Essay itself seeks to embody the "truth" of the communal view of individuality I develop. Why speak in and through the choreography of dialogue with others rather than simply present one's own truth as if it originated with the self? The answer is very simple. To present my argument as if it could be other than in a dialogue would be to reject the central insight that our individual reality is socially constructed in and through dialogue with others. The me is always constituted in and through the we. To know oneself as that we demands that we write differently. The choreography of this Essay is an attempt at fidelity to the truth I present.

\section{DWORKIN'S UNDERSTANDING OF LAW AS INTEGRITY}

\section{A. The Radical Divide}

Dworkin's arguments are frequently difficult to pin down. But the

agreed to by all who investigate, is what we mean by the truth, and the object presented in this opinion is real.").

31 We can use Peirce to criticize Fish's positivism. See infra notes 206-23 and accompanying text. Our own legal community would be well served if we were to pursue the Peircean ideals of melioristic fallibilism and dialogic reciprocity.

For all Peirce's insight into the "would be" inherent in an indeterminate present, and even given his profound awareness of the danger of the uncritical acceptance of established communitarian standards internalized in the very habitual structure of human thinking, Peirce remained optimistic about the possibility and desirability of the convergence of opinion within the relevant community of inquirers. Peirce, in other words, projected a hypothetical closure in which the truth of the real would be disclosed. It is extremely important to note that Peirce usually refers to the possibility of convergence as a regulative ideal always projected into the future. Closure is projected into the future because the community of inquirers is to remain a normative, regulative ideal. Even so, critics of Peirce have stressed the danger of closing down the process of interpretation in even a projected or hypothetical closure, and they are right to do so. See Smith, supra note 30, at 117 ("Royce saw that if to have a real object means a process of inquiry then that process must have an actual issue or fulfillment, and if it does not, we are left with an abstraction."). 
reconstruction of Law's Empire I will offer is necessary for his own project once we understand that his fundamental objective is to rehabilitate the integrity of the rule of law so as to distinguish it sharply from what he calls legal pragmatism. Although there are obviously different interpretations that can be given to the role Dworkin gives to conceptual determinacy in the interpretation of past precedent, he must, in spite of his own seeming vacillation, insist on such determinacy if he is to establish a position that is indeed distinguishable from legal pragmatism. Accordingly, I will argue as if this were his point of view. If one accepts that he does insist on the conceptual determinacy of the past by precedent, then his group novel is absolutely essential to his project in Law's Empire. I also want to suggest that once we understand Dworkin as an embryonic Hegelian we can unravel some of the strands in his own argument and sew them together again into a framework that allows us to tell a more coherent narration of legal interpretation and community than the one Dworkin himself offers us. In this sense, I can be understood in the best of the Hegelian tradition to be perfecting Dworkin, not simply rejecting him.

In Law's Empire, Dworkin has accepted the position that law is essentially an interpretive enterprise. In the opening pages, he sets out to defeat the positivist challenge to his own view of law as interpretation. He calls the challenge to his own position the plain fact view of law. ${ }^{32}$ Such a view holds that theoretical disagreement about what the law is is impossible and, therefore, interpretation is unnecessary. ${ }^{33}$ What we are really disagreeing about in the guise of interpretive debates, so the argument goes, is not what the law is, but only what it should be. ${ }^{34} \mathrm{An}$ appeal to the reality of disagreement in interpretation is either an excuse for the introduction of morality into the law or merely our "empirical disagreement about what legal institutions have actually decided in the past." 35 The plain fact view of law argues that there can be no theoretical disagreement about what the law is, because the very meaning of the word "law" supposedly holds within it certain criteria which can be known and which cannot be challenged without falling into self-contradictory nonsense. Dworkin summarizes the plain fact view of law in the following way:

We follow shared rules, they say, in using any word: these rules set out criteria that supply the word's meaning. Our

\footnotetext{
32 See R. Dworkin, supra note 20, at 6-11.

${ }^{33}$ See id. at 7 .

s4 See id.

ss $I d$. at 31 .
} 
rules for using "law" tie law to plain historical fact. It does not follow that all lawyers are aware of these rules in the sense of being able to state them in some crisp and comprehensive form. For we all follow rules given by our common language of which we are not fully aware. We all use the word "cause," for example, in what seems to be roughly the same way-we agree about which physical events have caused others once we all know the pertinent facts-yet most of us have no idea of the criteria we use in making these judgments, or even of the sense in which we are using criteria at all. It falls to philosophy to explicate these for us. . . . A philosopher's account of the concept of causation must not only fit, moreover, but must also be philosophically respectable and attractive in other respects. It must not explain our use of causation in a question-begging way, by using that very concept in its description of how we use it, and it must employ a sensible ontology. We would not accept an account of the concept of causation that appealed to causal gods resident in objects. So, according to the view I am now describing, with the concept of law. We all use the same factual criteria in framing, accepting, and rejecting statements about what the law is, but we are ignorant of what these criteria are. Philosophers of law must elucidate them for us by a sensitive study of how we speak. ${ }^{36}$

Thus, according to Dworkin, both John Austin ${ }^{37}$ and H.L.A. $\mathrm{Hart}^{38}$ insist that their positivist theories of law are really only explications of the criteria to which we all implicitly refer when we use the word "law." The linchpin of the plain fact view of law is the assumption that there are shared grounds or criteria implicit in the very use of the word "law" that can be made explicit. It is precisely this assumption that Dworkin challenges through his examples of the case law.

In the McLoughlin ${ }^{39}$ case, for instance, the judges were confronted with the issue of whether a person not on the scene of the accident could recover for the personal injury caused to her by the shock of seeing in the hospital, hours after the accident, how seriously her family

${ }^{36}$ Id. at $31-32$.

${ }^{37}$ See id. at 32 ("John Austin. . . said he was explicating the meaning of law"). See supra note 7 and accompanying text.

ss See id. at 34 (Hart argued "propositions of law are true" if they have "community acceptance"). See supra note 8 and accompanying text.

s9 McLoughlin v. O'Brian, 2 All E.R. 298 (1982). 
had been hurt. ${ }^{40}$ The judges of the House of Lords reached a unanimous decision to reverse the Court of Appeals' refusal to extend liability, but they diverged on the state of the law. "Several [judges] said that policy reasons . . . might in some circumstances be sufficient"41 to justify a judge's refusal to expand liability, but those circumstances were not controlling in this case. ${ }^{42}$ Two of the Lords, on the other hand, argued that policy reasons could not be used to deny entitlement unless the legal principles assumed in the earlier cases did not apply. ${ }^{43}$ They disagreed, in other words, about what it meant to follow precedent in this case. Dworkin attempts to show that the judges were not "keeping their fingers crossed," really knowing all the while that they were arguing about morality as they pretended to disagree about the state of the law. ${ }^{44}$ Nor was the basis for their argument reducible to the danger inherent in using a word like "law," whose complexity of definition may keep its criteria for usage from being easily fixed at the boundaries. Instead, Dworkin argues that there was a fundamental argument about the very criteria for the use of the word "law."45 The conclusion he believes should follow from McLoughlin, and from his other sample cases is that

[t]he various judges and lawyers who argued our sample cases did not think they were defending marginal or borderline claims. Their disagreements about legislation and precedent were fundamental; their arguments showed that they disagreed not only about whether Elmer should have his inheritance, but about why any legislative act, even traffic codes and rates of taxation, impose the rights and obligations everyone agrees they do; not only about whether Mrs. McLoughlin should have her damages, but about how and why past judicial decisions change the law of the land. They disagreed about what makes a proposition of law true not just at the margin but in the core as well. ${ }^{46}$

In other words, Dworkin argues that the plain fact view of law does not correspond to our experience of actual legal debates. When we read the McLoughlin case we sense immediately that Dworkin is right when he insists that the judges were disagreeing about what makes a

10 See id. at 301; R. Dworkin, supra note 20, at 24.

4 McLoughlin, 2 All E.R. at 302.

12 See R. Dworkin, supra note 20, at 27-28.

43 See id. at 28.

14 Id. at 39.

45 See id. at 39-42.

48 Id. at $42-43$. 
proposition of law true and, therefore, about the intrinsic criteria inherent in the meaning of the word "law." Dworkin is refuting Austin's assertion that, when he defines the truth conditions of law as the correct reporting of the past command of the person or group who occupies the position of sovereign in that society, he is only accurately reporting what law is for us. ${ }^{47}$ Austin, in other words, is defeated by the terms of his own defense, that his project successfully elaborates the criteria inherent in our everyday use of the word "law."48 Dworkin, in spite of his challenge to Austin, still accepts that an adequate explanation of legal interpretation must match, even if only imperfectly, the actual practice of judges and lawyers. His argument is that the plain fact view of law is undermined by its own claim that it does match this experience when it clearly does not:

If legal argument is mainly or even partly about pivotal cases, then lawyers cannot all be using the same factual criteria for deciding when propositions of law are true and false. Their arguments would be mainly or partly about which criteria they should use. So the project of the semantic theories, the project of digging out shared rules from a careful study of what lawyers say and do, would be doomed to fail. ${ }^{49}$

We can also reach Dworkin's conclusion with the help of the insight of the later Wittgenstein. For Wittgenstein, it is precisely because we appeal to communitarian standards in order to make sense that we cannot determine the entire repertoire of community standards. ${ }^{50}$ The philosopher cannot stand outside the relevant language game making explicit the very boundaries and practices that were only implicitly realized in the usages of ordinary people. The rules are not there for one to know, for the rules themselves are only given meaning in and through our participation in the relevant language games. It is not, however, that there are no rules in law, but rather that it is interpretation that gives us the rules, and not the rules that give us the ground for interpretation. The later Wittgenstein teaches us that there can be no "ground" for interpretation. ${ }^{51}$

Just because there is no ground for legal interpretation does not necessarily mean that we are thrown back into nihilism. We can now

17 See id. at 32-33.

48 See id.

40 Id. at $42-43$.

so See Philosophical Investigations, supra note 11, at 220.

31 See id. at 224. 
see how the insight of the later Wittgenstein also bolsters Dworkin's argument against external skepticism. External skepticism, as Dworkin defines it, is the position that concludes that, because we can never get outside our language game, we can never definitively provide ourselves with objective criteria for judging competing interpretations, whether in law or in art. ${ }^{62}$ For example, Dworkin argues that one very convincing interpretation of Hamlet is that it is about delay. Dworkin explains the external skeptic's response to whether that interpretation should be accepted:

An "external" skeptic might say, "I agree with you; I too think this is the most illuminating reading of the play. Of course, that is only an opinion we share; we cannot sensibly suppose that Hamlet's being about delay is an objective fact we have discovered locked up in the nature of reality, 'out there' in some transcendental metaphysical world where meanings of plays subsist.",63

Dworkin's correct assertion is that external 'skepticism relies implicitly on the very metaphysical position it attempts to refute, for the skeptic cannot know that there is no beyond or metaphysical reality unless somehow or another she gets outside her language game. ${ }^{54}$ Dworkin also argues that we do not need an appeal to "objective" criteria in order to assess competing interpretations; we can instead rely on shared standards of literary interpretation. ${ }^{\text {55 }}$

For Dworkin, there is another kind of skepticism that more accurately describes the skeptical practice within American legal circles. Dworkin refers to this second kind of skepticism as internal skepticism. Dworkin defines internal skepticism as follows: "Internal skepticism ... relies on the soundness of a general interpretive attitude to call into question all possible interpretations of a particular object." $"$ The internal skeptic is, in other words, a person who calls into question the value of a particular social practice. The very process of calling a particular practice into question is done through an appeal to the values

52 See R. DwORkin, supra note 20, at 79-80, 83.

ss Id. at 78 .

54 See id. at 83-85. This is exactly the lesson of the later Wittgenstein. It is precisely because we are "inside" our form of life that we cannot know that the beyond is not "there"-an insight that legitimates Wittgenstein's lifelong interest in mysticism, if such an interest needs to be legitimated. There is, then, no rigid divide between the immanent and the transcendent.

os See id. at 80-83.

sB Id. at 78-79. 
and standards of criticism available to us within our form of life.

Once again he relies on, instead of scorning, the idea that some social practices are better than others; he relies on a general attitude about social value to condemn all the interpretations . . o offered by his fellows. He assumes his general attitudes are sound and their contrary ones wrong. ${ }^{.7}$

The internal skeptic operates within the established social practices, even if his operative stance is one of radical questioning. Dworkin also attempts to argue against either individualist or collectivist versions of subjectivism in interpretation, that the practices we interpret are actually "there." For Dworkin, even the internal skeptic relies for the power of his critique on an externalized, objectified practice. Interpretation, in other words, is not just a matter of the community or of the individual playing with itself.

Social practices are composed, of course, of individual acts. Many of these acts aim at communication and so invite the question, "What did he mean by that?", or "Why did he say it just then?" If one person in the community . . . tells another that the institution requires taking off one's hat to superiors, it makes perfect sense to ask these questions, and answering them would mean trying to understand him in the familiar way of conversational interpretation. But a social practice creates and assumes a crucial distinction between interpreting the acts and thoughts of participants one by one, in that way, and interpreting the practice itself, that is, interpreting what they do collectively. It assumes that distinction because the claims and arguments participants make, licensed and encouraged by the practice, are about what it means and not what they mean. ${ }^{58}$

Interpretation is an interaction between the participants in the practice and the actuality of the practice itself. To demonstrate his understanding of this relationship, Dworkin uses the example of the established practices of courtesy. Dworkin argues that, as we all know, there are certain practices of courtesy that are mechanically accepted because the norms they embody are so deeply internalized that they are not challenged. ${ }^{58}$ As the norms of the society begin to change, these

${ }^{69}$ See id. at 47. 
established practices of courtesy are called into question. ${ }^{60}$ Think for example of the long-established practice of having men open doors for women; it was questioned and reinterpreted by the feminist movement of the 1970s. Dworkin's argument is that the questioning of a practice takes place within the context of the practice itself, because within the conduct of that practice are underlying purposes that are also being expressed. ${ }^{61}$ When we begin to reinterpret the practice, we do so on the basis of an immanent critique which suggests that the purposes embodied in the practice are no longer adequately expressed in the current conduct of the practice. According to Dworkin, during these periods of social change in which reinterpretation of established practices is widely understood to be necessary, we develop an attitude toward the old rules that has two components:

The first is the assumption that the practice of courtesy does not simply exist but has value, that it serves some interest or purpose or enforces some principle-in short that it has some point-that can be stated independently of just describing the rules that make up the practice. The second is the further assumption that the requirements of courtesy-the behavior it calls for or judgments it warrants-are not necessarily or exclusively what they have always been taken to be but are instead sensitive to its point, so that the strict rules must be understood or applied or extended or modified or qualified or limited by that point. Once this interpretive attitude takes hold, the institution of courtesy ceases to be mechanical; it is no longer unstudied deference to a runic order. People now try to impose meaning on the institution-to see it in its best light-and then to restructure it in the light of that meaning. ${ }^{62}$

Dworkin is arguing both that there are "real" practices that are actually "there" for us to interpret, and that these practices institutionalize purposes open to reinterpretation. The interpretive attitude does not need to rely on outside normative principles, but can instead base its reinterpretation on an immanent critique. It is important to note that, for Dworkin, it is not critique that is fundamental, but reconstruction. The interpreter is not only to imagine how the practice might be established differently, she is to reconstruct what that practice actually meant in the past. The interpreter, in other words, is to put on her

\footnotetext{
${ }^{60}$ See id.

B1 See id. at 48-49, 122.

${ }^{62}$ Id. at 47.
} 
rose-colored glasses so that she can see what the practice has meant in the past once it is put in its best light.

Dworkin also argues that the practice of seeing the world through rose-colored glasses is relevant to how we understand the role of intent in legal interpretation. Citing Hans George Gadamer for the proposition, Dworkin shows us that we must always imply an intent when we interpret, but only in a very specific sense.

I mean that an interpretation is by nature the report of a purpose; it proposes a way of seeing what is interpreted-a social practice or tradition as much as a text or painting-as if this were the product of a decision to pursue one set of themes or visions or purposes, one "point," rather than another. This structure is required of an interpretation even when the material to be interpreted is a social practice, even when there is no historical author whose historical mind can be plumbed. ${ }^{63}$

When we posit intent we construct the best possible reading in light of what would most fully realize the implied purpose of the practice. When the critic interprets the intent of the author or painter involved, she necessarily brings her own sense of artistic standard to the project; that is what gives her the vantage point to argue that the ambitions of the author would be best realized if her work were read in this particular way. For Dworkin, the engagement of the interpreter's own interpretative stance does

not mean that [the] use of artistic intention is a kind of fraud, a disguise for the interpreter's own views. For the imagined conversation has an important negative role: in some circumstances an interpreter would have good reason to suppose that the artist would reject a reading that appeals to the interpreter. ${ }^{84}$

Following Gadamer, Dworkin insists that the process of reconstructing intent is dialogical precisely because the author's exact psychological intention cannot be plumbed. ${ }^{65}$ Dworkin wants to make it clear that he has abandoned the crude conscious-mental-state view of intention, ${ }^{66}$ which is why he is able to argue that we construct an intent even when there is no specific author.

\footnotetext{
es Id. at 58-59 (citing H. Gadamer, TruTh AND Method (1975)).

64 Id. at 57.

es See id. at 55.

${ }^{66}$ See H. Gadamer, Truth and Method 192-214 (1975).
} 
In both the examples of how we interpret the practice of courtesy and of how we construct intent, Dworkin shows that it is possible to put on rose-colored glasses when we interpret because the very social practices, legal texts, or works of art to which we give our attention embody purposes and intents that provide the standpoint for reconstruction. When we reconstruct, we do so from within the practice, not by imposing outside principles upon it. Dworkin's central point is that these practices contain purposes, and that an adequate interpretation must be "true" to those purposes. ${ }^{67} \mathrm{~A}$ community, which is made up of social practices that embody purposes, cannot then be reduced to a mere de facto reality. The act of interpretation itself demands that we examine the purposes of our social reality.

It is important to note a tension in Dworkin's own understanding of the inherent reconstructive aspect of the interpretive enterprise. Since Dworkin separates law from morality and has no conception of collective ethics, he must also divide interpretation, even reconstructive interpretation, from evaluation based on the "should be." Dworkin, in other words, cuts himself off from the conclusion his own insight demands: interpretation necessarily includes evaluation and the appeal to the "should be" as the basis for the justification of legal principle.

In his remarks on the distinction between justice and law we are once again confronted by this tension in Dworkin between the "is" and the "should be." As Dworkin explains:

Law is also different from justice. Justice is a matter of the correct or best theory of moral and political rights, and anyone's conception of justice is his theory, imposed by his own personal convictions, of what these rights actually are. Law is a matter of which supposed rights supply a justification for using or withholding the collective force of the state because they are included in or implied by actual political decisions of the past. ${ }^{68}$

In other words, justice is prospective and, like morality, personal to the individual. Justice cannot be other than personal to the individual as long as Dworkin does not develop a conception of our collective ethics as they are embodied in law. The tension in Dworkin's own conception of the ethical status of legal principle is also reflected in his uneasiness with the prospective aspect of interpretation as reconstructive. Dworkin understands that the judge cannot just describe what the

${ }^{67}$ See R. Dworkin, supra note 20 , at 55-56.

88 Id. at 97 . 
law is when she announces her decision; she must also enunciate the principle or purpose embodied in the law governing a particular case. But since Dworkin maintains that legal interpretation is about what the law is and not what about what it should be, it is difficult to understand exactly what is entailed in legal reconstruction of principle. Dworkin, in other words, wants to insist that we are held to the past of precedent and that even so, the appeal to the "is" or "was" of law always carries within it reconstructive potential. I will suggest that we can only make sense of the reconstructive potential of the "is" of law if we understand how the indeterminacy of legal principle unleashes the "should be" in the "might have been" in the reevaluation of our recollective ethics, and deconstructs the radical divide between the "is" and the "ought" that Dworkin always maintains.

\section{B. Three Views of Community}

Despite the tension in his work just described, Dworkin's recognition that the "is" of the community has inherent purposes leads him to conclude that we must determine which of the three competing theories of interpretation he discusses most forcefully embodies the purposes we associate with the rule of law. Dworkin contrasts his own view of law as integrity with conventionalism and legal pragmatism. Each of the three views of interpretation implies a view of community and an understanding of the purpose of a legal system.

Before we begin to discuss the different kinds of community implied in these three approaches to interpretation, we must counter a preliminary objection. That objection is that the very conception of community as an embodied set of practices, and therefore as a social reality, undermines one of the central insights of liberal contractualist political theory, the denial of the reality of the community in the name of individual liberty. Such theories advocate that the only legitimate restrictions that can be imposed by the state are those to which the individual would at least hypothetically agree on the basis of individual choice. ${ }^{69}$ The state, in other words, can legitimately defend its claim of obligation from its citizens only if such obligation can be justified on some theory of contractual consent.

Dworkin understands that he must counter contractualist theories of justice and of legal obligation more generally. Does such a theory of contractual consent really converge with our experience of how and

${ }^{68}$ See, e.g., J. RAwLS, A THEORY OF Justice 11-22, 118-92 (1971) (presenting "a conception of justice which generalizes and carries to a higher level of abstraction the familiar theory of the social contract"). 
why we are obligated to our legal community? Dworkin thinks not:

The connection we recognize between communal obligation and choice is much more complex and more a matter of degree that varies from one form of communal association to another. Even associations we consider mainly consensual, like friendship, are not formed in one act of deliberate contractual commitment the way one joins a club, but instead develop through a series of choices and events that are never seen, one by one as carrying a commitment of that kind. ${ }^{\mathbf{7 0}}$

Nevertheless, Dworkin also recognizes that communal obligation rests on the establishment of certain preliminary conditions. Even if these conditions cannot be identified with contractual justice, obligation does not arise simply because the community exists. Dworkin identifies four components of the attitude the group must have toward its members if "fraternal" obligation is to hold. First, the members must view the obligations that stem from belonging to the group as special, "holding distinctly within the group, rather than as general duties its members owe equally to persons outside it." ${ }^{\text {"71 }}$ Second, the individual members must accept that their obligations are personal in the sense "that they run directly from each member to each other member, not just to the group as a whole."72 Third, the obligations incurred by the individual group must be seen

as flowing from a more general responsibility each has of concern for the well-being of others in the group; they must treat discrete obligations that arise only under special circumstances, like the obligation to help a friend who is in great financial need, as derivative from and expressing a more general responsibility ... throughout the association. $^{\text {.3 }}$

Fourth, the members of the group must believe that there is equal concern for all members, even within a hierarchical structure. ${ }^{\mathbf{7 4}}$

Dworkin realizes that the four conditions he describes give only an abstract sketch of community. Every community is a specialized set of historical practices developed within a specific context. But Dworkin also reminds us that the mere recognition that certain conditions must

${ }^{70} \mathrm{R}$. Dworkin, supra note 20, at 197.

71 Id. at 199.

${ }^{2}$ Id.

${ }^{73}$ Id. at 200.

74 See id. at $200-01$. 
be met in order for an obligation to hold does not return us to a contractualist understanding of community.

[Nothing] in the four conditions contradict[s] our initial premise that obligations of fraternity need not be fully voluntary. If the conditions are met, people in the bare community have the obligations of a true community whether or not they want them, though of course the conditions will not be met unless most members recognize and honor these obligations. It is therefore essential to insist that true communities must be bare communities as well. ${ }^{75}$

The conditions necessary for a bare community do not define the principled practice embodied in the rule of law in a democratic society. For Dworkin, the norm or value embodied in the modern conception and practice of the rule of law is integrity. "Law insists that force not be used or withheld, no matter how useful that would be to ends in view, no matter how beneficial or noble these ends, except as licensed or required by individual rights and responsibilities flowing from past political decisions about when collective force is justified."76 And how should one understand law as integrity?

Law as integrity asks judges to assume so far as this is possible, that the law is structured by a coherent set of principles about justice and fairness and procedural due process, and it asks them to enforce these in the fresh cases that come before them, so that each person's situation is fair and just according to the same standards. ${ }^{77}$

Integrity, then, is not just consistency in fact with precedent, but consistency in principle with the standards embodied in the past cases. When the judge vindicates one interpretation over another she not only gives meaning to her interpretation, she also claims for her interpretation a principled rightness. She is not only claiming that her specific decision in this case is both consistent with precedent and with the facts of the case, but also that her decision ought to carry authority for the principle she has enunciated. If another judge is to disagree with her decision, that other judge must do so on the basis that the principle originally enunciated is an incorrect statement of principle. For Dworkin, then, the process of judging always demands that the judges speak to the principles that have been enunciated in the cases, not just to the

${ }^{76} \mathrm{Id}$. at 93.

77 Id at 243. 
meaning of the sentences in which the principles are laid out. For Dworkin, rational coherence is an ideal that inheres in this very process of enunciating principles.

Is integrity only consistency (deciding like cases alike) under a prouder name? That depends on what we mean by consistency or like cases. If a political institution is consistent only when it repeats its own past decisions most closely or precisely in point, then integrity is not consistency; it is something both more and less. Integrity demands that the public standards of the community be both made and seen, so far as this is possible, to express a single, coherent scheme of justice and fairness in the right relation. An institution that accepts that ideal will sometimes, for that reason, depart from a narrow line of past decisions in search of fidelity to principles conceived as more fundamental to the scheme as a whole. ${ }^{78}$

Yet even so, anyone who accepts law as integrity must also accept "that the actual political history of his community will sometimes check his other political convictions in his overall interpretive judgment."79

When our officials act in their official capacities, they are the voice of the community. "Judicial opinions formally announced in law reports, moreover, are themselves acts of the community personified that, particularly if recent, must be taken into the embrace of integrity."80

The striving for rational coherence is an essential aspect of Dworkin's conception of the community personified. The state is to speak with a single voice, as if it were literally a personality. To speak in different voices would be to undermine the personification of the community, as it would also supposedly defeat the community's claim to authority as a community of principle. For Dworkin,

a judge who accepts integrity will think that the law it defines sets out genuine rights litigants have to a decision before him. They are entitled, in principle, to have their acts and affairs judged in accordance with the best view of what the legal standards of the community required or permitted at the time they acted, and integrity demands that these standards be seen as coherent, as the state speaking with a single voice. ${ }^{81}$

${ }^{79} \mathrm{Id}$. at 255.

${ }^{80} \mathrm{Id}$. at 248 .

81 Id. at 218. 
Dworkin defines his personified community of principle in the following way:

Members of a society of principle accept that their political rights and duties are not exhausted by the particular decisions their political institutions have reached, but depend, more generally, on the scheme of principles those decisions presuppose and endorse. So each member accepts that others have rights and that he has duties flowing from that scheme, even though these have never been formally identified or declared. Nor does he suppose that these further rights and duties are conditional on his wholehearted approval of that scheme; these obligations arise from the historical fact that his community has adopted that scheme, which is then special to it, not the assumption that he would have chosen it were the choice entirely his. In short, each accepts political integrity as a distinct political ideal and treats the general acceptance of that ideal, even among people who otherwise disagree about political morality, as constitutive of political community. ${ }^{82}$

According to Dworkin, the first of his competing approaches to law as interpretation, conventionalism, must be rejected in part because it cannot offer a view of community that justifies its claim to authority. ${ }^{83}$ The understanding of community offered by conventionalism is what Dworkin calls the "rulebook" view of community, a view consistent with the conventionalist approach to interpretation more generally. ${ }^{84}$ Dworkin defines conventionalism in the following manner: "Conventionalism holds that legal practice, properly understood, is a matter of respecting and enforcing these conventions, of treating their upshot, and nothing else, as law."8s

The view of community that inheres in conventionalism is one that accepts what Dworkin calls "checkerboard solutions," solutions that allow legal principles to be applied differentially because of the compromises that must take place in any complex society. ${ }^{86}$ As long as the compromise is reached in an appropriate way, in accordance with the conventional rules of the society, the reality that it does not steadfastly apply principle across the board should not lead to its loss of legiti-

82 Id. at 211.

${ }^{83}$ See id. at 210.

84 See id. at 209-10.

88 Id. at 115.

${ }^{86}$ See id. at 210. 
macy. It is the following of the conventionally accepted rules for compromise that is important. As Dworkin explains:

Conventionalism suits people each trying to advance his or her own conception of justice and fairness in the right relation through negotiation and compromise, subject only to the single overriding stipulation that once a compromise has been reached in the appropriate way, the rules that form its content will be respected until they are changed by a fresh compromise. A conventionalist philosophy coupled to a rulebook model of community would accept the internal compromises of our checkerboard statutes, as compromises reached through negotiation that ought to be respected as much as any other bargain. ${ }^{87}$

The pragmatic alternative also leaves us with an inadequate conception of the purposes of our legal community. According to Dworkin, the pragmatist supposes "that members of a community treat their association as only a de facto accident of history and geography, among other things, and so as not a true associative community at all."88 Pragmatism, according to Dworkin, ignores the past in favor of visions of the future. It is not that the pragmatist simply denies principles and rights, but rather that she only refers to them as they are strategically useful for the actualization of her own ideal community. There is no reason for allegiance to her presently existing community if it fails to meet her ideal. She just happens to be a member of this community and no other, and nothing follows from that coincidence. As Dworkin explains, pragmatism requires "that judges do and should make whatever decisions seem to them best for the community's future." What this means is that the pragmatist who operates within our own common law system, with its emphasis on precedent, is a liar, for she appeals to precedent, not in the name of the principles it enunciates but in the name of her own vision. Legal pragmatism, for Dworkin, leaves us with the worst kind of subjectivism in interpretation as each judge attempts willfully to impose her best vision of the future.

\section{G. The Group Novel}

Dworkin believes that there is a second barrier that he must cross in order to successfully develop his own conception of law as integrity.

87 Id.

88 Id. at 209.

${ }^{89} \mathrm{Id}$. at 95. 
He wants to show us that consistency with precedent is indeed possible. $\mathrm{He}$ defends the position that there are inherent constraints in the interpretation of social and legal reality. To do so, he uses the example of the group novel. ${ }^{90}$ For Dworkin, the past embodied in precedent weighs on the judge in the same manner that the work of those who have written before has shaped a group novel, so that each new writer is progressively more constrained as the novel takes shape. Dworkin is trying to show us the reality of the group project as it develops. According to Dworkin, there is really "something there," which has arisen in and through precedent and which acts as an effective constraint on the community of interpreters. ${ }^{91}$

Deciding hard cases at law is rather like this strange exercise. The similarity is most evident when judges consider and decide "common-law" cases; that is, when no statute figures centrally in the legal issue, and the argument turns on which rules or principles of law "underlie" the related decisions of other judges in the past. Each judge is then like a novelist in the chain. He or she must read through what other judges in the past have written not simply to discover what these judges have said, or their state of mind when they said it, but to reach an opinion about what these judges have collectively done.....$^{92}$

Although the novel is the result of the creative, subjective efforts of individuals, what they create is objectified as the novel, which in turn acts as a constraint on their own project. The tradition that has been objectified is the basis for the possibility of integrity. If we are to be faithful to the rule of law, there must be something "there" to which we may be faithful.

\section{The CRItique of Dworkin}

\section{A. The Allegory of Integrity: The Fish/Dworkin Debate}

Dworkin's claim that the accumulation of precedent in a given area of law creates something "there" that can provide constraints on interpretation has been challenged by Stanley Fish, among others, on the basis that there is an ambiguity in the status of whatever it is that arises from the accumulation of precedent. Fish's argument against

\footnotetext{
${ }^{80}$ See id. at 229.

${ }^{91}$ See id. at 229-32.

82 Dworkin, Law as Interpretation, supra note 16, at 542.
} 
Dworkin, however, is that in spite of communitarian constraint, the "chain gang" cannot provide a determinate barrier against the reinterpretation of the entire project. ${ }^{93}$ As Fish correctly argues, it is not necessarily the case that each new writer in the group is progressively more constrained, because reinterpretation of the overall project is always possible. ${ }^{94}$ Even so, Dworkin is not to worry about the danger of innovation and irresponsible subjectivism:

The point is one I have made before: it is neither the case that interpretation is constrained by what is obviously and unproblematically "there," nor the case that interpreters in the absence of such constraints, are free to read into a text whatever they like (once again Dworkin has put himself in a corner with these unhappy alternatives). Interpreters are constrained by their tacit awareness of what is possible and not possible to do, what is and is not a reasonable thing to say, what will and will not be heard as evidence, in a given enterprise; and it is within those same constraints that they see and bring others to see the shape of the documents to whose interpretation they are committed. ${ }^{95}$

93 See Fish, supra note 16, at 552-55.

o4 See id.

9s See id. at 562. The "shape of the documents," in other words, is only a matter of convention. The attention to certain documents in law is also only a matter of convention. See S. FISH, supra note 17, at 301-04 (the "shape," or genre of a work does not determine which interpretations are appropriate, since "organization, style, and figure are interpretive facts"). What is "there" is present because it is there for us. And yet, according to Fish, the community is no more collectively free to restructure practices than is the individual to change her habits of life. The error of thinking that the community is free to restructure its traditions just because its members have recognized the conventional "nature" of meaning is what Fish calls anti-foundationalist hope. Id. at 304-08.

We might summarize the difference between Dworkin and Fish in this way: Dworkin emphasizes the precedence of the past over the present, which permits the idea that constraints in interpretation are differential and cumulative, since the past is constitutive of the present. It is interesting to note that Dworkin is not always clear about the constitutive role of the past. At times, he also seems to indicate that the past is only there "for us" in the present. "Law as integrity, then, begins in the present and pursues the past only so far as and in the way its contemporary focus dictates." $R$. DwoRkin, supra note 20, at 227 . Of course, there is a simple truth to this assertion. It can be understood to mean only that the judge addresses the past as it is relevant to the case at hand. The crucial factor to be determined is the role that the past embodied in tradition plays in shaping the very way we frame the question in "the present." I am arguing that Fish implicitly rejects the constitutive power of the past over the present, and that Dworkin himself sometimes vacillates on this point. Derrida brilliantly demonstrated the constitutive power of the past at the same time that he has also shown why the "present" evaporates as an interpretative category, leaving us instead with the promise of the future implicit in a past never capable of being made present to itself. See J. Derrida, Memoirs for Paul deMan 58-60 (1986). Derrida's understanding 
According to Fish, we cannot help but be consistent with precedent, because the only meaning given to the past is that which those in power in our community have construed from it. In this sense consistency is no longer an issue; the only meaning of the past is what it is for us now. Thus, the real disagreement Fish has with Dworkin has less to do with the debate over the possibility of consistency in interpretation than with Fish's rejection of Dworkin's argument that the "is" of the modern legal community incorporates principles that restrain the brute exercise of power. For Fish, since law is only power, there can be no appeal to "the rule of law" as a check on power. Integrity, in other words, is a sham. According to Fish, the very notion of appealing to a legal principle such as integrity is outdated for two reasons: first, we cannot rationalize the actual, complex practice of law into a legal principle such as integrity, which can then guide the judge in her decisions; second, the very appeal to an ideal denies the anti-foundationalist truth that all "there is" are the enforced institutionalized conventions and, therefore, the very idea of an appeal to principle is necessarily impossible, because it reinstates a transcendental viewpoint.

\section{B. Dworkin's Own Divide Between the "Is" and the "Should Be"}

It is important to note, here, that both Fish and Dworkin appeal to "existing" community as the basis for interpretation. In this sense, both writers downplay the possibility of radical transformation based on immanent critique of the community that reflects the unrealized "should be" implicit in the "might have been." The difference between the two can not simply be reduced to the difference between a positivist and an anti-positivist, because Dworkin, too, relies on a description of the reality of what the law is or was. The difference has to do with the content of the description of the legal community.

For Dworkin, the existing community contains principles and it is to these established principles that we turn for the basis for reinterpretation. But again, I must stress that this appeal to established principle

of the time frame of interpretation separates him from Dworkin and Fish. Fish, on the other hand, understands communitarian restriction to be always present, but in the same way for each new writer in the group novel.

It is to Dworkin's credit that he recognizes the temporal dimension of an appeal to an already established, institutionalized community as the basis for shared meaning and, more importantly, for shared values. For Fish, on the other hand, we are all forever locked into the eternal present of the presence of our interpretive context. We are in the "here and now" and we can be nowhere else, for the past only exists for us as we interpret it, and the future is only there as a continuation of what is now. This explains why, for Fish, law is only an expression of the present power of an actual existing community. See S. FISH, supra note 17, at 303-04. 
does not imply a call to realize the "should be" in the "might have been" of an indeterminate past. Dworkin's group novel attempts to render the past more conceptually determinate that it ever can be. My criticism of Dworkin, however, should not be taken to mean that there is no weight to the past whatsoever. Indeed, ironically it is Dworkin who avoids the full material weight of the past whenever he puts on his "rose-colored glasses." Without his group novel to counter indeterminacy, Dworkin sees no way to avoid the slide down the slippery slope into his opponent, legal pragmatism. Battling with what he takes to be pragmatism leads Dworkin to insist that when we reinterpret precedent we are still constructing what the law actually was (even if in its best light) and not referring to what it might have been if we had accepted a different interpretation of the principles embodied in precedent. ${ }^{96}$ By so doing, Dworkin creates a paradox he cannot successfully resolve within the framework of law as integrity.

Here again, Dworkin seems to want to have it both ways. In his refutation of the semantic sting, ${ }^{97}$ Dworkin implicitly recognized the validity of the Wittgensteinian insight that the criteria for word usage cannot be rendered fully determinate. At the same time, Dworkin also wants to insist that there is enough conceptual determination of established legal principle to preserve the divide between the reliance on the "is" of law as the basis for reinterpretation and an appeal to the impermissible "should be" of the pragmatic vision. ${ }^{98}$

${ }^{96}$ See supra notes 88-89 and accompanying text.

97 See R. Dworkin, supra note 20 , at $45-46$.

88 The realization that an appeal to interpretive context cannot cement meaning does not undermine Dworkin's view of coherence and consistency-in-principle as normative ideals. In truth, Dworkin does not need the group novel example to make his central point that there is something "there" for the judge to follow-which indeed she should follow-other than her own personal opinion. His insistence that our practices may always be reinterpreted on the basis of underlying principles undercuts his group novel as exemplifying a past set of cumulative constraints preventing the reinterpretation of the entire project. In other words, he does not need to establish the "objectivity," in any strong sense of the word, of the positive meaning of precedent. As Dworkin himself has put it, the constraint of the group novel "is not the constraint of external hard fact or of interpersonal consensus. But rather the structural constraint of different kinds of principle within a system of principle, and it is none the less genuine for that." R. Dworkin, supra note 20, at 257. As Dworkin now seems to realize, he can meet the requirements of his own project with an appeal to the social reality of the norms embodied in law, other than the individual judge's opinion, but which a judge must at least confront when she makes a decision. The inevitable confrontation with embodied social norms does not mean that she cannot reinterpret them, because the definition of the norms themselves can never be fully determinate. Richard Posner is right, then, to insist that the appeal to an interpretive context cannot be dispositive of legal dispute once the competing tendencies within our own sittlich commitments have been articulated. Posner, The Decline of Law as an Autonomous Discipline: 1962-1987, 100 HARV. L. REV. 761, 766-77 (1987). An economic analysis is now part of our legal 
I would argue instead that when we reinterpret or reconstruct a line of precedent, we are recovering what "might have been"日9 if we had understood the embodied principles or norms differently. Yet, to argue that we reinterpret the law from the standpoint of what "might have been" if we had realized an alternative potential inherent in our expressed principles, is not to accept the proposition that we simply pick the countervailing norms out of a hat. This theory still recognizes that the future of meaning arises out of the reinterpretation of the past; the "might have been" is what supplies the "should be." When we suggest that precedent conflicts with our current conception of legal principles and when we insist that precedent should be interpreted based instead upon a reevaluation of embodied norms, we are not simply making things up.

Dworkin's uneasiness stems from his attempt to divide theoretical disagreements about what the law is from contentions about what the

tradition, if the word "tradition" is broadly construed. Of course, when I state that economic analysis is part of our tradition, I do not defend the position that law is an autonomous discipline that can be rigidly divided from other disciplines. I largely agree with Posner's analysis. Id. There he argues that the demise of consensus within the legal community as to the best solutions to difficult problems of justice inevitably leads to the relevance of "outside" theories to legal discussion. Id. at 766. My only slight disagreement is that in other countries appeals to economics, as well as to ethical theories, have been considered part of jurisprudence and, therefore, as "inside" the legal discipline. If the judge reinterprets within her judicial role, she must do so on the basis of these indeterminate social norms and not solely on the basis of her own personal philosophy, although this too will be implicated. That is, she must speak as a judge and not as an individual.

Fish is much more aware than Dworkin of the contribution of "post modern" philosophy to the breakdown of any appeal to an established "is," which is why our appeal to convention boils down to his insistence "that might makes right." Fish, in his view of law, returns us to Austin. Whatever the state can enforce as its brute command, it has the "right" to do. There is no right above and beyond power. Here we are returned to an ironic concurrence between Fish and Dworkin. In Fish, the community is reduced to the will of those individuals in power. In Dworkin, the community is also reduced to individuals who have the wisdom of judicial beings. But in both, Fish and Dworkin, the community is reduced to the "reality" of individuals who either exercise their might or who identify the right with what they say it is. Both begin with an appeal to community but leave us with the enunciation of individuals. They both need to appeal to a pregiven community but have no way to account for its reality.

For Fish, in other words, anti-foundationalism leaves us with those in power.

${ }^{89}$ Again, we can see the relevance of Posner's point that appeals to context tell us very little, for context always includes the might have been. See id. at 773, 777. One way of understanding law and economics as an interpretive intervention in American law is that it shows us what might have been if we had consistently applied economic principles to the case law in a particular doctrinal area. Under the guide to interpretation I am offering here, Posner's argument can be taken to mean that the appeal to convention can never preclude competing interpretations of the past through the reevaluation of what might have been, and that this reevaluation, particularly in a time of declining consensus, demands the inspiration of competing theories of justice and the role of law. 
law should be. In fact, if we accept Dworkin's central insight that legal interpretation always involves the elaboration of principle, then, whenever we enunciate what the law is, we are also implicitly stating that this is the way it should be, based on an evaluation or a reevaluation of what might have been as well as of what has been. An examination of the "might have been" is demanded if we are to deliver the best possible justification of legal principle. There is no need to fear the implicit appeal to a "should be" as inherent in the evaluation and justification of principle, as long as we recognize that the "should be" does not result from the artificial imposition of an outside moral viewpoint. We can argue, instead, that there is an authorization of "should be" inherent in the law's stated principles and purposes that belies the actual outcome in legal decision, enforced by and perpetuated in precedent.

\section{The Danger of Rose-Colored Glasses}

Dworkin's uneasiness that any appeal to the should be constitutes the imposition of an external standard of justice or morality underlies his method of interpreting precedent through rose-colored glasses. ${ }^{100}$ The methodology directs us to reconstruct a narration of the past in light of the best possible story we can tell of the embodied purposes expressed in a community of principle. Unlike Dworkin's version of the pragmatist, the judge who understands law as integrity must not create interpretive principles, but must only reinterpret in light of principles that are actually "there." Integrity is demanded of us, only insofar as it relates to a past, if a principled past. But what if we find that the past does not live up to principles of justice or fairness? We must break with the past. Dworkin's critique of legal pragmatism insists that the "break" must be disguised as a restatement of what actually was, rather than in the form of a reconstruction of what might have been and what now should be, given our changing interpretations of embodied principle and ethical ideals. Who is more in danger of falling into dishonesty, the so-called legal pragmatist or Dworkin?

\section{The Irreducible Exteriority of Suffering}

There is another danger perhaps even more serious than the potential for dishonesty inherent in disguising the break with the past, although alone this would not seem to promote integrity in the individual judge: the critical evaluation of precedent is undermined. For examnying text.

${ }^{100}$ See R. Dworkin, supra note 20, at 228-32; supra notes 63-67 and accompa- 
ple, consider the actual decision in Brown $v$. Board of Education, ${ }^{101}$ and not the decision as it is cast down to us from the Mount Olympus where Hercules, Dworkin's mythical judge, lives. The plaintiffs in Brown contested the doctrine that allowed states to meet the notion of equality embodied in the fourteenth amendment through segregation as long as the state also provided "separate but equal" facilities for blacks. ${ }^{102}$ The doctrine of "separate but equal" had been enunciated in Plessy v. Ferguson ${ }^{103}$ and faithfully followed by the Court for many years. The question raised by the black schoolchildren in Brown was whether segregation alone, given the racist society such practices implied, made separate facilities inherently unequal. ${ }^{104}$ The Supreme Court unanimously decided in favor of the plaintiffs. ${ }^{105}$ Yet Ghief Justice Earl Warren, who wrote for the Court, did not forthrightly reject the "separate but equal" principle; he relied instead on sociological evidence to show that racially segregated schools could not be equal. ${ }^{106}$ Therefore, he did not explicitly conclude that "separate but equal" was invalid as a principle, but that it could not be realized in practice. ${ }^{107}$ As a result, the "principle" of Plessy was not directly overruled; rather, it was only overruled if it was understood as inconsistent with Brown. ${ }^{108}$

Chief Justice Warren's opinion in Brown may read as if he employed Dworkin's rose-colored glasses in interpreting Plessy. If one examines the principle of "separate but equal" through rose-colored glasses, it could stand not only for the proposition that blacks should be segregated, but also for the proposition that they should be given equal facilities. If we interpret this principle in its best light rather than as a bad excuse for segregating blacks, then we can also argue that because the principle has not been met in this case, we are obligated by the Constitution to prevent the practice of segregation. Chief Justice Warren, thus, strains to follow one reading of Dworkin's integrity by insisting that the rights of the black children in question were established by past precedent, despite the fact that precedent had never enforced those rights. The law of Plessy might have been different given the inherent potential of the fourteenth amendment's open ended language, but unfortunately for the blacks who were deprived of educational opportunities, it was not. The judge's responsibility to mark the failure of the

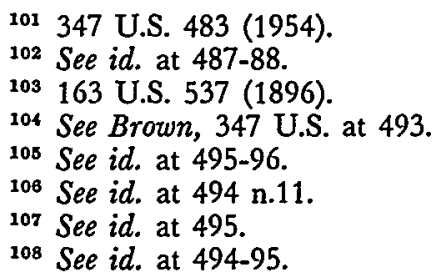


community to live up to a justifiable principle of equality should be understood as an essential part of her task to enunciate a well argued justification for her decision. ${ }^{108}$

${ }^{109}$ From Mount Olympus, Hercules would have us overturn Plessy, "if [it] is really precedent against integration." $\mathrm{R}$. DwORKIN, supra note 20 , at 389 . But is there any doubt that this is what Plessy stood for? Here we have an example of law's ability to make itself "true." That there could have been another reading of the fourteenth amendment is obvious. Yet once this reading was established and enforced, it became the law, and there was no confusion about what the principle "separate but equal" meant, either on the part of lower court judges or on the part of the black schoolchildren and their parents who had to live with the meaning of the decision. On the level of social reality, "separate but equal" was given a concrete meaning as it was enforced by the power of the state: "Keep blacks out of white schools." Therefore, the problem before the Supreme Court was not meaning, but justifying a different view of whether segregation was constitutionally defensible. Theories of justice can be understood as intrinsic to legal analysis once it is understood that the purpose of such analysis involves justification and not mere exposition. See id. at 359-63.

Dworkin understands, of course, that the need to justify a different view of equality was at stake. Hercules examines three different theories of equality that could have informed the reading of the fourteenth amendment (other than the "separate but equal" principle, if it can be dignified as a principle of equality): suspect classifications, banned categories, and banned sources. See id. at 381-87. The examination supposedly permits him to engage these theories in such a way as to

distinguish between the academic and the practical elaboration of each theory; he will ask not only how attractive each theory is in the abstract, as it would be elaborated and applied by a sophisticated political philosopher, but how well each one could be put into practice in a community like his, as a constitutional standard courts could use effectively in deciding what legislation it disqualifies.

Id. at 385.

Hercules ultimately reaches the decision that it is only the first theory of equal protection, suspect classifications, that could possibly justify the result in Plessy and, therefore, it must be rejected. As Dworkin explains, Hercules

will reject the first theory, which denies any special right against discrimination and insists only that the welfare or preferences of each citizen be counted in the same scale, without restriction as to source or character. Perhaps this theory would have been adequate under tests of fairness and fit at some time in our history; perhaps it would have been adequate when Plessy was decided. It is not adequate now, nor was it in 1954 when Hercules had to decide Brown. It gains little support from ideals of political fairness. The American people would almost unanimously have rejected it, even in 1954, as not faithful to their convictions about racial justice.

Id. at 387 .

There are a number of flaws in Dworkin's reasons for rejecting Plessy, and with it the one theory of equal protection-suspect classifications-he uses to justify that result. The first problem is noted in Chief Justice Warren's opinion when he notes that, the "separate but equal" principle cannot be realized in a racist segregationist society, and was therefore neither valid now, see id., nor at the time it was enunciated. But the more significant problem, however, is to determine whose standards of fairness found it "perhaps" adequate at some time. If the standard was adequate for the white judiciary, is that enough to make it an adequate standard? For Dworkin the pronoun "our" undoubtedly excludes black people, suggesting that he is relying here on the conventions of those in power he wants to reject.

Dworkin's final reason for rejecting Plessy is also a problem because it would have 
My point is that we can now see why the judge's failure to exercise the responsibility to critique and to reject explicitly the accepted institutionalized meaning given to past principles may undermine the aspiration to be a community-in-principle. It may better serve the aspiration to be a community-of-principle to condemn a given area of law as irrational and incoherent rather than to pretend that it can be read to meet these standards. By condemning a particular justification of principle the judge replaces not only the principle but also the argument. What is to be gained cannot necessarily be calculated in terms of an actual shift in legal result because the gain is in and through the rhetorical elaboration of the competing principle itself. The rhetoric of a legal opinion constitutes the principle the decision justifies. The socalled "result" in a legal decision, in other words, cannot be separated from the argumentation for that decision as long as we correctly conceive of an opinion not just as a "holding" but as an argument for principles. If the legal opinion is conceived as an argument and justification for principle, then we cannot say that two decisions that develop

been indefensible to the American people in 1954. He argues that the American people, even then, would have almost unanimously rejected Plessy "as not faithful to their convictions about racial justice." Id. After all the violence and turmoil surrounding the racial desegregation of the nation's schools, it is unclear how many Americans, even in 1988, would disagree with the "separate but equal" principle expressed in Plessy. Here, again we are confronted with the significance of Dworkin's incomplete break with positivism. For, to what does Dworkin appeal to defend the rejection of Plessy-the actual conviction of justice of the American people. But it is precisely the actual convictions of white Americans that have stood in the way of desegregation. In order to make his point, Dworkin needs to distinguish between the actual convictions of white Americans and the unrealized "should be" he obviously believes is implicit in the fourteenth amendment. But in order to make this distinction, he would have to deconstruct his own divide between reinterpretation and reevaluation based on an appeal to the "should be."

I agree with Dworkin that segregation is an insult "that must be recognized and removed." Id. at 389 . But when we "recognize and remove it" we are not practicing "faithfulness" to precedent, but rather infidelity in the unrealized "should be" implicit in the ideal. In order to defend his position Dworkin needs to tell us that the law of Plessy should have been different, and that it had the potential to be different, from what it was in Plessy. He is implicitly relying on the should be of the might have been. There is nothing wrong with enunciating a competing principle of equality within our imperfectly embodied norms that would allow us to justify a break with precedent, but integrity demands that we be honest about what we are doing. None of the principles Dworkin offers, however, reaches to the should be of the equal protection clause, which would advocate a principle of antisubordination. It was the systematic subordination of blacks that was the wrong of segregation. Such a wrong cannot be reduced to an insult.

My main point here is not to stress the inherent weakness of the reasons Dworkin gives for rejecting Plessy, for ultimately Hercules decides that he can achieve the result of ruling in favor of the plaintiffs under the theory that: "The plaintiff schoolchildren are being cheated of what their Constitution, properly interpreted, defines as independent and equal standing in the republic; this is an insult that must be recognized and removed." Id. 
different arguments can yield the same result. Law, in other words, cannot be reduced to a cause and effect relationship: the cause, the holding of the case, the effect, the future cases engendered by the holding. What is engendered by the opinion is the justification of principle through argument. If law is both the enunciation and justification of principle, it also entails the explicit critique, and indeed rejection, of past arguments and past principles, if they are found to be unjustifiable. Dworkin's rose-colored glasses undermine the power of criticism, limit our vision of possible reconstructive transformation and potentially ignore the suffering of those affected by the interpretation.

The suffering of others introduces an irreducible exteriority into the process of interpretation. The irreducible exteriority, or the inevitable residue of materiality in history, does not stand completely outside of interpretation. Yet, that being said, there is a limit implicit in the finitude of human life that cannot, with a sweep of the hand, be interpreted away. The example I have just given should make this point with enough force. We can, of course, continuously reinterpret the "separate but equal" principle. But we cannot give back the chance to have an equal education to those who have forever lost that chance. Why should we put our history of racist exclusion into the best light? The real suffering imposed by Plessy can only be respected if we take off our rose-colored glasses and honestly face the harm done by the legal system through the perpetuation of an unjustifiable principle. To use another example, the Jews who lost their families in the Holocaust can reinterpret the meaning of Holocaust but they cannot rewrite their loved ones back into life. ${ }^{110}$ Here again, the last thing we want is for the Holocaust to be interpreted in its best light. It is the irrevocable loss, which cannot be overcome in spite of all of our pleadings and all of our prayers, that provides the limit to interpretation through rosecolored glasses. We can reinterpret, but we cannot will backwards so that the past simply disappears. For all of his insistence on attention to the past, Dworkin does not give enough "weight" to the burden history imposes upon us.

\section{The Time Frame of Legal Interpretation}

However, even if we do not think the rose-colored glasses method can be justified, we can grasp the insight that promotes Dworkin's belief in its validity. His central point is that law inevitably involves

110 See R. Dworkin, supra note 20, at 101-04. 
interpretation.

People say that conservative justices obey the Constitution while liberal ones try to reform it according to their personal convictions. We know the fallacy in that description. It ignores the interpretive character of law. Justices who are called liberal and those who are called conservative agree about which words make up the Constitution as a matter of preinterpretive text. They disagree about what the Constitution is as a matter of postinterpretive law, about what standards it deploys for testing official acts. Each kind of justice tries to enforce the Constitution as law, according to his interpretive judgment of what law is, and each kind thinks the other is subverting the true Constitution. So it is useless as well as unfair to classify justices according to the degree of their fidelity to their oath. ${ }^{111}$

Dworkin recognizes that, because of the normative character of legal interpretation, the judge must engage in the process of reconstruction, which is prospective as well as retrospective. Yet, at the same time, Dworkin wants to insist that the very basis of the rule of law rests on the recognition of the precedence of the past over both the present and the future. According to Dworkin, this insistence on the precedence of the past is what distinguishes law as integrity from legal pragmatism. However, Dworkin is not entirely comfortable with the conclusion that follows from his own recognition that the past of precedent is not simply there for us to recollect, but demands an interpretation if it is to be made present. The rightful conclusion from this insight, which Dworkin cannot draw, is that, without an original anteriority to which we can appeal directly, the law and legal ideals can never simply be revealed. They are always made, in the sense that they enunciate the "should be" inherent in the justification for a given interpretation of the principles and ethical ideals embodied in an area of law. It is not, as Dworkin would have it, that legal interpretation is both prospective and retrospective, but rather that the very process of recollection is itself prospective in that it implies a promise to guide our conduct in the future in accordance with the reevaluation of the "should be" inherent in the "might have been." Yet because we are always in a particular historical context and community, we transform our world here with it.

If Fish is wrong to argue that our historical situatedness in a so- 
cial context that is "always, already" there completely determines the ethical powers of the self, it would also be a mistake to think that the judge, or anyone else, can completely escape from history. We are always in a pre-given context. In this sense, imagination is memory. If we reinterpret Fish, we can see that he is right to insist that none of us is free to step outside of our historical context and just make things up as we go along. Utopians may be dreamers, but the dream is within the social world that has been given to them.

Yet even so, it is the case that the judge, then, never simply exposes the law as she finds it; she posits the very ideals she reads into the law. By so doing, she is remembering the future as she recollects the past. And, of course, she must sign for what she has posited for she can no longer pretend to be the passive carrier of tradition. She does not just perpetuate the past; she, at least in part, makes it what it is to become. It is precisely because the judge does create the past through reconstruction of the "should be" implicit in embodied principle that Dworkin's rose-colored glasses would seem to be justified. But the future orientation of the promise of law implicit in the enunciation of the "should be" found in the reinterpretation of principle does not, in the end, mean that we can pretend that things were completely different than they were. The introduction of the materiality of history through the recognition of the suffering of others belies the pretense that the horror of history can simply be read away.

\section{The Limits of Integrity as a Regulative Ideal: The Need for Justice}

Dworkin's integrity may well demand infidelity to precedent and to the past. This Dworkin recognizes as not the practice of fidelity to the past at all. The question is whether integrity can serve as a principle to justify a break with the past, if it is precisely integrity to the past that is being violated in the name of reconstructed principle. The answer is no.

Consistency-in-principle demands a statement of exactly what the principles are to which we aspire to be faithful, particularly in light of Dworkin's insistence that a break with consistency-in-fact can be justified only by an appeal to consistency-in-principle. ${ }^{112}$ But the only principle Dworkin gives us is integrity, itself a principle that takes us back to the desirability of following precedent, but which cannot justify rup-

112 See id. at 227-28. Once again, we see the crucial need for legal theory in the reconstruction of principle so as to provide the best possible justification for a particular result in doctrine. 
ture with the past. As we have seen, Dworkin's preliminary answer to the seeming dilemma of integrity is that the very process of interpretation is reconstructive because it necessarily implies the construction of an intent or purpose. ${ }^{113}$ To say that an intent or purpose is necessarily implied, however, does not tell us which purpose is to be preferred. Without a clear statement of the purpose or intent, we can hardly have an adequate idea of what it is to which we are being faithful, if it is not just to precedent.

Moreover, Dworkin tells us that we cannot appeal to a theory of justice as the critical basis by which we reconstruct the past, because a theory of justice is either personal or abstract. ${ }^{114}$ Yet he also, at other times, indicates that justice itself is only an interpretive concept. ${ }^{115}$ Why then cannot justice, as much as integrity, serve as an objectified practice rather than as a mere abstract theory or a personal opinion? Dworkin's problem in answering this dilemma stems in part from his characterization of both morality and justice. If morality and justice are both abstract and personal to the individual, then they are by definition not part of the objectified practices of law which are "there" for us to interpret. Because Dworkin's central point is that normative debates about law involve questions of what the law is, and not what the law should $b e$, he believes that he needs to show us that there is a principled practice expressed in the law itself, one that is not imposed by an appeal to an outside value such as justice. But the "cure" to that problem is to try to show that there are also principles of justice inherent in our collective ethics as they are, at least partially, embodied in the law. Without such an appeal to immanent principles of justice, integrity is either vacuous, because it cannot tell us exactly what the principles are by which we can legitimately reconstruct our historical practice and justify a break with precedent, or is itself dishonest, because it smuggles in a conception of justice but disavows it as essential to its interpretive schemata.

Indeed, without a more explicit elaboration of the notions of fair-

113 See id. at 219.

114 See id. at 73-76.

116 As Dworkin himself explains:

[J]ustice is an institution we interpret. Like courtesy, it has a history; we each join that history when we learn to take the interpretive attitude toward the demands, justifications, and excuses we find other people making in the name of justice. Very few of us self-consciously interpret this history the way I imagined the people in my story interpreting courtesy. But we each-some more reflectively than others-form a sense of justice that is an interpretation nonetheless, and some of us even revise our interpretation from time to time.

Id. at 73-74. 
ness and justice that make up a community-of-principle, it is difficult for Dworkin adequately to justify legal obligation, at least in a manner we can accept as compatible with our modern notions of individual freedom. Even if we agree with Dworkin that contractualist theories of justice and community do not explain adequately our own experience of community, ${ }^{116}$ we still need to grapple with the underlying basis for their appeal. Contractualist theories of justice and community continue to be so attractive precisely because they root the legitimation of the state in individual choice and freedom. ${ }^{117}$ Even if that choice is only hypothetical, the rhetoric in which this hypothetical choice is described appeals to the modern commitment to individual freedom.

Dworkin uses the example of the family to demonstrate why it is that the conditions for obligation may fall short of justice and yet still legitimately demand our respect. ${ }^{118}$ There are at least two arguments against the acceptability of his example. The first argument is that-even if we accept that the bare conditions Dworkin describes are sufficient to legitimate our obligation to a small, intimate circle such as the family-those conditions are not enough to obligate us to belong to a large impersonal force such as a state. In our relationship to the state we cannot appeal to love and intimacy as the basis for association. Without in any way downplaying the violence in families, the state's awesome power, combined with its impersonality, still pits us against an institution of a different magnitude.

The second argument, of course, is that the very kind of inequality perpetuated in Dworkin's example of the father resisting his daughter's right to marry is exactly what makes the achievement of justice within the family necessary if so-called intimacy is not to be turned into a bad

${ }^{118}$ See id. at 209-10.

117 See id. at 209.

${ }^{118}$ See id. at 205. But suppose the culture accepts the equality of the sexes, but in good faith thinks that equality of concern requires paternalistic protection for women in all aspects of family life, and that parental control over a daughter's marriage is consistent with the rest of the institution of the family. If that institution is otherwise seriously unjust-if it forces family members to commit crimes in the interest of the family, for example-we will think it cannot be justified in any way that recommends continuing it. Our attitude is fully skeptical and again we deny any genuine associative responsibility and so deny any conflict. Suppose, on the other hand, that the institution's paternalism is the only feature we are disposed to regard as unjust. Now the conflict is genuine. The other responsibilities of family membership thrive as genuine responsibilities. So does the responsibility of the daughter to defer to parental choice in marriage, but this may be overridden by appeal to freedom or some other ground of rights. The difference is important: a daughter who marries against her father's wishes, in this version of the story, has something to regret. She owes him, at least, an accounting, and perhaps an apology, and should in other ways strive to continue her standing in the community she otherwise has a duty to honor. 
excuse for masculine power. ${ }^{119}$ Feminist lawyers, who have argued that standards of justice must be met within the family, have pointed to a long history of accepted abuse in the name of familial obligation. ${ }^{120}$ Even if we decide that, in spite of that history of abuse, we do not want to enforce standards of justice within the family-at least not contractualist standards of justice-we still need to address the danger implicit in Dworkin's own example. It is sobering, after so many heated debates in feminist legal literature, to note Dworkin's seeming lack of awareness of the reasons behind the feminist insistence on justice within the family. Hence, Dworkin's failure to elaborate on the notion of justice leaves him unable to justify this compelled break in legal obligation.

\section{E. Dworkin's Inadequate Conception of Community}

If the serious problem of individual right in a modern community does not get the attention it deserves in Dworkin's work, neither does the analysis of the associative basis for community. Dworkin does not provide us with an account of the inherent sociality of the individual so as to convince us that we actually do belong together with the community. Dworkin's community personified is a projection that magically becomes real as a quasi-subjectivity. Indeed, Dworkin is very serious when he says that we should understand the community as a single author. ${ }^{121} \mathrm{He}$ introduces a very strong associative notion of community only to have it disappear before our eyes. We are left with an account of a judge with integrity, a hero, a super-individual, Hercules. ${ }^{122} \mathrm{We}$ can be pleased that Dworkin offers us a hero with such principles. Even so, we are left with a new version of the proclamation, "the state is I." Dworkin may find notions of the objective spirit both foreign and "scary," but surely this version of community personified is much "scarier."

Although Dworkin initially distinguishes between interpretation of the actual purposes embodied in social practices and the debates among the participants who perpetuate the purposes, ${ }^{123}$ he does not carry this distinction through to his description of Hercules' practice. This failure is not a coincidence. It results because Dworkin collapses two levels of community. On the one hand, he relies upon the interpretive context

119 See id. at 204-05.

120 See Williams, The Equality Crisis: Reflections on Culture, Courts and Feminism, 7 Women's Rts. L. Rep. (Rutgers Univ.) 175, 187 (1982) (discussing assumptions in the relationships between the sexes).

121 See R. Dworkin, supra note 20, at 65.

122 See id. at 239.

123 See id. at 239-40. 
provided by our language game or our form of life to provide us with a world that makes sense. The pregiven linguistic "community" allows us to appeal to, if not necessarily to agree upon, embodied principles and ideals. But this community is impersonal, a quasi-fact which precedes subjectivity and serves as a backdrop to our actual communal life. Because Dworkin does not develop explicitly the distinction between the "impersonal community" of linguistic context and the actual community of judges who interpret the law, he often moves between the two without noting the difference.

Dworkin's difficulty ultimately stems from his inadequate explanation of the basis of the social reality of embodied ethical ideals. The judge that Dworkin describes interprets the practice of other judges, rather than the collective ethics embodied in the law. As Dworkin explains, "[j]udges should decide what the law is by interpreting the practice of other judges deciding what the law is."124 In the end, integrity is in the judge and not in the embodied practices of a shared ethical reality. As Frank Michelman has correctly noted:

[T] he judge represents integrity-self-government-to the community, not of it. Second . . . - the self-government-of the judge is constituted by the conjunction in the judicial act, as experienced, of cognitive and volitional elements in tension. If and only if the subjective right-answer thesis is true, judges represent practical reason to the community. ${ }^{125}$

There is another, more subtle, problem with Dworkin's attempt to turn the community into a unified subject given voice in the judge. For Dworkin, the possibility of rational coherence is connected with the ability to turn the complexities of any actual community into a single mind. ${ }^{128}$ According to Dworkin, if we are to avoid checkerboard solutions, the community must think as if it were of one mind. Dworkin, in other words, wants to give us a legal system so highly rationalized that it attempts to do away with the inconsistencies that inevitably inhere in the particularization of right and to principle in any social order. The result is a very strained coherence, which, as we have already noted, carries within it the danger of perpetuating pretense in the name of rational order. Dworkin merges two different levels of analysis in his tale of the hero Hercules, even as he constantly attempts to distinguish

124 Id. at 410.

73 (1986).

${ }^{125}$ Michelman, Foreword: Traces of Self-Government, 100 HaRv. L. REv. 4, 72-

${ }^{128}$ See R. Dworkin, supra note 20, at 181-82. 
between academic philosophy and the practice of the judge. ${ }^{127} \mathrm{He}$ unites the elaboration of a rationally coherent system of law with the interpretive practice of an actual judge who can never completely escape the contingency of any existing legal system.

This mistake in turn relates to Dworkin's "rose-colored glasses" as the key to his interpretive method. ${ }^{128}$ An existing system of positive law, which can never escape the imperfection implicit in singularity and contingency, always carries within it basic flaws, at least if viewed from the standpoint of rational coherence. The tension between the aspiration to the ideal and the reality of contingency opens up the space for criticism and for reform. It is precisely because a complex community can never speak in a single voice that the aspiration to rational coherence is never fully met.

There is then a serious political, as well as an ethical, danger of merging the two levels of analysis. This is not to say that the principled judge should not constantly strive to overcome the inevitable tension between contingency and principle, but only to remind us that there is always more that can be done in the name of "rational coherence."

Moreover, while it is clear that the ideal of "rational coherence" stands in for the ideal in Dworkin, ${ }^{\mathbf{1 2 9}}$ he never really tells us what rational coherence is. What we do know is that it is not coherence in and of itself that is the good, for there could certainly be at least two interpretations, each equally coherent in its own stated assumptions. ${ }^{130}$ The ideal is rational coherence, which implies the enunciation of standards of reason. In order to make sense of the normative dimension of Dworkin's appeal to rational coherence, we need him to spell out a normative conception of reason. He must show us that what he offers in his tale of Hercules is not just the rationalization of what has been actualized, worse yet by one man, no matter how heroic he might be and in spite of his grandiose illusion that he embodies the community. When Dworkin puts on his rose-colored glasses, he projects coherence into the past as if it had actually been achieved.

If Dworkin's project fails, it does not fail for the reasons that a

127 See id. at 400 .

128 See id. at 54.

128 See id. at 46-47.

130 More importantly, as Hegel demonstrated long ago, "coherence" as the replacement for the conception of truth as representation demands the closure of the hermeneutical circle in Absolute Knowledge. See supra note 27 and accompanying text. Without closure, we are always positing an outside ideal or principle to which we attempt to make legal decisions cohere and which cannot itself be justified by the appeal to coherence. Furthermore, without the closure of the hermeneutical circle we cannot endorse coherence as a reality that definitively solves the problem of indeterminacy and serves as the solution to the dilemma of ethical meaning. 
conventionalist like Stanley Fish gives. ${ }^{131}$ Fish believes that in order to appeal to an ideal we must necessarily seek to uncover a behind or beyond to our current institutionalized social reality. ${ }^{132}$ But he is wrong to think that the very notion of an ideal rests on an appeal to a transcendental viewpoint. Norms, values, and ideals are also part of our social world. ${ }^{13 s}$

The problem with Dworkin's integrity is not that it is a principle or ideal and that principles and ideals are now outdated forms of foundationalism. We can accept Dworkin's point that there are embodied practices that express the community's principles and ideals, even if they can never be made fully present and therefore rendered immune from reinterpretation. Dworkin's project does not run into difficulty simply because he is concerned with the principled dimensions of law and of community, but rather because his break with positivism remains incomplete because he lacks an adequate philosophical framework in which to elaborate the objective spirit of law as an aspect of our collective ethics. In order to develop an adequate account of the ethical dimension of community and of law we need to begin again, starting with narration of the inherent sociality of subjectivity, which explains both the reality of belonging together in a properly constituted community and the role in it of legal and communal obligation.

\section{The Hegelian Conception of a Properly Gonstituted CoMmunity}

In this Part of this Essay, I will suggest that Hegel offers us a philosophical framework that, unlike Dworkin's own concept of law and community, does provide us with the three factors crucial to an adequate understanding of legal interpretation. First, he develops a non-contractualist understanding community based on a communitarian view of individuals, which at the same time appreciates the need to protect the sphere of private right. Second, he reveals the ethical "reality" of Sittlichkeit, which allows us to account for how "properties" such as integrity we normally associate with individuals, can be attributed to a community. Third, he gives us the realized relations of reciprocal symmetry as the embodied ideal expressed in the very conception of a modern legal system. It is this ideal that both justifies the rule of

131 See supra notes $16-17$ and accompanying text.

192 See supra notes 18-19 and accompanying text.

133 Fish's central mistake is to turn linguistic context into a self-enclosed, identical form. Without this move, Fish cannot justify his own rigid divide between the immanent and the transcendent, the real and the ideal. 
law and of individual expectation and at the same time provides a mechanism for assessing when it is valid to break with institutionalized meaning. In Hegel, we are obligated to the modern state only because it guarantees our legal personhood.

In order to understand Hegel's associative view of community we want to begin with the account of the development of self-consciousness in the Phenomenology. ${ }^{134}$ The starting place for such an account is Hegel's master/slave dialectic. Although any attempt to summarize the master/slave dialectic will fail to be true to the richness of Hegel's narration, we will be unable to grasp fully Hegel's understanding of communal obligation in the Philosophy of Right ${ }^{\mathbf{1 3 5}}$ unless we first come to terms with what Hegel means by the reciprocal constitution of subjectivity.

Hegel held that consciousness arises in and through the experience of a world that is other to the self. ${ }^{136}$ A sense of oneness with the world is shattered by the thwarting of desire in the confrontation with otherness. ${ }^{137}$ The striving to recreate the sense of oneness with the outside environment leads the self to negate the "otherness" of the other. The world of externality lurks as a persistent threat. The consciousness that arises out of the experience of negation seeks the coincidence of the "I" with itself through the subjugation of that which threatens its self-identity. As it is with the world of objects, so it is with the initial encounters with other selves. They too belie the coincidence of the identity of the "I" with all that surrounds it. They too must go under, if the "I" is to overcome its alienation from externality and make the world a home again. ${ }^{138}$

Other human selves are not so easily negated, however. They resist. In the contest of resistance, the " $\mathrm{I}$ " encounters itself in the other. The other that resists is like itself. What is encountered is the desire of the other for sovereignty played out in her resistance to being mastered. Yet, in the initial contest, the experience of the desire of the other does not lead to mutual recognition, but to a battle to the death, the ultimate negation of the self. ${ }^{139}$ The one who rises above the impulse to selfpreservation through the risk of death defeats the other who cowers before him. As he faces down his own fear of annihilation, he achieves

194 G.W.F. Hegel, Phenomenology of Spirit (A. Miller trans. 1977) [hereinafter Phenomenology].

${ }_{135}$ Philosophy of Right, supra note 23.

138 See Phenomenology, supra note 134, IIt 90-110.

137 See id. II 178-98.

138 See id. กा1 166-77.

138 See id. If 187. 
a new sense of identity. ${ }^{140} \mathrm{On}$ the other hand, the slave is the one who clings to the continuance of physical existence and ultimately submits rather than face death. ${ }^{141}$

Ironically, success in the effort to negate the other undermines the goal for which it was undertaken-the goal of finding oneself in the other through the assertion of one's subjectivity. The master no longer sees herself in the desire of the other. The other becomes a foreigner, an object, no longer able to pit her own desire against her opponent. The striving for the self-coincidence of the "I" with otherness turns against the aspiration to find oneself a home in the world. The achievement of mastery is self-defeating. We can only find ourselves in the other if she remains a subject, another desiring "I."

What is desired according to Hegel is not the other's submission, but the other's desire. ${ }^{143}$ Only another creature who also desires the desire of the other can recognize the "I" for the kind of unique selfconscious being she really is. In the moment of mutual recognition, the "I" experiences confirmation of her own self-consciousness as she in turn conceives the other as being like herself in that the other, too, is a self-conscious being. The stance toward the other is one of reciprocal symmetry. Each is recognized as a self, an " $\mathrm{I}$ ", by recognizing the other.

In Hegel, mutual self-recognition is the first glimmer of the Absolute, "the I that is we and the we that is I."144 The "I" of self-consciousness does not predate the social encounter. Instead, self-consciousness is understood to arise out of the clash of desiring wills in the struggle for mutual recognition. ${ }^{\mathbf{1 4 5}}$ It is important to note here that not only is self-consciousness a social achievement, it is an achievement fully realized only in a relationship of reciprocal symmetry and mutual co-determination.

Hegel then distinguishes between the consciousness, which arises out of the "negativity" of the experience of the outside world, and the self-consciousness which demands recognition by an interlocutor who is also a self-conscious being.

The concrete return of me into me in the externality is that I, the infinite self-relation, am as a person the repulsion of me from myself, and have the existence of my personality in 
the being of other persons, in my relation to them and, my recognition of them, which is thus mutual. ${ }^{148}$

The individual who is recognized as another " $\mathrm{I}$ " is recognized as a person. The autonomy of the other must be maintained if the other is to fulfill its destiny as a true Gegenspeiler, or equal interlocutor. It is, of course, important to note that the conclusion of the Lordship and Bondage is only the beginning of the realization of relations of reciprocal symmetry. The struggle between the self and the other opens up the highway of despair we must traverse before we reach Absolute Knowledge. For Hegel, it is ultimately only within a community of reciprocal recognition that personality comes to fruition and achieves normative validity as the very basis of the modern conception of right. The collective education ("Bildung") ${ }^{\mathbf{1 4 7}}$ that Hegel traces in the Phenomenology culminates in the self-awareness of the relation of personality to its constitutive other, the "we" of reciprocal recognition.

The "value" of personality, then, is not derived from transcendental arguments about human nature and rationality; instead, the right of individuals to be recognized as persons grows out of the establishment of an intersubjective practice. Recognition, Annerkennung, ${ }^{148}$ is not only the defining conception of self-identity in Hegel; recognition is also a normative practice embodied in the institutions of right themselves. ${ }^{149}$ Hegel's political philosophy does not begin with the hypothetical state of choice postulated in contractualist theories of obligation, but with the concrete, historical conditions of a human community in which the recognition of the individual entitlement to be a person is embodied in the law. We can now see how Hegel's assumption-that the achievement of a community of reciprocal recognition is necessary for the realization of subjectivity-affects his analysis of private right and of contract, and allows him to develop a noncontractualist, associative view of community that incorporates the modern notion of the legal person. Hegel justifies both property and contract as abstract forms of interaction com-

${ }^{148}$ G.W.F. Hegel, Philosophy of Mind If 490 (A.V. Neider trans. 1894) [hereinafter Philosophy of Mind].

${ }_{147}$ See W. Kaufmann, Hegel: Texts and Commentary 21 (1966) (noting that "education" is the best, but not an entirely adequate, translation for Bildung, and that the German literary genre Bildungsroman, novels relating to the education of the hero, best captures its sense).

${ }_{148}$ See Rauch, From Jena to Heidelberg: Two Views of Recognition, in Hegel's Philosophy of SPIRIT, supra note 25, at 47 (spinning out the sense, "love," and "struggle," in which Hegel used the term Annerkennung); Asseta, Commentary on "From Jena to Heidelberg: Two Views of Recognition", in Hegen's Philosophy OF SPIRIT, supra note 25, at 59 (arguing that in Hegel "the struggle for recognition" is the term's dominant sense).

${ }_{140}$ Philosophy of Right, supra note 23, II 4. 


\section{patible with the realized norm of mutual codetermination and reciprocal symmetry. ${ }^{150}$}

150 See id. II 217.

For Hegel, the right of private property is dependent upon the socially established right of personality. See id. If $40-41$. The "right" to own property is not and cannot be reduced to an immediate relationship between the appropriating subject and an external object. The simple, immediate relationship of appropriation is possession, not property. See id. If 49. Property is a social relation, dependent on an already existing legal system. See id. I 45 . The right of property is justified as the embodiment-if only on an abstract plane-of relations of reciprocal recognition: I recognize you and you recognize me as a subject capable of putting the will into an external object, thus making it one's own. The thing that embodies my will through the act of ownership is no longer just a mere physical thing. It is a medium through which my personality is given presence and is recognized by others. As Hegel explains, "[ $t]$ he thing ("Sache") is the means by which the extremes meet in one. These extremes are the persons." PhilosoPHY OF Mind, supra note 146, I 491. We respect the other's "right" to his property because we acknowledge him as a self-conscious being capable of embodying his will in an object. Property, however, is a social relation, not only in the sense that it takes place within a pre-given social context of binding ethical relations and is a legally regulated mode of behavior, but because the object of property is itself spiritualized through the mediation of the established means of ownership. Property, then, is doubly mediated, as a structure of reciprocally binding relationships between persons and as a social relation between the possessed object and the owning subject. Hegel replaces the myth of the isolated individual in a state of nature with a social conception of how the act of "possession" is legitimated as property through the mutually recognized rights of persons to preempt externality for their own purposes. There is, then, no "bright line" in Hegel between the subject and object, as Margaret Radin has argued. See Radin, Market-Inalienability, 100 HARv. L. Rev. 1849, 1891-98 (1987). The very opposite is the case. Property is ultimately a relationship between persons. The true object of property, in other words, is an intersubjective relationship. If there is a central message of Hegel's system, whether in the Phenomenology or in the Logic, it is that there can be no "bright line" between subject and object.

Radin's misreading stems from her failure to grasp correctly the significance of the structure of the Philosophy of Right. The Philosophy of Right begins with the "immediacy" of a description of the positive law as it has been codified. See PHILOSOPHY of RIGHT, supra note 23, โT 37-74. The description of abstract right with which Hegel begins is not a justification of it in the sense of a traditional argument. Hegel, in other words, is not defending the traditional, historical account of the sphere of abstract right as it was recorded in the jurisprudence of his day. In the jurisprudence of his time there was, indeed, the distinction between subject and object that Radin emphasizes. Hegel is not endorsing this divide. Indeed, it is only once we understand the relationship of abstract right to the whole of the modern state that we can uncover its truth. The Philosophy of Right is not a justification of the traditional conception of property and its relationship to personhood. Instead, the Philosophy of Right sets out to justify-although this is not how Hegel would have explained it-the curtailment of the sphere of abstract right and its correspondingly limited conception of the person through an appeal to the greater institutional context of the community, which reveals the "truth" of the legal recognition of property as the actualized relations of reciprocal symmetry. Although Hegel did not advocate the abolition of private property, he was a severe critic of civil society and the sphere of abstract right that grows out of it. See, e.g., Westphal, Hegel's Radical Idealism: Family and State as Ethical Communities, in The STATE AND Givil Society 77 (Z. Pelczynski ed. 1984) (explicating Hegel's notion of the state as constituting its citizens in the same way that a family creates the personality of its member, and as an ideal greatly at odds with the civil society of his day). 
The conception of oneself as a legal person gives way to the higher form of recognition of oneself as a member of the state. ${ }^{151} \mathrm{Hegel}$, in this sense, is a strong communitarian. The recognition that one is truly a citizen, and not mainly a member of civil society, has ethical as well as political significance. ${ }^{152}$ The state can legitimately demand the loyalty of its citizens only if it, in turn, has protected the conditions for the flourishing of individuality in and through the legally established relations of reciprocal symmetry. ${ }^{153}$ The truth of the whole, then, does not obliterate the immediate stage of abstract right with which Hegel begins the Philosophy of Right, because this immediate stage opens up the initial space for individuality. That is all it provides, because "true" individuality cannot be found in the sphere of abstract right. Once we understand that the truth of the sphere of private right is to be found in the reality of relations of reciprocal symmetry, we can grasp that the realized ideal that justifies property and contract also justifies their curtailment.

Hegel argues that the contract is based on the reciprocal recognition of each individual as a person. ${ }^{154}$ The very idea of the right to contract depends on the recognition of a subject of entitlement who cannot bargain away her status as a rights-bearing subject on the basis of imposed status obligations. For Hegel, the fundamental premise of the feudalism defeated by the bourgeois democratic revolutions is precisely the idea that the rights-bearing subject cannot alienate her own entitlement to personhood. As Seyla Benhabib has explained:

If contract is understood in its specifically modern sense as "the exchange of equivalents" in the market place, then it cannot be used as a norm to define the grounds of political authority in the modern state. These relations of obligation and authority derive their legitimacy from the fact that public rights of individuals are not private property, and cannot be alienated to others at will, but are secured by the impersonal and general norms of the rule of law. ${ }^{165}$

The right of contract, in other words, must be limited to the private sphere in which alienable goods are exchanged. What is and is not

181 See Philosophy of Right, supra note 23, II 251-60.

${ }^{152}$ The citizen must not only be willing to relinquish at least some of his property to the greater demands of the state, such as the need for redistribution through taxation, see id. TI 239-42, he must also be willing to give up his life in war, see id. If 326 .

16s See id. गी 142-57.

104 See id. IIा 71-75.

$18 s$ Benhabib, Obligation, Contract, and Exchange: On the Significance of Hegel's Abstract Right, in THE STATE aND Civil SocieTy, supra note 150, at 164. 
an alienable good is established only as an inter-subjective practice. According to Hegel's historical account, the legal person herself is no longer an alienable good, ${ }^{\mathbf{1 5 B}}$ because the very existence of the market is dependent upon the protection of the "free" person. ${ }^{157}$

Personhood is guaranteed by the public norms of the state; it is not something that exists by itself. The whirlwind of negotiations in civil society are now defined to exclude the loss of one's public status as a subject of right. We cannot bargain away our legal personhood, even if we can sell our laboring capacity. ${ }^{188}$ The self is supposedly not sold when the worker alienates her labor power; only a capacity of the self is sold. ${ }^{159}$ The relationship to the employer is "de-personalized."160 Personal relationships, such as those within the family, are removed from the sphere of abstract right. ${ }^{161}$ Slavery is illegal precisely because it demands the selling of the whole person, so that the person cannot opt out of the bargain. In other words, slavery would deny one's status as a subject of right who relates to the employer only on the "de-personalized" basis of contractual negotiations. Status distinctions no longer define who one is through a structure of nonbreachable obligations. This protection of the subject of right, while necessary for the existence of civil society, also only finds its truth in the whole. ${ }^{162}$ Civil society is subject to the communal relations of reciprocal symmetry in which the fundamental right to be recognized as a person itself cannot be subjected to contract. ${ }^{163}$

156 See PhIlosophy of Right, supra note 23, If 57, 65-67.

157 See id. at Additions I 38.

158 See id. II 66-67.

169 See id. If 67.

160 See id. II 66-67.

161 See id. 1775.

162 See id. If 182. The "values" of the market, such as efficiency, are also subordinated to the relations of reciprocal symmetry, which are essential for the continuation of civil society itself. If we all were allowed to sell ourselves into slavery, there would no longer be a market. In Hegel, the modern state is a complex unity of differentiated, if interrelated, social spheres. The state protects the sphere of the market, but not as a good in and of itself. The condition necessary for the sphere of the market to continue to exist, the recognition of each one of us as a subject of right, also provides a limiting principle by which the market is curtailed. The curtailment of the market is also justified in the name of the institutional differentiation that is the hallmark of the modern state. The community is the whole and not the sphere of civil society.

163 Reciprocal symmetry cannot be reduced to the traditional, contractual notion of reciprocity as an exchange in which there is a promise that if "good $A$ " is received, "payment" in some kind will follow. This view of reciprocity would be short-term, only applicable to the exchange once the promise between the parties had been made. This notion of reciprocity of exchangeable goods in a transaction is dependent upon the more fundamental reciprocity of mutual recognition. I respect my promise to you and the need for reciprocity in a transaction because I recognize you as a person like myself. Hegelian reciprocity implies our stance toward one another as legal persons over time. 
In this sense, the obligation to the state or community is fundamentally noncontractual. The individual is obligated to the state because it is the state or community that guarantees the limit to the sphere of private contract and that protects the very rights-bearing capacity essential to the maintenance of subjects capable of entering into reciprocally binding contractual relations within the; private sphere. The shift to a uniform system of centralized legal protection is necessary to break the hold of the pre-political feudal associations, in which the rights and the duties of individuality could be regarded as contractually regulated private property. Without this shift, there would be no objective protection of personality. For Hegel, the very ideal of modern personality begins-and only begins-with the legal recognition of each one of us as a person who cannot be completely identified simply by her social role. Hegel explains as follows: "Personality essentially involves the capacity for rights and constitutes the concept and the basis (itself abstract) of the system of abstract and therefore formal right."164

Of course, what I offer here is an interpretation of Hegel. But those who argue that the Philosophy of Right justifies the perpetuation of order ${ }^{165}$ miss the tension that Hegel maintains between the demands of actualized relations of reciprocal symmetry and the existent, positivity of any system of law or state. The myth of contractual obligation as the basis for the modern state is replaced by a narration that renders explicit the relations of reciprocal symmetry and mutual codetermination that have been realized in the democratic structures of the modern state. At first glance, Hegel's understanding of the relations of reciprocity may seem little more than a restatement of the ideal of formal equality. One major difference between the Hegelian ideal of reciprocity and the traditional understanding of formal equality is the following: Formal equality is best explained on a vertical plane as a relationship between the individual and the state. ${ }^{186}$ Each one of us as an individual is to be formally recognized by the state as an equal person. In Hegel, too, the very basis of the sphere of right is that each one of us is to be recognized as a formally equal person. In Hegel, however, the implicit emphasis is on the horizontal, internal relations and interactions between citizens, our stance vis-à-vis one another as distinct from

The democratic state embodies the ethical relation of mutual recognition, in which individuals recognize one another as equals, not only before the law, but also in their own relationships to one another as "persons" who can no longer be identified with established status hierarchies. The positive law expresses an achieved communal reality.

164 PhILOSOPHY OF Right, supra note 23, II 36.

165 See K. Marx, Gritique of Hegel's "Philosophy of Right" (A. Jolim \& J. O'Malley trans. 1970).

166 See id. 
our individual relation to the state. But Hegel also addresses the radical egalitarian aspirations implicit in the full development of the horizontal dimension of relation of reciprocity. These relations, in turn, guide us in our evaluation of any existing legal order. For Hegel, a system of law must meet certain conditions if it is to be consistent with the recognition of subjectivity. ${ }^{\mathbf{1 6 7}}$ Legal obligation is only warranted if the law upholds the formal right of individuals to be beholden only to those norms whose cognitive significance they can grasp. ${ }^{168}$ Law must be objective and public; "in view of the right of self-consciousness [it] must be made universally known."168 The form of modern law demands that the judge give reasons for her decision, which are an expression of the universal rather than of the particular interest of the opining judge.

By taking the form of law, right steps into a determinate mode of being. It is then something on its own account, and in contrast with particular willing and opining of the right, it is self-subsistent and has to vindicate itself as something universal. This is achieved by recognizing it and making it actual in a particular case without the subjective feeling of private interest; and this is the business of a public authority-the court of justice. ${ }^{170}$

For Hegel, a crucial characteristic of a modern legal system is that the sovereign no longer has the power to declare what the law is without giving demonstrable reasons and without allowing the subjected parties a chance to respond, ${ }^{171}$ that power is overturned once and for all. In this way, Hegel explicitly interjects the role of reason into a modern legal system. ${ }^{172}$ If a legal system is to respect personhood, it must do so by making laws accessible; that is, both publicly available and rationally understandable. ${ }^{\mathbf{1 7 3}}$ The individual must, in other words, be able to know what to expect, so she can live in accordance with those expectations. The ideal of the rule of the law, itself, then stems from the legal recognition of personhood.

Irrationality is identified with the former ability of the sovereign to change the law at will, so that the individual could neither know what was expected of her nor what her rights were against the state. She was subjugated to the will of the sovereign, not to her own will.

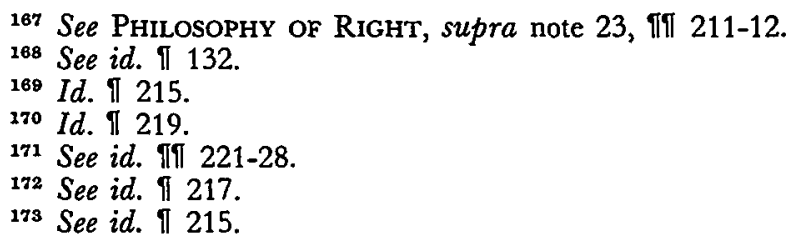


The end of the subjugation of the individual to the sovereign opens the door for individual freedom and agency. The legal system in a civil society must recognize the legitimacy of individual agency by giving the accused subject some rights to a defense and a response to the charges against him. The procedures established in the law courts protect this right to a response as essential to individual agency:

In court the specific character which rightness acquires is that it must be demonstrable. When parties go to law, they are put in the position of having to make good their evidence and their claims and to make the judge acquainted with the facts. These steps in a legal process are themselves rights, and their course must therefore be fixed by law. They also constitute an essential part of jurisprudence. ${ }^{174}$

The extension to all alike of the obligation to obey the law is the basis, for Hegel, of a legal community of public officials, itself a necessary condition for the authority of the act of judging. ${ }^{175}$ The judge, in her public role as judge, must act as an "organ of the law,"176 not as her own person. When she decides what the law is, she speaks with the voice of an authoritative community. Her statement must be subsumed "under some principle; that is to say, it must be stripped of its apparent, empirical, character and exalted into a recognized fact of a general type."177 Her opinion, in other words, must take the form of a legal judgment. As Gadamer explains the Hegelian position:

It is the work of interpretation to make the law concrete in each specific case; i.e. it is a work of application. The creative supplementing of the law that is involved is a task that is reserved to a judge, but [she] . . . is subject to the law in the same way as every other member of the community. It is part of the idea of legal order that the judge's judgment does not proceed from an arbitrary decision, but from this just weighing up by the whole. ${ }^{178}$

The judge herself is not the community personified. Rather, the principles she elaborates that express the norms of the community embody the objective spirit which cannot be reduced to a projected quasi-subjectivity. It is not that the judge personifies the community, but rather that

174 Id. II 222.

175 See id. กा $219,221$.

178 Id. II 226.

177 Id.

$178 \mathrm{H}$. Gadamer, supra note 66, at 352. 
she gives over her personality or her subjective will to her role as a public official who expresses the shared sittlich commitments of the community. ${ }^{179}$ The difference from Dworkin is subtle, but extremely important.

It is now becoming possible to see how Hegel provides us with an understanding of community life that denies that legal and communal obligation can only be legitimately enforced if the obligation is freely taken on as an act of choice. For Hegel, we have seen that the very idea of modern contractual relations rests on the public, legal protection of the noncontractual, inalienable status of each citizen as a rights-bearing subject. ${ }^{180}$ The obligation to belong to the community flows from the embodiment of the relations of reciprocal symmetry and mutual codetermination necessary for the full realization of personality in the concrete institutions of the state.

For Hegel, communal obligation does not conflict with justice. Instead, obligation is dependent upon the realization of the idea of freedom in the concrete, institutional structures of justice, which both enforce and limit the sphere of civil society. Justice is freedom actualized. Justice for Hegel is not, as it is for Dworkin, an abstract external theory or the subjective opinion of the individual. Instead, relations of justice are themselves a social practice, embodied in the conception and in the institutional structure of a modern, bourgeois democracy. Only a state whose institutions strive to actualize the relations of reciprocal symmetry can synchronize individual freedom with communal obligation. Hegel recognizes the validity of the impulse behind contractualist theories of justice. $\mathrm{He}$ understands how the insistence on the realization of certain hypothetical conditions of choice, if obligation to the state is to hold, protects the modern notion of individuality. Reciprocity within a legal system means that without the recognition of right, there is no duty. "Hence in this identity of the universal will with the particular will, right and duty coalesce, and by being in the ethical order a man has rights in so far as he has duties, and duties in so far as he has rights."181

Freedom is no longer merely a projected ideal but rather a substantial reality in which reason has been determinatively actualized in the institutional relations that embody the "norm" of reciprocal symmetry. These relations allow the modern individual to come into the stage of history. As an "objective" set of institutions, the ethical order of the

179 See infra note 244 and accompanying text.

180 See supra notes $155-63$ and accompanying text.

181 Philosophy of Right, supra note 23, II 155. 
state or community stands over and against the individual.

The substantial order, in the self-consciousness which it has thus actually attained in individuals, knows itself and so is an object of knowledge. This ethical substance and its laws and powers are on the one hand an object over against the subject, and from his point of view they are-"are" in the highest sense of self-subsistent being. . . .

... [Ethical laws] are not something alien to the subject. On the contrary, his spirit bears witness to them as to its own essence ....182

With the achievement of Absolute Knowledge, the self-conscious recognition of the " $T$ ' that is ' $W e$ ' and the 'We' that is ' $I$ ',"'183 the individual subject grasps how the state or community is the basis for the full realization of her own subjectivity. The individual comes to affirm the community "as in his own element which is not distinguished from himself."184 This necessary moment of subjective affirmation separates the modern synchronization of the individual with the community from the simple identity of the citizen with her state, which Hegel associated with ancient Greek culture. ${ }^{185}$

The synchronization of the individual with her community is always a self-conscious reconciliation. The self-consciousness that arises out of mutual recognition is both a social achievement and, at the same time, the actual realization of individuality. The subjective moment of affirmation is essential to Hegel's understanding of how ethical order is perpetuated. ${ }^{186}$ The ethical order is not simply there as the dull weight of positivity; rather it is there for us. Nor, however, can it be reduced to the accepted conventions of individuals. There are, as Dworkin reminds us, "real" social practices, which we interpret. ${ }^{187}$ The unity of subjective affirmation with the objective institutions of right embody "mind living and present as a world, and the substance of mind thus exists now for the first time as mind."188

\footnotetext{
182 Id. TI $146-147$.

183 Phenomenology, supra note 134, I 177.

184 PhILOSOPHY OF RIGHT, supra note 23, II 147.

188 See id. II $150,257$.

${ }^{186}$ See id. Tा 142-43.

187 See R. Dworkin, A Matter of Principle 214-20 (1985).

${ }_{188}$ Philosophy of Right, supra note 23, II 151.
}

Our objective, institutionalized legal context, in other words, recognizes the "I" as a social reality. The state protects the sphere of private conscience reinforced by the legal recognition of the person as a being who cannot be owned by the state or by another individual. The disjunction between the self and her social role is itself an "objective" reality in our social world. 
Within Hegel's own system, the distinction between actuality and positivity prevents the reduction of ethics to the perpetuation of order. On the interpretation of Hegel offered here, the institutions of freedom are not justified simply because they are there; instead they are legitimated because they are the very embodiment of the ideal of reciprocal symmetry. We are obligated to belong to the modern state only because it is a community of principle. From a Hegelian perspective, Dworkin's ideal of integrity in the law is not self-sustaining; it is itself an expression-on the plane of abstract right-of relations of mutual recognition. The conditions that Dworkin associates with law as integrity, rational accountability, and fairness in application inhere in the very idea of relations of reciprocity. If law is to be publicly known and cognitively accessible, then the commitment to the elaboration of principles inherent in the ethical order-what Dworkin calls consistency in principle-is necessary. But if we are to avoid reducing justice to an external theory or to personal opinion, as Dworkin does, we must first elaborate the actual relations and institutions in which those principles inhere. It is not enough simply to appeal to rational coherence or consistency-inprinciple; we must know what the principles are with which we are trying to be consistent. These "principles," however, are not external; they are related to the actualized relations of reciprocity.

Hegel's insistence on the reality of community can provide the philosophical basis for Dworkin's argument that "properties" such as integrity, normally associated with the subject or self, can be embodied in communities. For Hegel, ethical order, or Sittlichkeit, is real objective spirit. ${ }^{189}$ Nor can individuality be separated from the social and the

As an account of the actual, the Philosophy of Right narrates the truth of what has already been achieved. In Hegel, real potential (or the essence of the real) ultimately finds its complete fulfillment. Potential no longer serves as more than that which is inherent in social reality itself. Nevertheless, it would be a serious misreading of Hegel to conclude that his practical philosophy is a mere apology for what is. Hegel only begins with what is immediate, and he does so in order to show that its truth is not as immediate as it initially appeared. Hegel's entire system rests on the distinction between what is "actual" and what "exists." An entity whose essence has been actualized, whether it be a state or a person, "appears" as what it truly is. There are certainly entities that fail to "appear" as their true essence. We can judge these as inadequate expressions of their true essence. The philosophy of right is the philosophy of the truth of actuality, not of the truth of what is. Here again, we see the difference from Fish. For in Fish there can be no such tension between actuality and the merely existent.

${ }_{189}$ We can easily draw a connection between Hegel's notion of Sittlichkeit and the later Wittgenstein's emphasis on the communitarian or sittlich character of linguistic meaning. Wittgenstein believed that the world we live in-including our ethical reality-is socially constructed in language. See Philosophical Investigations, supra note 11, ITा 206-10 (stating that our world is characterized by social rules, which we express through language). We learn to refer, to make sense, through our participation in a pregiven linguistic community. To the degree we seek to communicate, we are 
communal structures that sponsor its flourishing. Mutual codetermination is not just an ideal; it is the reality of who we are as members of the state. We cannot completely sever the "being" of the individual from the "reality" of the community. If we are to "value" subjectivity and grapple seriously with the aspiration to individual freedom expressed in contractualist notions of the communal obligation, we must both counter atomic views of subjectivity and defend the reality of community life. To accomplish this task successfully we need an account of subjectivity both as a social reality itself and as a narration of the "objective spirit" of cultural institutions understood as an "actress" on the stage of history. This is precisely the dialectic that Dworkin does not adequately comprehend. To reduce "objective spirit" to the voice of a single author, as Dworkin does with Hercules, undermines completely the idea that the unity of the many selves is achieved only through their self-conscious identification with the community. Furthermore, it undermines the idea that such an accomplishment is always an intersubjective and mediated experience.

Hegel did not aspire to the full rationalization of any existing system of law. Legal interpretation involves a moment of singularity and contingency, which inevitably thwarts the aspiration to rational coherence. For Hegel, we must always distinguish between a philosophy of right and the actual practice of legal interpretation. As Adrian Peperzak has explained the Hegelian position:

As a reality in time and place, the order of factuality is characterized by singularity (Vereinzelung). The factual is only that which is real here and now, and which in that sense is unique-occurring at only one time, in one place. . . . Considering the fact that contingent factuality is the opposite of the pure concept, but at the same time its dark inner lining, as it were, by which the concept delimits itself, factuality is also characterized by irrationality, appearance and contradiction. Left to itself it would sink into chaotic confusion and self-destruction. Only in so far as it partakes of the rational principle of spirit, does factuality not perish but rather realize rationality. In so far as the positivity of right involves an element of singularity and contingency, it also involves that inner contradiction. That is why Hegel defends as necessary the inconsistencies of every legal system to lawyers who want 
to hide them behind a strained coherence. ${ }^{190}$

Here again we can see Hegel's difference from Dworkin and Fish. Unlike Dworkin, Hegel does not strive after the strained coherence that results from collapsing the level of the philosophy of right into the actual interpretive practice of a mythical judge. At the same time, and unlike Fish, Hegel recognizes the reality of ideals and principles that do indeed guide the judges and lawyers, because they are embodied, if imperfectly, in the social practices we think of as law. ${ }^{101}$

As suggested above, our shared ethical order, or Sittlichkeit, is "real" in Hegel's theory. ${ }^{192}$ In his insistence on the reality of our shared sittlich commitments, Hegel anticipated the Wittgensteinian challenge to the identification of ethical statements as "queer" entities. ${ }^{193}$ Our "reality of historical understanding," our form of life, embodies ethical commitments as well as "facts." The world of instituted meaning is our world. The assemblage of accepted uses and practices that constitutes a form of life and that precedes all intentionality and subjectivity gives us a sensible world and a world that makes sense. Within our form of life, including our legal context, there are standards of rationality to which we appeal in our day-to-day practice. For Hegel, those standards of rationality are embodied in actual institutions and can be made explicit in their objectivity. Legal interpretation takes place within the parameters of our ethical order, or Sittlichkeit. Law, for Hegel, is ethics. ${ }^{194}$ But law is not morality in the sense of the specific commitments of the individual conscience. It is the containment, if not the confinement, of legal judgment on a horizon of ethical understanding, which allows for the perpetuation of a potentially coherent narration of legal principles, irreducible to the mere opinion of the individual judge.

The appeal to Sittlichkeit in and of itself, however, only explains the possibility ${ }^{198}$ of an intelligible ethical and legal order. In order to spell out the normative basis of a properly constituted community with a legitimate legal system, we need to look at the institutional and ethi-

190 A. Peperzak, Philosophy and Politics 9 (1987) (footnotes omitted).

101 See Philosophy of Right, supra note 23, ๆ 216.

102 See supra note 24 and accompanying text.

${ }^{103}$ See TRACTATUS, supra note 12, I 6.42.

194 See Philosophy of Right, supra note 23, đ 146.

105 I use the word "possibility" deliberately. There is no magic in the appeal to Sittlichkeit that guarantees our shared ethical reality will not be effectively corroded. But precisely because we are inside our form of life and therefore cannot delimit the entire repertoire of community standards, we cannot know for sure that ethical reconstruction and immanent critique have been rendered impossible. Hope and the responsibility for which it calls always remain. 
cal content of Sittlichkeit, not simply affirm its existence. Such an affirmation would tell us only that ethical standards existed, but not necessarily that they were adequate to a modern conception of a democratic legal system. In Hegelian language, the actual would be collapsed into the existent. In the Philosophy of Right, Hegel gives us an institutional analysis of a properly constituted democratic state. A crucial aspect of this analysis is an account of the historical development of the sphere of abstract right, with its recognition of the legal person. As we have seen, this account locates the legitimacy of the sphere of abstract right in the realized relations of reciprocal symmetry. It is the realized relations of reciprocal symmetry that provide us with a rational limiting principle to guide legal interpretation. ${ }^{198}$

\section{The Crituque of Hegel}

Hegel provides us with a philosophical framework that allows us to develop the conception of a properly constituted community which is necessary if we are to have a framework for legal interpretation that can successfully break with positivism. Dworkin's own break with positivism, despite his intentions, is incomplete. Hegel's account of the intersubjective basis of self-consciousness, shows us both how the individ-

${ }^{198}$ The appeal to Sittlichkeit allows us to comprehend the framework of intelligibility in which ethical and legal judgment takes place. In Hegel, however, a philosophy of right can achieve validity because it is the retrospective account of the realized conception of a modern legal system whose essence is both rationally accessible and fully determinate. We cannot read Hegel's Philosophy of Right separately from the Logic.

The Logic culminates in Absolute Knowledge. See Logrc, supra note 27, at 82444. The phrase Absolute Knowledge may sound very strange to the American ear, but the achievement of such knowledge is the aspiration of the metaphysical tradition beginning with Plato. See id. at 831. By the achievement of Absolute Knowledge, I mean to indicate the achievement or the revelation of the truth of the essence of Being. For Hegel, the truth of the actual is the embodied concept or Geist. See id. at 529; 3 THE ENCYClopedia of Philosophy 275-76 (1972). Hegel, in this specific sense, is an absolute idealist, not because he denies the existence of reality, but rather because in his demonstration that the truth of reality can only be found in mind or spirit.

At first this notion might seem hopelessly outdated. We can connect it to the Wittgensteinian lesson that no reality for us is presented in our interpretive framework and through our accepted representational systems. See PhiLosophical InvestigaTIONS, supra note 11, at 61-75. This, of course, should not necessarily be taken to mean that all that is is only what is there for us. That is the central mistake of absolute idealism. See supra notes $96-111$ and accompanying text. But the subtlety of Hegel's own conception of the truth of the real as spirit demands that we examine it carefully in order to understand exactly how it leads us astray.

We can understand what is still modern and indeed post-modern in Hegel's understanding of the relationship between thought and being if we look at what he says about the category of Being in the opening moves of the Logic. See LoGIC, supra note 27 , at 82-184. In his Logic, Hegel tries to show the actuality of the reciprocal codetermination of meaning and being. See PhILOsophy of MIND, supra note 146, at 529-71. 
ual is from the beginning a part of her community and why the community itself has an objective status. The community constitutes the legal person as the individual intact; the state is not created through the will of individuals who create their own community through contract. Hegel, then, demonstrates the fallacy in contractualist theories of community. At the same time, Hegel, unlike Dworkin, effectively grapples with the root of the appeal of these theories. Hegel recognizes that such theories have continued to hold sway because of their appeal to individual right as the basis for legal obligation. He shows us that there are immanent embodied ideals within a modern legal system that provide principles of individual right that can meet the legitimate concerns of contractualist theorists. Hegel recognizes, as Dworkin does not, that we need to make justice the criteria for legal obligation if we are to respect the modern conception of individuality in any philosophy of right.

Hegel thus meets Dworkin's aspiration, as Dworkin himself cannot, to elaborate an associative view of community and legal obligation that grapples both with individual right and with the limits of contractualist justice. In order for a modern legal community to demand our obligation, it must embody-at least on the level of its conception-the actualized ideal of reciprocal symmetry. As legal persons, we promise fidelity to the ideal of reciprocal symmetry that protects our individuality. To the degree that the legal system fails to live up to the actualized relations of reciprocal symmetry, it can be said to demand our infidelity in its own name. This understanding of the relationship to the ideal allows us to grasp why infidelity may be necessary for integrity to be principled.

When we speak of the promise or the commitment to the ideal, we have already moved beyond Hegel. For Hegel, it is the truth of mutual codetermination in relations of reciprocity that provides the shining light against the threatened darkness of nihilism.

As a result, we must also understand that there is an inescapable conservative impulse in the Hegelian fusion of truth and history, and of meaning and being. Full achievement of the unity of meaning and being is a temporal achievement within history, but the historical struggle toward reconciliation is completed with the self-conscious coming home of Geist to itself. There are several dimensions to Hegel's ultimate conservatism. The first is that, because the truth of the actual has supposedly been realized, philosophy, as a speculative system, can only play a retrospective role in history. As Hegel himself puts it in the Philosophy of Right, "[t]he owl of Minerva spreads its wings only with the falling 
of the dusk." 107 There is no prospective role for the imagination to play in philosophical or ethical discourse. The later Hegel reminds us again and again of the danger of the so-called illusion that we can self-consciously will a new society into existence by imagining and then attempting to enact utopian schemata. ${ }^{198}$

The role left for the individual subject is only the self-conscious affirmation of the objectified truth or Reason embodied in the conception of a democratic state. The subject, in other words, does not play an imaginative or creative role in political or social reconstruction. At least as a player in the actual theater of real politics, the individual finds herself effectively tied to what has been actualized. In this way, Hegel denies the full significance of his recognition of the principle of subjectivity to modernity.

The conservative impulse in Hegel results from his ultimate move to achieve totality. The move to totality traps us in the circle of Absolute Knowledge ${ }^{\mathbf{1 9 8}}$ and creates another problem with Hegel's theory, namely that there is no room in Hegel's theory for "indeterminacy" and, at least under the standard reading of Hegel, no room for real potential. We achieve determinacy in Hegel only with closure, and it is precisely the idea of closure as the exclusion of otherness and potential that has been philosophically and ethically criticized, first by the American philosopher Charles Peirce. If we are to preserve, and yet also expand Hegel's institutional analysis of a properly constituted democratic community, we must approach his Philosophy of Right from an interpretive stance different from the one offered by Hegel, himself, in his philosophical system. The starting point for this necessary shift from Hegel's systematic philosophy is the pragmatic critique of Hegelianism developed in the work of Peirce.

The version of pragmatism developed in this Essay by interpreting

197 Philosophy of Right, supra note 23, at 13.

198 See id. at 10-13. Habermas has criticized Hegel for the error of tying ethical and political meaning to the rock of the past, summarizing the Hegelian position as follows:

Philosophy cannot instruct the world about what it ought to be; it is solely reality which is reflected in its concepts, reality as it is. It cannot direct itself critically against this, but only against the abstractions which push themselves between reason become objective and our subjective consciousness. Philosophy can level its critique against Frees and the Student Associations [Burschenschaften], but not against the institutions of the state. It does not present any guide line for revolutionizing praxis, but only a lesson to those who falsely employ philosophy as an inspiration for political action.

J. Habermas, Theory and Practice 178-79 (J. Viertel trans. 1968).

109 See supra notes $134-47$ and accompanying text. 
Charles Peirce is very different from the legal pragmatism that Dworkin rejects. Through the pragmatic critique as it appears in Peirce's work we will be able to see the significance of the pragmatic "as if" that Dworkin mistakenly identifies with instrumentality. We will also come to grips with the significance of the disruption of Hegelian totality for a postmodern understanding of Hegel's own philosophy of right. Once the Hegelian system is disrupted, we can no longer simply recollect the truth of legal principles as if they were just "there." The process of legal interpretation is a process that involves the imagination.

Peirce correctly insists on the primacy of the imagination in interpretation. ${ }^{200}$ But we will still need to develop Peirce's insight if we are to reach an adequate understanding of what I call recollective imagination. From my discussion of the recollective imagination and the reality of potential as the truth of indeterminacy, I will turn to the normative vision of community that survives the deconstruction of Hegel's system and to the role of reason in the development of the innovative capability that allows for change in both individuals and institutions. We need not deny the reality of the institutionalization of meaning or the legitimacy of the critique of the self-constitutive, meaning-giving subject in order to argue for transformative potential. Such potential inheres in the indeterminacy of any pre-given linguistic context.

\section{The Truth of Indeterminacy, the Reality of Potential, and the Process of Recollective Imagination}

\section{A. What Exactly is the Indeterminacy Thesis?}

Perhaps no phrase has been more misunderstood by legal scholars than the "indeterminacy thesis" developed by the Conference of Critical Legal Studies. ${ }^{201}$ The "indeterminacy thesis" as it has been interpreted by its critics-and sometimes, if rarely, by its proponents-is taken to mean that the critique of the logic of identity, which reflects the idea

200 See infra notes 217-25 and accompanying text.

201 See, e.g., Kairys, Law and Politics, 52 GEo. WASH. L. Rev. 243, 244, 247 (1984) ("The starting point of critical theory is that legal reasoning does not provide concrete real answers to particular legal or social problems. Legal reasoning is not a method or process that leads reasonable, competent, and fair-minded people to particular results in particular cases. . . . The ultimate basis for a decision is a social and political judgment incorporating a variety of factors, including the context of the case, the parties, and the substance of the issues. The decision is not based on, or determined by, legal reasoning."); see also Solum, On the Indeterminacy Crisis: Critiquing Critical Dogma, 54 U. GHI. L. REv. 462, 463-64 (offering a number of sources of definitions of indeterminacy). 
that there is a self-enclosed form of life to which we can appeal in order to cement meaning, leads us to conclude that there are no shared standards of communicability. ${ }^{202}$ But this is a mistaken interpretation of indeterminacy. It means instead that we do not question by gazing down on institutionalized standards of communicability from a transcendental viewpoint; we question from within our shared context. Yet, as we question, we also inevitably affirm meaning as the "basis" for our understanding of the process of questioning itself. Charles Peirce has explained that we can only begin questioning from within a given linguistic context with established interpretations of signs. ${ }^{203}$

Perhaps no one studied more carefully than Peirce the way meaning is institutionalized and then internalized as the habitual structures of thought we take for granted as our representational schema. Yet Peirce was one of the first thinkers to insist on the "indeterminacy" of any linguistic or semeiotic field. If indeterminacy is not the outright denial of shared standards of intelligibility, then what exactly is the truth of indeterminacy?

In order to answer that question, we must return to the critique of Hegel I have already initiated. We must also explore the truth of indeterminacy on several different levels. ${ }^{204}$ For Charles Peirce, to think

${ }^{202}$ This conclusion does not follow from Wittgenstein's Philosophical Investigations, nor even from Derrida's deconstructive exercises. Derrida, in particular, is only too well aware of the hold that institutionalized meaning has on us. He does not, in other words, deny the reality of Sittlichkeit, but only its self-enclosure. In his response to John Searle, often cited for the proposition that the "indeterminacy thesis" necessarily dissolves the appeal to shared meaning in the endless play of the signifier, Derrida carefully reminds us:

Is it certain that to the word communication corresponds a concept that is unique, univocal, rigorously controllable, and transmittable: in a word, communicable? Thus, in accordance with a strange figure of discourse, one must first of all ask oneself whether or not the word or signifier "communication" communicates a determinate content, an identifiable meaning, or a describable value. However, even to articulate and to propose this question I have had to anticipate the meaning of the word communication: I have been constrained to predetermine communication as a vehicle, a means of transport or transitional medium of a meaning, and moreover of a unified meaning.

Derrida, Signature Event Context, 1 Glyph 172, 172 (1977).

Derrida constantly refutes radical skepticism on this basis: as we question shared meaning in the name of the polysemantic aspects "present" in any definition given to a particular word, we also appeal to shared meaning in the very process of questioning. See id. at 186-93.

${ }_{203}$ See 5 C.S. PEIRCE, supra note 28, I 289; Yablon, The Indeterminacy of Law: Critical Legal Studies and the Problem of Legal Explanation, 6 CARDozo L. REv. 917 (1985) (reconciling the claim that law is indeterminate with the experience of lawyers that law is predictable).

${ }_{204}$ As I have already suggested, the ontological unity of meaning and being is revealed within the Hegelian circle of Absolute Knowledge. Actuality becomes fully 
that the truth of all reality lies in the realized whole, the self-conscious return of Geist to itself, is the central mistake of Hegel's absolute idealism. In the language of semeiotics, reality cannot be reduced to the objective norms of Sittlichkeit or fully captured by a system of signs. The "real" cannot be reduced to the ideal. There is always an excess that disrupts the full identity of the sign with its object. A sign is always in referential relation to some other sign or interpretant. Signs are never simply self-referential or mere representations of an object. In this sense, there can be no full determinacy of any institutionalized system of meaning, because the sign itself always points us to another sign beyond the repetition implicit in self-reference. As long as the sign is determined in a relation to its other, there can be no closure of the process of interpretation. The otherness of thought to being inheres in the insight that we think only within a semeiotic field in which reference always involves an appeal to another sign and not directly to the object that it represents. The disruption of totality is the result of the inevitable diachronic moment in any semeiotic system. The diachronic moment disrupts the full reconciliation of meaning and being, which allows Hegel to recollect the past. The beyond to the system is "there" in the diachrony, which prevents self-enclosure. On one level, then, the "indeterminacy thesis" is the recognition of the otherness to the concept that disrupts Hegelian totality and opens the chasm between meaning and being, or what Peirce called Secondness. ${ }^{205}$

\section{B. The Peircean Critique of Absolute Idealism}

The category of Secondness is the key to understanding Peirce's break with Hegel's absolute idealism. Secondness is the real that resists, or what Peirce himself has called the "Outward Glash." ${ }^{206}$ Secondness is that against which we struggle and which demands our attention to what is outside ourselves and our representational schema. By Secondness, Peirce means to indicate the "mutual action between two things regardless of any sort of third or medium, and in particular regardless of any law of action." 207 Secondness is dualistic precisely because it involves struggle. What I earlier referred to as the irreducible exteriority of suffering is an example of what Peirce would have called Secondness. ${ }^{208}$ The past that cannot be wiped out is Secondness to Peirce.

adequate to our present in its concept. In this sense Hegelian philosophy is the ultimate expression of what Jacques Derrida has called "the myth of full presence."

${ }^{205}$ See 1 C.S. PEIRCE, supra note 28, TT 322-36.

${ }^{208}$ See 8 C.S. PeIRCE, supra note 28, iा 41.

2071 C.S. PEIRCE, supra note 28 , I 18.

208 See supra notes $101-10$ and accompanying text. 
In order to justify his category of Secondness, Peirce does not need to deny the mediation of all human knowledge of reality. Secondness is what is left over, that which cannot be fully captured by any system of signs. Secondness reminds us that there is ground under our feet. We are in a world of fact "as well as" of fancy. For Peirce, as I have just indicated, there is also a direct link between the past and Secondness. "We may say that the bulk of what is actually done consists of Secondness-or better, Secondness is the predominant character of what has been done." ${ }^{209}$ For Peirce, all knowledge of reality, on the other hand, is triadic. Human knowledge is enfolded in the habits, rules, signs, and modes of conduct that Peirce designates as thirds. ${ }^{210}$

Thirdness is the category usually associated with Hegel's Sittlichkeit, but with the major difference that the time frame of Peirce's Thirdness turns us toward the future-if in a very specific sense-rather than toward the past of what has been actualized. As Peirce explains: " $\mathrm{N}] \mathrm{o}$ matter how far specification has gone, it can be carried further; and the general condition covers all that incompletable possibility."211

Peirce often used the example of law to demonstrate the significance for interpretation of his category of Thirdness. His example of "giving" demonstrates the triadic structure of Thirdness:

A gives $\mathrm{B}$ to $\mathrm{C}$. This does not consist in A's throwing $\mathrm{B}$ away and its accidentally hitting $\mathrm{G}$. . . . If that were all, it would not be a genuinely triadic relation, but merely one dyadic relation followed by another. There need be no motion of the thing given. Giving is a transfer of the right of property. Now right is a matter of law, and law is a matter of thought and meaning. ${ }^{212}$

2001 C.S. PEIRCE, supra note 28, II 343.

210 See id. I 209.

211 Id. If 475. For Peirce, the opening to the future results from his understanding of a sign or a proposition.

The rational meaning of every proposition lies in the future. How so? The meaning of a proposition is itself a proposition. Indeed, it is no other than the very proposition of which it is the meaning: it is a translation of it. But of the myriads of forms into which a proposition may be translated, what is that one which is to be called its very meaning? It is, according to the pragmaticist, that form in which the proposition becomes applicable to human conduct, not in these or those special circumstances, nor when one entertains this or that special design, but that form which is most directly applicable to self-control under every situation, and to every purpose. This is why he locates the meaning in future time; for future conduct is the only conduct that is subject to self-control.

5 C.S. PeIRCE, supra note 28, II 427.

2121 C.S. PEIRCE, supra note 28, II 345. 
The condition of generality, or "law likeness," pervades all thirds. The openness to the future inherent in Thirdness yields an essential indeterminacy that cannot be theoretically, or even practically, overcome once and for all.

For Peirce, human conduct, precisely because it is general and habitual and embodied in thirds, includes "would be's"213 and thus a future potential that cannot be reduced to repetition of the past. ${ }^{214}$ The very habitual structure of sittlich commitments leaves the habitual "structures" open-ended. To argue, then, that we are immersed in an already given historical reality of understanding is not to turn that reality into a prison, which bars us from innovative capability, for the exact opposite is the case. To quote Richard Bernstein:

Conduct or habit consists of what Peirce calls "would be's." To say that a person or a thing has a habit means that it "would behave (or usually behave) in a certain way whenever a certain occasion should arise." Although conduct, habits, or "would be's" issue in action, "no agglomeration of actual happenings can ever completely fill up the meaning of a 'would be.' " We can now see more clearly why Peirce insists that all Thirds are future-oriented. While the past is the "storehouse of knowledge" and "whenever we set out to anything we 'go upon,' we base our conduct on facts already known;" the laws, habits, and conduct that we come to know are not exhausted by past regularities. If they were, they would be mere regularities not genuine laws to Thirds. The conditional generality of Thirdness is not exhausted by any finite set of past, present, or future happenings. ${ }^{215}$

It is still, of course, correct to argue that our habits are encased in the storehouse of knowledge, which includes the accepted generalities and regularities that make conduct sensible. ${ }^{216}$ Even if the conditional generalities of conduct cannot be reduced to any given set of past regularities, they are still dependent on them to the degree that they arise

2138 C.S. PEIRCE, supra note 28, If 380.

214 See 5 C.S. PeIRCE, supra note 28, II 461.

215 Bernstein, Action, Conduct, and Self-control, in Perspectives on Peirce, supra note 30, at 77-78 (omitting references).

${ }^{216}$ See supra notes 206-12 and accompanying text. We can now use Peirce's understanding of the essential indeterminacy of Thirdness to uncover the fundamental mistake inherent in Stanley Fish's "internal realism." For Peirce, as already suggested, Hegel's central mistake was to reject the real possibilities of things in the future. As we will see, Fish makes the same mistake. Fish's error, simply put, is to reduce the conditional generality of Thirdness to a finite set of past and present regularities that replicate themselves in and through institutional structures. 
out of them. As Peirce explains:

How, then, does the Past bear upon conduct? The answer is self-evident: whenever we set out to do anything, we "go upon," we base our conduct on facts already known, and for these we can only draw upon our memory. It is true that we may institute a new investigation for the purpose; but its discoveries will only become applicable to conduct after they have been made and reduced to a memorial maxim. In short, the Past is the storehouse of all our knowledge. ${ }^{217}$

Interpretation, then, is retrospective in the sense that we always begin the process of interpretation from within a pregiven context. The process is also prospective, because it involves elaboration of the "would be's" inherent in the context itself. Peirce explains that ascertaining the meaning of a norm or proposition involves us in an imaginative enterprise. We conjecture what it would mean if we were to conduct ourselves in accordance with a particular proposition or habit of mind.

We imagine ourselves in various situations and animated by various motives; and we proceed to trace out the alternative lines of conduct which the conjectures would leave open to us. We are, moreover, led, by the same inward activity to remark different ways in which our conjectures could be slightly modified. The logical interpretant must, therefore, be in a relatively future tense. ${ }^{218}$

The logical interpretant is the conjecture inherent in a general proposition. We ask ourselves what it would mean if we were to guide ourselves and live in the world in accordance with a particular conjecture. The "as if" as a process of understanding is part of our day-today law school culture. We practice the "as if" in the hypotheticals we use to teach students the meaning of a particular legal rule or proposition. We ask our students to grasp the meaning of the rule through conjecture. The "as if" is oriented toward the future in that we project the proposition onto future situations in order to draw out its meaning. This future is implicit in the act of interpretation. As Peirce argues, "the species of future tense of the logical interpretant is that of the conditional mood, the "would be." "219

We understand the meaning of a right through this same process of conjecture. The meaning of a right as a general proposition is uncov- 
ered in the process of conjecture just described. Dworkin is wrong to suggest that "[l]aw as integrity, is more relentlessly interpretive than . . pragmatism."220 The whole point of Peirce's semeiotics is to show that all knowledge is interpretive. The disagreement lies in Peirce's belief that the very process of interpretation demands conjecture and, therefore, the imagined "would-be."221 The insistence on the future as the horizon for the effectuation of meaning is not instrumentalist. It ' does not deny the text in favor of an instrumental vision of the future. Nor does it deny that we are always oriented toward the past precisely because we are in a pregiven context. The future orientation of which I speak has two divisions. First, there is no past that is simply "there" for us to recollect since all signs only refer to other signs and not directly to reality. As a result-and this is the second division-we seek the meaning of an account of our legal history, in how it guides us in our future conduct, since we cannot validate its truth as a purely descriptive manner. Since the "past" is always offered to us within competing interpretive frameworks, we cannot prefer one framework over the other because one is not a framework at all but a pure account of what "actually is." We must, instead, look to how these accounts can guide us in grappling with the legal problems we are now confronting. The very idea of the meaning of the text itself arises in and through the process of conjecture. Peirce explains as follows: "Pragmatism makes the ultimate intellectual purport of what you please to consist in conceived conditional resolutions . . . "222 There are, in other words, conceived conditional resolutions that do stabilize meaning. Indeed, a judge's decision can itself be understood as a conditional resolution, which, if it is enforced, will effectively stabilize legal meaning.

But what I have just argued should not be confused with the position that would simplistically deny the material weight of the past in favor of the view that resolution is purely a social construct. It means that we cannot just reach back to the "actually was" as if there were a pre-interpretative past that was "just there." The past is only received by us through the process of critical interpretation. Peirce, himself, gives us an example to show why the insistence that meaning always demands conjecture does not lead us to conclude that there is no past, but only that the meaning of the past cannot be reduced to a pure description:

It cannot be denied that acritical inferences may refer to the

220 R. DwORKIN, supra note 20 , at 226.

221 See 5 C.S. PEIRCE, supra note 28, ारी 481-82.

222 Id. II 453 (citation omitted). 
Past in its capacity as past; but according to Pragmaticism, the conclusion of Reasoning power must refer to the Future. For its meaning refers to conduct, and since it is a reasoned conclusion must refer to deliberate conduct, which is controllable conduct. But the only controllable conduct is Future conduct. As for that part of the Past that lies beyond memory, the Pragmaticist doctrine is that the meaning of its being believed to be in connection with the Past consists in the acceptance as truth of the conception that we ought to conduct ourselves according to it (like the meaning of any other belief). Thus, a belief that Christopher Columbus discovered America really refers to the future. ${ }^{223}$

Peirce, it is important to note here, is not arguing that there is no past. Indeed, his insistence on the category of Secondness indicates the material weight of the past that never can be recollected. As we have already seen, I am critical of Dworkin because he does not fully recognize how the past and with it the material suffering of others that cannot be made up does weigh on us. In this sense, I can be understood to argue that Dworkin fails to appreciate the significance of what Peirce calls Secondness. But given that the past cannot be fully recollected, it cannot be known other than through interpretation. The past, in other words, grasps us. We cannot grasp it. Yet it is precisely the "thereness" that we cannot interpret anyway that makes the past Secondness. The past is there, but not finished. We cannot wrap it up and present it in a determinate conceptual schema as Hegel wanted us to do. Yet even so, no one is denying that there wasn't a body of land that Christopher Columbus ran into in the past. (Yes, even the attribution of this act to a man named Christopher Columbus is an interpretive attribution.) But when we think about the full meaning of that "reality" we can only do so within an interpretive structure that is oriented to the future, in the sense that what it means that Ghristopher Columbus discovered America can only be resolved if we think about what it means for us to guide our conduct by that position. This future orientation does not also mean that there are not conditional resolutions within any given interpretative framework. But these resolutions can only be conditional, since reinterpretation is always a possibility. Yet to argue that reinterpretation is always possible is not necessarily to say that it is always a reality-since no one may call the conditional resolution into question. Past precedent, as institutionalized meaning, can be best understood as a body of "conditional resolutions." 
Conditional resolutions are conditional, then, precisely in the sense that there is no necessary relationship to their logical interpretant and, therefore, they can always be interpreted differently. In the case of law, we can know what the law means only if we open the text, which contains its "would be's" to the questions we are asking. The very effort to guarantee continuity of the spirit demands that we restate the normative message of the legal text. What we pass on, however, cannot be the letter of the law, as if there were a plain meaning that is simply there to be excavated, but instead must be its spirit. In this sense, as already suggested above, the enunciation of the legal principle inherent in the judge's decision implicates the "should be." Continuity in legal interpretation is always continuity in principle. A legal verdict is a creative supplement to the text, which once again brings the meaning of the text to life by telling us how we should guide our conduct in the future. $^{224}$ The reconstruction of principle to address the questions with which we are confronted does not arise out of a vacuum, but through the potential of the "might have been," which always remains in our reality of historical understanding. The very statement of what the law is in turn implicates the "should be," because it depends on justification of a particular interpretation since there can be no pure statement of what the law "is." There can be, in other words, no acritical reference to the past in the law that does not imply rational justification. I call this process of legal interpretation "recollective imagination." $225 \mathrm{We}$

224 Here we can give a different meaning to Derrida's insight that without the supplement there is no text. See J. DerRida, Dissemination 52-53, 63-64 (1981). In this very specific sense, infidelity to the past inheres in the very process of interpretation. Deconstructionists such as Derrida and DeMan show us that there is an inevitable moment of fictionality or literarity in legal and political interpretation. As we have seen through the analysis of Peirce, this is precisely because the other to thought and the otherness within thought itself disrupts the Hegelian recollection of the truth of the actual.

${ }^{228}$ Perhaps there is no better example of the practice of recollective imagination than that offered to us in the writings of the "new" civic republicans and also in the work of the dialogic communitarians. It is also precisely the self-conscious practice of recollective imagination that to some degree does separate the two groups. At least in American law, we may owe more to Cass Sunstein than to anyone else for showing us that within the tradition given to us by the Founders of the Constitution we can find " $a$ republican" view of constitutional government, with its emphasis on public virtue and the creation of a moral community as the essential goal of legality. Sunstein, Interest Groups in American Public Law, 38 STAN. L. REv. 29, 38-48 (1985). Although the republican ideal has not been the dominant trend within American constitutional law, Sunstein rightfully reminds us of what "might have been" if the legal community had emphasized a different aspect of our own tradition. Madison is undoubtedly the hero in Sunstein's work. Frank Michelman, on the other hand, in his Foreword to the Harvard Law Review, has questioned whether we can truly pull out of Madison's writings all that Sunstein finds there. Michelman, supra note 125, at 17-24, 58-60. More importantly, he has wondered whether there may not be a serious political dan- 
can draw out the implications of understanding legal interpretation as recollective imagination through the example of Roberto Unger's devia-

ger in the attempt to rely so heavily on an interpretation of Madison:

The main conclusion Sunstein wishes to draw is that Madison's solution was emphatically not "to accept the interest group struggle as a desirable part of politics that would promote social welfare." Rather Madison kept republican faith with the ideals of an objective public good and of the pursuit of this good through political deliberation. Having thus located in the Constitution this republican conception of politics-as a joint, goodfaith deliberation about the public good-Sunstein urges that this conception both supports and suggests reform of the doctrine of judicial review of the "rationality" of statutes and of various aspects of administrative process.

$\cdots$

. . . Sunstein's promise seems to reserve the ethically significant experience of self-government to the representatives; they are the ones who "have the virtue associated with classical republican citizens."

Id. at 59-60 (footnotes omitted).

For Michelman, there are contemporary problems and philosophical perspectives that were simply not present in Madison's time. Michelman is particularly concerned with Madison's rejection of the more radical vision of the republican tradition, which stresses the need for actual participation and self-government rather than the model of virtual representation. See id. at 58-59. Michelman finds in Sunstein's work the same tendency to play down the need to develop actual programs of participation consistent with a complex modern state and with the aspiration to individual freedom. See id. at 22-23. In like manner, Michelman has shown that an adequate civic republican conception of property is still in the making, not something we can find in any of the texts of the founding fathers. See id. at 55-57. When we recollect the conception of property in Madison, we are also asking ourselves what should be a civic republican view of property that could meet modern expectations.

Although Michelman does not explain himself in these terms, I would argue that Michelman's critique of Sunstein's over-reliance on Madison expresses his concern that recollective imagination can all too easily slide into Dworkin's "pretending." To pretend that history offers us more than it does undermines the critique of the past, which must also be a part of legal and, more particularly in this case, constitutional reconstruction. In his remarks on Sunstein, Michelman implicitly worries about the dangers of recreating history. See id. at 57-58. We should not pretend that there is a better view of law and politics in the tradition than is actually operative under even the most generous interpretation. We must always be clear that we are bringing out the potential of the might have been. Within the group of the new civic republicans and dialogic communitarians, it is Bruce Ackerman who has forthrightly argued for the essential role of imagination in highlighting the potential of our tradition. What I offer here is a reading of the interpretive method in his Social Justice in the Liberal State. B. ACKERMAN, Social JuSTICE IN THE LIBERAL STATE (1980). In that work, Ackerman spells out the conditions of dialogue he argues are inherent in an interpretation of the democratic constitutional tradition. Ackerman can be understood to argue that when we think about what is most fundamental to our constitutional tradition, it is the legitimation of the demand for reasons in the face of the inequalities of life. For example, Ackerman says that "[t]he fundamental problem for liberal political theory is to determine what you could possibly say that might convince me of the legitimacy of your claim to power." Id. at 327. The legitimation of power achieved through liberal theory's attempt to solve this "fundamental problem" implies the recognition that the citizens enjoy not only the right to respond but also the right to demand a justification. The state must, in other words, talk back and convince us with reasons, hence, the dialogic underpinnings of constitutional government are established. 
tionist doctrine. We will also see why Hegel's institutional analysis of the modern state remains relevant even once we have incorporated the post-modern disruption of his move to totality.

\section{The Example of Deviationist Doctrine}

In his recent book on the Conference of Critical Legal Studies, Roberto Unger argues that we can understand the spectrum of precedent through two pairs of principles and counter-principles: freedom to contract and community, and freedom of contract and fairness. ${ }^{226} \mathrm{We}$ can, perhaps, best understand Unger's analysis if we put it into the context of the Hegelian analysis of contract law discussed earlier. ${ }^{227}$ Unger argues that the sphere of freedom to contract is limited so as not to undermine the effective communal ties in the family. ${ }^{228}$ On the interpretation of his work offered here, although Unger certainly does not put it in this way, his central point is to give body to the norm of reciprocal symmetry which goes beyond what Hegel himself would have allowed within the sphere of private right. In Unger's work such a norm not only sanctions contractual relations; it also regulates the range of relations in which the contract should not be upheld, through the translation of the ideal of reciprocity into the counter-principle of fairness. Unger explains as follows: "Fairness means not treating the parties, and not allowing them to treat each other, as pure gamblers unless they really see themselves this way and have the measure of equality that enables each to look at himself." 229 As a result of the commitment to reciprocal symmetry,

[f]airness also means that inequality between the parties renders a contract suspect and, beyond a certain measure of disparity in power, invalid. In particular, unequal parties will not easily be read into a situation of mere gambling. When the limit of accepted and acceptable risks is reached or when the inequalities in the contractual relation begin to weaken the force of the contract model, the law will try to restore or invent a rough equivalence of performances or of participation in gains and losses. It may do so confusedly and covertly, but as long as the counterprinciple remains alive it will do so nevertheless. ${ }^{230}$

${ }^{226}$ See R. Unger, The Critical Legal Studies Movement, 60-75 (1986).

${ }^{227}$ See supra text accompanying notes 154-57.

${ }^{228}$ See R. UNGER, supra note 226 , at 62.

228 Id. at 73.

230 Id. at 74. 
By making explicit the underlying value of reciprocal symmetry in contractual relations and by applying it as a conversion principle, we can begin to shift the very parameters of the idea of freedom to contract. Hegel and Unger disagree over whether reciprocal symmetry is a "counter principle" to freedom to contract or is, instead, its very basis. Yet Hegel's own notion of what substantive reciprocity entails in the legal sphere of abstract right is so limited that it would have to be refashioned along Unger's lines if it is to continue to be useful for a modern understanding of contract. For the purpose of my analysis of how legal interpretation proceeds, this part of their disagreement is not important. What should be stressed instead is the relevance of the Peircean understanding of the indeterminacy of any semeiotic system of generals to a view of law as an interpretive praxis which constantly shifts the parameters of legal discourse itself.

The indeterminacy of the principles of the traditional contract model allows for the generation of a competing interpretation or, in Unger's sense, a "counter principle." The potential for a counter vision, in other words, is there in the indeterminacy of the present and in the indeterminate presence of our legal tradition of contract law. Radical lawyering, for Unger, is the practice of unleashing the potential of the tradition itself. ${ }^{231}$ The theoretical indeterminacy of legal doctrine as a system of signs leaves open opportunity for active intervention on the part of the individual lawyer. The reality of our established sittlich commitments is not just there and then reflected in the language of legal argumentation. Instead, the reality of Sittlichkeit is constituted and reconstituted in the very process of legal argumentation and judicial decision. Our legal reality, in other words, cannot be separated completely from what we do as lawyers, judges, and law professors. Nor is there a legal community that is self-present as a positive fact. The legal community is itself the embodiment and the expression of those who participate in making the legal world what it is. Very simply put, our conduct matters.

We can now put Unger's analysis of the development of the counter principle of fairness within contract law into a performative understanding of rights, which follows from the insight into legal interpretation as recollective imagination. Rights are only given meaning within the practice of an established language game or within a set of pre-given sittlich commitments. Unger tries to show us that the critical contest in contract law involves the respecification and the range of ap- 
plication of the principle and the counter principle. ${ }^{232}$ The rules of the game can be shifted within the terms of the lexicon of the right to contract itself. By shifting the rules of the game, we can also expand the boundaries of our form of life. The central insight of deviationist doctrine is that the meaning of rights is varied over time and space, through the very contest of the participants who attempt to realize their established sittlich commitments. In the act of narrating the past we deviate from it and interpret it differently, precisely because we can never fully recollect the has been. Because the discourse is always being reshaped, through the interpretation of law, there is then no "universal" language of right necessary to rights discourse. Nor do we need to reject the concept of right out of hand as the inevitable embodiment of the "possessive" individual. The aim of Unger's own system of rights "is to serve as a counterprogram to the maintenance or reemergence of any scheme of social roles and ranks that can become effectively insulated against the ordinarily available forms of challenge."2s3

To argue that rights discourse is always reshaped through the practice of legal argumentation is not to reduce rights to mere instruments, as Dworkin suggests, or to deny the relationship of rights to past decisions. Ironically, the understanding of the meaning of rights put forward here is the position consistent with Dworkin's own conception of law as interpretation. We are always in the process of reinterpreting the meaning of the rights given to us in past decisions through the projection of hypothetical meaning in the future as we conjecture what the right means in the case at hand. What is thought to be consistent with past decisions depends in part-but only in part--on our reinterpretations of the meaning of that past. The result that once seemed to express "consistency with principle" can, in light of new interpretation, appear inconsistent. The expression "as if" in pragmatic discourse indicates the future orientation of conditional generality. The meaning of rights, if rooted in the past, is always open to the future.

Unger, however, seems to take this insight into the future orientation of conditional generality to the incorrect conclusion that we must reject completely the idea that there is an intelligible ethical order objectified in the law. Yet, at the same time, he argues that

deviationist doctrine sees its opportunity in the dependence of a social world upon a legally defined formative context that is in turn hostage to a vision of right. . . . It is the legaltheoretical counterpart to a social theory that sees transform- 
ative possibilities built into the very mechanisms of social stabilization and that refuses to explain the established forms of society, or the sequence of these forms in history, as primarily reflecting practical or psychological imperatives. ${ }^{234}$

There is a difference, frequently obscured in Unger's critique of objectivism, between the argument that a certain vision of rights is imperative and the suggestion that a particular conception of rights is embodied, if imperfectly, in our legal institutions. As I have suggested, the understanding of meaning as an open-ended activity, which implicates the "would be" allows us to constantly expand the horizon of established rights discourse. But it is still the case that in law we uncover the "should be" in the might have been. If one went to the opposite extreme and denied all reality to Sittlichkeit or to Unger's "mechanisms of social stabilization," deviationist doctrine would itself become an impossibility. Unger does not merely argue that the principles and counterprinciples are "there" in his head; on the contrary, he argues that they are "objective," there in the doctrine. ${ }^{235}$

As we have seen, to argue that the principles and counterprinciples are not purely subjective but are also "there" in the reality of Sittlichkeit, is not necessarily to justify them as defensible. ${ }^{236}$ This is the mistake of those who believe that they can answer the indeterminacy thesis simply by an appeal to an institutionalized social reality. As we have also seen, the enunciation of what the law is implicates the "should be" through the justification of principle. ${ }^{237}$ An intelligible moral order may well fail to live up to the normative standards implicit in the self-image of the legal order itself. Intelligibility, in other words, is only the first step in legal interpretation. But the very idea of actualizing potential inherent in Unger's understanding of deviationist doctrine depends on our ability to designate the competing tendencies within our "reality of historical understanding." In like manner, the idea of deviationist doctrine still appeals to a coherent whole, which can be apprehended in its division into a principle and a counterprinciple. Unger argues that we can rationally grasp the underlying principles of contract. $^{238}$

Hegel reminds us that a modern legal system rests on its implicit appeal to rational justifiability and cognitive accessibility. It is precisely because the self-image of the modern legal order incorporates the ap-

234 Id, at 21.

${ }^{236}$ See id. at 60.

${ }^{236}$ See supra note 196 and accompanying text.

${ }^{237}$ See supra note 225 and accompanying text.

${ }^{238}$ See R. UNGER, supra note 226, at 58-60. 
peal to rationality that the failure of rationality is seen as a failure. We can, then, disagree with Hegel's assertion that we can apprehend the truth of a fully reconciled actuality and still incorporate his insight that the embodied, rational self-image of a modern legal system facilitates the possibility of immanent critique. The rational self-image depends on what Dworkin calls "consistency in principle," in which contradictory legal principles are synchronized by an appeal to a rational whole. ${ }^{288}$ In Hegel, the rational whole is the self-conscious recognition of the " ' $\mathrm{'}$ that is ' $\mathrm{We}$ ', and the ' $\mathrm{We}$ ' that is ' $\mathrm{I}$ " ' in the actualized relations of reciprocal symmetry. ${ }^{240}$ Legal principles are rendered consistent with the ideal of reciprocal symmetry or, perhaps more accurately stated, legal principles are grasped correctly in their essence only if they are understood as the embodiment of relations of reciprocal symmetry. ${ }^{241}$ The very rebellion against Absolute Knowledge has important consequences for the way we think about the appeal to a rational whole, but it does not demand that we reject such an appeal out of hand.

We can now recast one line of work in the conference of Critical Legal Studies. The "irrationalist" members of the conference have criticized the purportedly rational synchronization of "legal liberalism" as fundamentally contradictory. ${ }^{242}$ Although the writers of these texts may not agree with me, I read their works as "allegories," which trace the reality of a fall from a projected self-image of rational synchronization. The condemning force of this story lies precisely in the failure to live up to the projected rational self-image of the modern legal order. On any reading of this work, the whole is only there negatively as that which is not. Without its negative presence there would be no critical or condemning force, only the precritical demonstration that there are two sides to every issue. To heed the promise of synchronization as a critical force, we need not endorse constructive coherence as if the promise had been realized. We can do it equally well by marking its failure.

It is the tension between the promise of synchronization and the failure of its achievement that should open the law to its own trans-

299 See R. Dworkin, supra note 20, at 88; text accompanying note 78 .

240 Phenomenology, supra note 134, 1177.

241 See supra notes 151-63 and accompanying text.

${ }^{242}$ See Dalton, An Essay in the Deconstruction of Contract Doctrine, 94 YALE L.J. 997, 1006 (1985) ("[T]he various guidelines proposed by liberal legalism lack the clarity on which the liberal order presents itself as depending."); Kellman, Trashing, 36 Stan. L. REv. 293, 305-06 (1984) ("Mainstream" arguments are either "inevitably grounded in the emptiest generalities imaginable" or, in the case of economic theory, are "openly unempirical Utopian speculation about the nature of self-interest."). 
formative potential. I am using the word synchronization deliberately, because I believe it more accurately describes the aspiration of a modern legal system than does coherence. As already suggested, ${ }^{243}$ there are serious problems with the effort to develop a coherence theory of truth. That coherence seems to locate the problem of legal interpretation in some kind of theory of meaning, which does not specifically address the institutional, normative role of law. Synchronization, on the other hand, does point us to the real problem: How do we develop an institutional analysis of modernity which allows us not only to synchronize the competing rights of individuals, but also the conflicts between the individual and the community? The goal of a modern legal system is rational synchronization and not rational coherence. Synchronization recognizes that there are competing rights situations and real conflicts between the individual and the community, which may not be able to yield a "coherent" whole. The conflicts may be mediated and synchronized but not eradicated. In Dworkin, rational coherence depends on the community acting as a single speaker. ${ }^{244}$ In reality, a complex, differentiated community can never be reduced to a single voice. Synchronization recognizes the inevitable complexity of the modern state.

Nor is synchronization just balancing. It is "balancing" in and through an appeal to the "conversion principle" of reciprocity. Without closure, the ideal cannot be justified by an appeal to coherence. Its only justification is that it allows us to synchronize our effectively competing ideals better than any other ideal we have yet to develop. The refusal of closure that inheres in the post-modern rebellion against Hegelianism projects the rationally synchronized whole into the future as a promise that never can be fully realized. But as Derrida reminds us, "a promise is not nothing, it is not simply marked by what it lacks to be fulfilled."245

Preventing closure, or the achievement of rational coherence, can prevent us from searching for the best possible justification that Dworkin's community of principle should seek. Openness to rethinking the justification for our sittlich commitments can lead to the challenge to the legitimacy of past precedent. To be open to that challenge is to be open to the nomos, or to reason as a reforming power. To quote Robert Cover: "Legal meaning is a challenging enrichment of social life, a po-

243 See supra notes $126-33$ and accompanying text.

244 See R. Dworkin, supra note 20 , at 225 ("The adjudicative principle of integrity instructs judges to identify legal rights and duties, so far as possible, on the assumption they were all created by a single author-the community personified-expressing a coherent conception of justice and fairness.").

245 Derrida, Des Tours de Babel, in Difference in Translation, 165, 191 (J. Graham ed. 1985). 
tential restraint on arbitrary power and violence. We ought to stop circumscribing the nomos; we ought to invite new worlds."246 The pragmatic critique of Hegel as I have defended it through the encounter with Charles Peirce does precisely that: ${ }^{247}$ it stops circumscribing the nomos and invites us to new worlds.

\section{The Subject as Innovative Capability and the NoRmative Basis of COMMUNITY}

\section{A. The Normative Basis of Reasoning}

For Peirce, the reforming power of reason is implicit in its inherently ethical character. According to Peirce, we only reason about those thought processes that we can control. ${ }^{248}$ We reason in order to guide our conduct. It is the unique range of activities open to self-control in the human being that separates her from other conscious forms of life. Peirce explains as follows:

[T]here are inhibitions and coordinations that entirely escape consciousness. There are, in the next place, modes of selfcontrol which seem quite instinctive. Next, there is a kind of self-control which results from training. Next, a man can be his own training-master and thus control his self-control. When this point is reached much or all the training may be conducted in imagination. When a man trains himself, thus controlling control, he must have some moral rule in view, however special and irrational it may be. But next he may undertake to improve this rule; that is, to exercise control over his control of control. To do this he must have in view something higher than an irrational rule. He must have some sort of moral principle. This, in turn, may be controlled by reference to an esthetic ideal of what is fine. There are certainly more grades than I have enumerated. Perhaps their number is indefinite. ${ }^{249}$

According to Peirce, we need to know when we are reasoning in order to be reasonable human beings, rather than just creatures of habit. We need, in other words, leading principles, which help us to

${ }^{246}$ Cover, The Supreme Court, 1982 Term-Foreword: Nomos and Narrative, 97 HaRv. L. REv. 4, 68 (1983).

${ }^{247}$ See supra text following note 196; notes 197-199 and accompanying text.

${ }^{248}$ See 2 C.S. PEIRCE, supra note 28, it 182 ("[R]easoning is deliberate, voluntary, critical, controlled, all of which it can only be if it is done consciously.").

2495 C.S. PEIRCE, supra note 28, I 533. 
distinguish when we are reasoning from when we are just following an already established pattern of mind. Peirce believed that we can determine what these leading principles were in warranting the transition from premises to conclusions, regardless of the particular form of reasoning-deduction or induction-in which we are engaged. Peirce explains:

That which determines us, from given premisses, to draw one inference rather than another, is some habit of mind. . . The particular habit of mind which governs this or that inference may be formulated in a proposition whose truth depends on the validity of the inferences which the habit determines; and such a formula is called a guiding principle of inference. ${ }^{280}$

For Peirce, the process of reasoning incorporates the claim to validity: "a person who draws a rational conclusion, not only thinks it to be true, but thinks that similar reasoning would be just in every analogous case."251 The leading principles that are essential to reasoning itself are implicated in the claim to validity. We know that our conclusion is warranted because we know that we reasoned properly.

The very idea of reasoning properly is an ethical, as well as a logical, judgment. Logic for Peirce is dependent on ethics because logic involves an appeal to norms. ${ }^{252}$ A normative science studies "what ought to be" and, for Peirce, when we study the process of reasoning, when we assess whether or not a person has reasoned well, inevitably we presuppose norms of what proper reasoning entails. As Peirce explains, "[i]t is, therefore, impossible to be thoroughly and rationally logical except upon an ethical basis." ${ }^{253}$ We cannot, then, just describe our reasoning process without implicating evaluation, because the very description of reason rests on an ethical basis. If we are to assess our own reasoning, we must look at the norms themselves, which are implicit in any given view of what is proper reasoning. In order to assess these norms, we must confront our ultimate goals and purposes. For Peirce, the ethical basis of reasoning leads us to subordinate both the logical and the ethical to a vision of the final good. Of course, Peirce is not alone in reaching the conclusion that there is an inevitable relationship between what we think of as good judgment or proper reasoning

${ }^{280}$ Id. If 367.

2511 G.S. PEIRCE, supra note 28, II 606.

${ }_{252}$ See 2 C.S. PeIRCE, supra note 28, $\{198$ ("[L]ogic is a study of the means of attaining the end of thought. It cannot solve that problem until it clearly knows what that end is. Life can have but one end. It is Ethics which defines that end.").

253 Id. 
and a view of the good. Aristotle taught us that lesson long ago. ${ }^{254}$ Yet Peirce does have a unique understanding of the summun bonum. The summum bonum is the realization of concrete reasonableness. Peirce gives eloquent voice to "concrete reasonableness" in the following manner:

So, then, the essence of Reason is such that its being never can have been completely perfected. It always must be in a state of incipiency, of growth. It is like the character of a man which consists in the ideas that he will conceive and in the efforts that he will make, and which only develops as the occasions actually arise... [T] The development of Reason requires as a part of it the occurrence of more individual events than ever can occur. It requires, too, all the coloring of all qualities of feeling, including pleasure in its proper place among the rest. This development of Reason consists, you will observe, in embodiment, that is, in manifestation. The creation of the universe, which did not take place during a certain busy week, in the year 4004 B.C., but is going on today and never will be done, in the very development of Reason. I do not see how one can have a more satisfying ideal of the admirable than the development of Reason so understood. The one thing whose admirableness is not due to an ulterior reason is Reason itself comprehended in all its fullness, so far as we can comprehend it. Under this conception, the ideal function of conduct will be to execute our little function in the operation of the creation by giving a hand toward rendering the world more reasonable whenever, as the slang is, it is "up to us" to do so. ${ }^{255}$

The role of the judge, as well as the law professor, is to render our legal world more reasonable.

\section{B. The Communitarian Basis of Knowledge}

The process of reassessment through an appeal to the nomos cannot be encompassed by one individual. The very idea of critical evaluation demands a trans-individual perspective. According to Peirce, when we reflect on our established habits, we do so on the basis of an internal dialogue with ourselves as a projected other. Peirce explains his

254 See Aristotle, Nicomachean Ethics 3-4 (M. Oswald trans. 1962).

208 See 1 C.S. PeIRCE, supra note 28, II 615. 
communitarian conception of the thought process itself:

[A] person is not absolutely an individual. His thoughts are what he is "saying to himself," that is, is saying to that other self that is just coming into life in the flow of time. When one reasons, it is that critical self that one is trying to persuade; and all thought whatsoever is a sign, and is mostly of the nature of language. ${ }^{258}$

If thought is embodied in signs, then the very idea of the internal dialogue demands a set of norms and standards already in place. Here, Peirce anticipates the Wittgensteinian insight that thought takes place in language, which is public and shared. ${ }^{257}$ If there is no "private" language, then there is no purely individual thinking.

\section{The Normative Underpinnings of Community}

For Peirce, the historical reality of the community of inquirers is the basis for all knowledge. ${ }^{268}$ The community proves itself to be real as it converts its understandings of operative rules into habits. ${ }^{250}$

But for Peirce, the community is not only a positive fact but also an evaluative body. As we reason, we are also evaluating the reasoning process, because this is what it means to reason. Reason in this sense is a process of assessment. "Thinking is a kind of action, and reasoning is a kind of deliberate action; and to call an argument illogical, or a proposition false, is a special kind of moral judgment . . ."260 Peirce not only recognizes the possibility of dissension, but also argues that the very understanding of reason as assessment breeds critique and divergent opinions. ${ }^{281}$ The community of inquirers is guided by norms of dialogic reason and the standards necessary for intersubjective understanding. ${ }^{262}$ These norms can in turn be used to assess the actual process of inquiry in any given community. We judge the community by the embodied norms of reasoning.

\section{The Possibility of Developing a Conversion Principle Within the Democratic Tradition}

Why do we need the critical standard of an ethical conception of

\footnotetext{
256 5 G.S. PEIRCE, supra note 28, I 421.

257 See Tractacus, supra note $12, \pi 91$.

258 See supra notes $213-14$ and accompanying text.

258 See supra note 95 and accompanying text.

2808 C.S. PEIRCE, supra note 28, T 191.

281 See supra note 255 and accompanying text.

262 See 5 C.S. PeIRCE, supra note 28, II 565.
} 
reason? When we argue for one interpretation of the law in court, we argue for its validity in the sense that this is what the law should be if we adhere to the best possible justification of principle. Of course, we seek to persuade the judge, but we seek to persuade the judge on the basis that ours is the valid interpretation. When the judge vindicates one interpretation over another, she does not claim only that in her opinion one interpretation is more valid than another; she says this is the legal principle that should be perpetuated. Truth, in the sense of the claim that this is the interpretation of principle that the community of inquirers would hold to, is implicit in the very structure of legal decision. It is thus not only law professors who make this kind of claim. With the judge's decision, the dialogue and the debate end at least temporarily. But the elaboration of the justification of legal principle which carries within it criteria for the assessment of competing interpretations also leaves open the possibility of reassessment. Essential to this process of reasoning as assessment and reassessment through the recollective imagination of the community is the development of what I would call conversion principles.

By "conversion principle" I mean the act of recollective imagination which not only recalls the past as it remembers the future, but also projects forward as an ideal the very principles it reads into the past. A conversion principle both converts the way we understand the past and converts our current practice of interpretation as we attempt to realize it in the reconstruction of law. Recollective imagination allows us to develop a "conversion principle" from within the democratic constitutional tradition itself. ${ }^{263}$ The conversion principle can then serve both as a point of critique and as a regulative ideal of justice.

It would be a mistake to understand a conversion principle to convert the "is" of law into an "ought." As we have seen earlier, the "is" of law contains the "should be" in the enunciation and justification of principle. ${ }^{264}$ I put "is" in quotation marks deliberately. The critique of positivism insists that law is not simply "there" prior to the act of interpretation. But as we have also seen, the "reality" of law also is not just something in our heads. ${ }^{285}$ Laws do come to "exist" both through the process of enforcement and in the act of interpretation. The central lesson of both Dworkin and Hegel is that the "existence" of law in a democratic society cannot be separated from its claim to normative authority. As a result, the "existence" of law always demands interpretation and reconstruction. The "should be" is connected to the "would

263 See id. at 327-35.

${ }^{264}$ See supra notes 76-78 and accompanying text; text following note 111.

28s See supra notes 67-68 and accompanying text. 
be," in that there is no past acting as a dead weight. When the judge defends a legal principle as justified, she also argues that is what the law "should be."

The moment of "fiction" or "literarity" in the act of interpretation is what allows us to tell a "new" story and to project the stories we read into the tradition as constitutive of that tradition, as well as regulative of who we might become. The conversion principle I offer is a dialogic recasting of the Hegelian "ideal" of reciprocal symmetry. ${ }^{288}$

\section{E. The Institutional Implications of the Peircean Critique}

The pragmatic critique of Hegelianism has implications for the way we understand the ideal of reciprocity. The "dialogic" turn in constitutional interpretation initiated in the work of Bruce Ackerman ${ }^{\mathbf{2 6 z}}$ shows that the notion of dialogue as a normative relationship has expanded the Hegelian understanding of reciprocal symmetry to include a substantive understanding of inequality, which Hegel himself would not have accepted. Unlike Hegel, Ackerman has argued that it is precisely the demand for reasons in the face of inequality, that is the very essence of the dialogic relation between citizens and between citizens and the state. Any deviation from full substantive equality must be justified in and through dialogue if one's standing as a citizen is to be respected.

The emphasis on substantive inequality has implications for the way we think about reciprocity within the sphere of contract. ${ }^{268}$ In like manner, the focus on equality demands that we expand Hegel's own understanding of the institutions of the modern state to include participatory bodies and structures, which Hegel would have thought unjustifiable. For Hegel, the community nomos of the modern state is the demand for the concrete realization of freedom. ${ }^{269}$ Yet because Hegel shares the communitarian insight that individual identity is a social achievement, the demand for the actualization of individual liberty is also a demand for a properly constituted community. There is an emphatic interdependence here; individual liberty requires public freedom, and there is no authentic public freedom without individual liberty. Therefore, within the context of the modern state, we can no longer think of a shared or collective good as something to which the individual must necessarily subordinate herself. On the other hand, public

${ }^{268}$ See supra text accompanying notes 144-45.

267 See B. Ackerman, Reconstructing American Law 96-101 (1984).

${ }^{208}$ See supra notes 154-64 and accompanying text.

${ }^{269}$ See supra note 182 and accompanying text. 
freedom is necessary if we are to take the notion of self-realization seriously. Hegel was no advocate of radical democracy. ${ }^{270}$ Indeed, he did not even believe in a universal suffrage, yet his conception of the modern legal system as embodying relations of reciprocity ${ }^{271}$ continues to be valid in spite of his own limited view of democratic politics. This is, at least in part, because of his understanding of the public conditions necessary for freedom.

The horizontal dimension of reciprocity stems from the recognition that relations between individuals are rooted in material need. There is no person who is just there, prior to her engagements with others. Personhood is the basis of the equality of respect the state must show to each one of us as a citizen. ${ }^{272}$ But personhood is a social achievement dependent on the actualization of relations of reciprocity. The horizontal dimension of reciprocity then is what yields the modern concept of the legal person. In this sense, the horizontal dimension of our actual relation vis-à-vis one another should be privileged over the ethical dimension of our individual relation to the state. The Hegelian perspective, at least potentially, shows how the ideal of equality is the attainment of personhood.

Karl Marx took the horizontal dimension of the ideal of reciprocal symmetry so seriously that he saw no need for the state, once the ideal had been realized in socialist society. ${ }^{273}$ For Marx, the state was at one time necessary to protect the hierarchical relation of class society. But once the class society, which is inherently unequal, was overthrown, there would be no need to mediate the relations between individuals who were truly in relations of reciprocity to one another. This is one reason for Marx's serious neglect of the role of political and legal institutions in a socialist society. Although we may criticize Marx for this neglect, we can nevertheless recognize the challenge that Marx presents to us in his argument that genuine relations or reciprocal symmetry cannot be concretely realized in a state that continues to perpetuate-through the protection of certain forms of private property-the status distinctions that the ideal is intended to break down and

270 See supra text accompanying notes 171-74.

${ }^{271}$ Cf. PhIlosophy of Right, supra note 23, at 182-83 ("The usual sense . . . in which men have recently begun to speak of the 'sovereignty of the people' is that it is something opposed to the sovereignty existent in the monarch. . . . Taken without its monarch and the articulation of the whole which is the indispensable and direct concomitant of monarchy, the people is a formless mass and no longer a state.").

${ }^{272}$ See Baker, Outcome Equality or Equality of Respect: The Substantive Content of Equal Protection, 131 U. PA. L. Rev. 933, 959 (1983).

${ }^{273}$ See C. Gould, Marx's Social OnTology 166 (1978). 
overcome. ${ }^{274}$

We can translate the horizontal dimension of reciprocal symmetry into a principle of nonsubordination that certainly expands the traditional notion of formal equality. No citizen should be systematically relegated to a subordinate status vis-à-vis other citizens because of her gender, race, or nationality. It is the wrong of systematic subordination that was perpetuated in the practice of segregation in the United States. None of Dworkin's own theories of equality he offers us in his discussion of Brown reaches the principle of nonsubordination, which is why his own wording of the wrong in Plessy is that it was an insult to blacks. But it was not that segregation was an insult to blacks, it was instead the systematic promotion of their social subordination. The principle of nonsubordination also helps us to grasp the difference between an illegitimate and a legitimate recognition of one's race, gender, or nationality. Programs, such as affirmative action, which take race and sex into account but do not promote subordination, are not only acceptable, they are crucial if we are to truly try to realize the horizontal dimension of reciprocity. No voice should be silenced because of systematic subordination. If we are to take participatory democracy seriously, it must be based on a principle of nonsubordination. In order to develop a conception of government as the collective freedom of a genuinely participatory democracy, we must move beyond both Hegel and Marx and yet heed Hegel's warning that freedom must be protected and embodied in an institutional structure. Frank Michelman has explained the political goals of dialogic communitarians in the following way:

First, the object of self-government is freedom. That object lies partly in constituting the governed as sovereign over their governors. But freedom's connection to self-government does not lie only, or ultimately, in the protective function of popular sovereignty, invaluable though that function is. Freedom in its fullest sense is self-government, active engagement in a self-directive process that is cognitive as well as volitional, hence (given our social constitutions and situations) public as well as private, political as well as personal. ${ }^{275}$

The ideal of the protection of the public sphere is crucial if actual dialogue between citizens is to be possible. It is not enough, then, for

276 Michelman, supra note 125 , at 73. 
law simply to protect the formal equality between citizens; the horizontal dimension of dialogic reciprocity must be taken seriously. I have argued elsewhere that the horizontal dimension of dialogic reciprocity would lead to a shift in emphasis in our conception of rights, to emphasize the right of participation. ${ }^{276}$ This shift, in turn, is consistent with the communitarian view of the subject, as constituted in and through its internal relations to the other.

\section{F. Why Dialogic Reciprocity and Not Integrity}

I have already indicated the dilemma inherent in Dworkin's community personified. ${ }^{277}$ As Michelman also suggests, the irony implicit in Dworkin's tale of Hercules is that it marks the absence, not the presence, of a real community. ${ }^{278}$ Dialogic reciprocity, on the other hand, does preserve the reality of the community nomos that is "there" before us, and also provides us with a regulative ideal by which we guide our striving to become a community of principle based on the institutionalization of freedom. Dialogic reciprocity, in other words, unlike integrity, gives us an ideal that allows us to justify in the name of principle our infidelity to certain aspects of our democratic tradition as it has been embodied in constitutional precedent.

But, of course, whenever we break with precedent in the name of the "should be" inherent in the "might have been" of an indeterminant past, we must justify the violation of the rule of law. Indeed, as I have argued, Dworkin's integrity falters as a conversion principle precisely when he wants to use it to justify a break with precedent. Integrity, in other words, can be understood as an ideal inherent in the rule of law which justifies its perpetuation, but not its subordination to other principles. Dworkin's integrity cannot justify transformative interpretation even though the practice of Hercules frequently seeks the transformation of legal principle and not its perpetuation. Of course, the very ideal of the rule of law itself can not escape from "the truth" of indeterminacy. The process of categorization in the attempt to put together "like" cases, is always imperfect, itself an act of interpretation. There is no such thing as pure perpetuation of the law.

It is precisely the iterability of language that makes consistency as exact replication impossible, and therefore, change and innovation inevitable. Jacques Derrida has brilliantly shown us how the iterability of

${ }^{278}$ Cornell, Beyond Tragedy and Complacency, (forthcoming in Nw. U.L. REv.).

277 See supra text accompanying notes 121-23.

${ }^{278}$ See Michelman, supra note 125 , at $72-73$. 
language implies both sameness and difference. ${ }^{279}$ Words as signs are iterable, or repeatable, by any general user. ${ }^{280}$ In other words, language is possible precisely because public standards allow intelligibility. Derrida shows us that it is the very contextual character of language that allows for both understanding and communication and for misunderstanding and the development of new meanings. The very sittlich character of language, in other words, precludes its total encapsulation within any particular context. Described in this way, the intersubjectivity of language-its capacity to function as a vehicle for the repetition of the same by different subjects-is ironically a vehicle for innovation. At the same time, as a language functions to repeat the same message by different subjects, it retains its capacity to be turned away by a reader or a bearer from what it meant to its issuer so that it continues to mean something, but not identically what it meant to its writer or utterer. ${ }^{281}$

Linguistic context, then, does not erect barriers against innovation. Instead, it provides for the possibility-indeed the inevitability-of innovation. Unless there is an appeal to an ideal self-sameness which guarantees the exact repetition of meaning, the very meaning of the context itself will be constantly shifting. It is exactly our tacit sense of the possible that always changes as we are offered new interpretations.

Yet to argue that no ideal self-sameness can guarantee the replication of meaning is not to deny the reality of institutionalized meaning. The argument simply means that we recognize that our boundaries are always shifting precisely because of the fluidity of linguistic context. Innovation is inevitable because of the open-endedness intrinsic to the intersubjective character of language. This explains why there can be no simple appeal to what it is through interpretation.

A different point, however, should be emphasized. The ideal of the rule of law demands fidelity to principles embodied, if only imperfectly, in past precedent so as to protect conditions of legal personhood. It is not that adherence to the past is in and of itself a good; the good is instead that we acknowledge that legal subjects must be recognized in their individuality by the state. A crucial aspect of such recognition is the protection of the individual's expectation so that individual agency is allowed to flourish within the cognizable boundaries set by the law. Without such recognition individual agency would be undermined and the state would fail to meet its duty to protect personhood. But as we have seen, Hegel correctly understands that the conditions of per-

${ }^{279}$ See Derrida, Signature Event Context, in 1 GLYPH 172 (1977).

280 See id. at $179-80$.

281 See id. at 180-85. 
sonhood, in turn, demand the realization of relations of reciprocity. We can therefore justify transformative interpretations of legal principle in the name of the conditions of personhood that themselves justify the rule of law.

The ideal of dialogic reciprocity guides us in our effort to be true to the spirit of a democratic conception of law. Of course, if we break with Hegel's system in the name of an inevitable indeterminacy, we can no longer argue that there is a dynamic telos which inevitably leads to the actualization of dialogic reciprocity in the modern democratic state. Instead, we must rely on rational commitment to this ideal, because it allows us to synchronize most effectively two of our deepest political and legal ideals, freedom and equality. Of course, this synchronization is not perfect. But this inevitable imperfection does not mean that we cannot argue for its relative success in comparison with competing conversion principles, such as Dworkin's integrity.

In spite of imperfectability, a Hegelian understanding of the philosophy of right still promotes the role of law as synchronization of competing ideals. ${ }^{282}$ Of course, once we recognize that the process of recollection of legal principle is never mere exposition but involves the imagination and the positing of the very ideals to be read into the legal text, we can no longer choose between competing interpretations on the basis of an appeal to what is just "there." All interpretations entail an inevitable moment of fictionality. As a result we cannot prove the truth of a particular conversion principle. We can only evoke its power and justify its rightness through argumentation. This does not mean that all interpretations are equally effective in the synchronization of competing ideals. It does mean that only through argument can we show that one interpretation is better than another. To say that there can always be a better interpretation than the one we now offer is not to say that there necessarily is such an interpretation now available to us. Power, of course, plays a crucial role in designating both who is to decide what is better and on what criteria that decision should be based. But the reality that there are embodied ideals that guide the interpretive process in art or in law at least potentially puts some limit on what those in power can impose. That such ideals can be constituted against the endless power-bargaining of actual individuals is the hope of constitutional government. It is a hope, however, that depends on interpreters of the law for its reality against those who say it is only wishful thinking. Of course, if we accept that law is nothing more than power, then there is always the possibility that this is what law will become. This is just a 
possibility, not a mandate of fate.

More importantly, it is precisely this process of elaborating ideals that becomes crucial once we understand the inevitable moment of evaluation in legal interpretation. The misunderstanding of the indeterminacy thesis, which argues that indeterminacy denies the power and the hold of institutionalized meaning, has yielded a number of attacks against it which simply insist that there is, indeed, institutionalized meaning. ${ }^{283}$. In Hegelian language, they appeal to the existence of Sittlichkeit. Such assertions, while relevant to discussions of how communication and intelligibility arise but certainly not dispositive of such discussions, do not help us much in the area of legal interpretation unless they explicitly address the problem of normative authority. If one reads carefully, it is evident that-except for a few extreme cases ${ }^{284}$-all sides of the debate do agree that there is institutionalized meaning. The real difference between the competing sides of the debate is whether or not it is possible to elaborate standards of "rightness" through an appeal to the potential inherent in embodied ideals within the law, which can in turn be used to judge what has been institutionalized. The "truth" of indeterminacy is that, from within the social reality as we find it, we can always imagine a better world by interpreting the "would be" inherent in the conditional generality of law. Peirce always reminds us of the immanent potential to invite new worlds, but Peirce himself, although he recognized indeterminacy, also projected a hypothetical closure in the community of inquirers.

Unlike Peirce, I do not accept that an ultimate convergence of opinion is either desirable or possible. Convergence in such a strong sense would obscure the diachronic moment of any semeiotic field, which marks the transcendence of what is. Emmanuel Levinas has eloquently explained the danger in any attempt to silence once and for all Dworkin's external or internal skeptic: "Does not the coherent discourse, wholly absorbed in the said, owe its coherence to the State, which, violently excludes subversive discourse? Goherence thus dissimulates a transcendence, a movement from the one to the other, a latent diachrony, uncertainty and a fine risk." ${ }^{\text {285 }}$

283 See Stick, Can Nihilism be Pragmatic?, 100 HARv. L. REv. 332, 387-89, 392-

284 There are moments, for example, when both Peller and Boyle are close to embracing the position that there is no institutionalized meaning that constrains the play of signifiers in a semeiotic field. See Boyle, The Politics of Reason: Critical Legal Theory and Local Social Thought, 133 U. PA. L. Rev. 685, 721 (1985); Peller, The Metaphysics of American Law, 73 CaLIF. L. Rev. 1151, 1167-70 (1985).

${ }_{285}$ E. Levinas, Otherwise Than Being or Beyond Essence 170 (A. Lingis trans. 1981). 
The doubt that inheres in the very division of any sign in a semeiotic field is indeed a "fine risk," one with which we simply have to live. We should not try to speak as a single voice. Banishment has too long been the answer to the one who questions the institutionalized meanings and norms of the community. ${ }^{286}$

\section{G. The Self as Innovative Capability}

Who is the "we" to whom the invitation to release the nomos can be delivered? In Peirce's early writings he focused on overcoming doubt through the stabilization of belief. In his later work, however, he became increasingly dissatisfied with his own account of habit as it was related to his conception of self-control and of reason. ${ }^{287}$ Sam Weber explains the tension that moved Peirce beyond his earlier understanding:

To establish belief and habit means to establish an interpretation of one's words that will overcome the intrinsic divisions of those words as signs. Doubt is therefore not-as Peirce himself seeks constantly to convince himself-merely the "absence" of belief, its simple negation: it is a consequence of the divided structure of the sign. Within the individual subject, this takes the form of what Peirce calls "selfreproach." The stronger the habit the less this feeling of selfreproach will be. However, "the more closely this is approached"- that is, the "fixed character" imparted to actual habit-"the less room for self-control there will be; and where no self-control is possible there will be no selfreproach."288

I would replace Peirce's self-control with the "innovative capability" that inheres in the self's inevitable intersection with otherness. Transformation, in other words, is demanded of us precisely because there is no self-enclosed subject who can truly cut herself off from the other. We are constantly being challenged by otherness. We do not need reason to control ourselves, but rather in order to transform ourselves as we attempt to guide rationally our conduct in the face of new challenges. The role of reason is to enhance our innovative capability,

${ }^{288}$ See, e.g., 5 C.S. PeIRCE, supra note 28, ๆ 372 ("Doubt is an uneasy and dissatisfied state from which we struggle to free ourselves and pass into the state of belief ...." (reprinted from 12 Popular Science Monthly 1, 5 (1877))). 1903 ")

${ }^{287}$ See, e.g., 1 C.S. PEIRCE, supra note 28, If 606 (from the "Lowell Lectures of

${ }^{288}$ S. Weber, INSTITUTION AND INTERPRETATION 14 (1987). 
which, in turn, increases our ability to re-imagine our world and our place in it.

There is a distinction between the view presented in the reinterpretation of Peirce offered in this Essay and a more traditional Kantian understanding of the role of autonomy. In Kant, the subject of reason, the transcendental subject, is the "I," which commands the empirical subject of desire. ${ }^{289}$ Reason, in Kant, is pitted against desire, in part because desire itself is relegated to an empirical "property" of the concrete "me." 290 The concrete "me" of empirical desire is a reality. One does not so much change that "me" as control it. What I am suggesting is that the role of reason is to change that "me" of empirical desire. This is possible because there is no empirical "me" that is simply there. In the Hegelian conception, desire is itself social and contextual and therefore open to re-interpretation. Desire is not a "property of the empirical self' but an intersubjective relation.

Let me give an example, which will emphasize the significance of the distinction I am trying to make. Think of a man whose sexual "desire" has been thoroughly shaped by the cultural stereotypes presented to him in pornographic literature. His dilemma is that his desire is out of touch with his own conception of what a relationship between men and women should be like. Under the Kantian schema, he should try to control the desiring "me" through the reasoning "I." Under the Peircean schema offered in this Essay, he will be pulled to transform his desires through the challenge to his habitual practice of desire inherent in his own conception of the ideal and in his contact with those he desires. He will not so much force himself to change as he will be forced to change. Yet he can also assess the changes in himself. He can assess as well as accept his habitual structure of desire as it inevitably breaks down in his contact with others. It is this process of assessment that allows him to intervene in what is happening to him. Of course, all change is not necessarily desirable. Even so, reasoning and thinking in Peirce is connected to the ability to accept and to enhance change. Thinking in Peirce is related to "musement," that openness to new worlds, which prods us to wonder about what we once took for granted. Reasoning is more akin to musing over what we once accepted as we let ourselves be invited to new worlds than it is to the assertion of control over the desiring self. Thinking in this sense demands our openness to

${ }^{289}$ See I. KANT, Critical Examination of Practical Reason, in KANT's CRITIQUE of Practical Reason and OtHer WORKS ON THE THEORY OF ETHICS 109-16 (T. Abbott trans. 6th ed. 1909), reprinted in KaNT Selecrions 289-95 (T. Greene ed. 1929).

See id. at 112-16, reprinted in Kant Selections, supra note 289, at 292-95. 
otherness and our willingness to accept the invitation.

This appeal to innovative capability does not implicate a transcendental subject. It does, however, preserve what is valued in the idealist conception of autonomy, without endorsing a subject that can pull itself together and away from otherness. The ideal of autonomy has always been justified by the need for critical assessment of communal standards. We need the ability to say "no" as well as to say "yes" to our community. Peirce recognized that the traditional interpretations of the Kantian understanding of autonomy rested on the myth of a subject that could constitute itself as a transcendental subject. ${ }^{291}$ Not only is the Kantian subject a myth, it may worse yet be a description of a self whose habits are so encrusted that the illusion of her separateness prevents the acceptance of the invitation prodding us to think. But Peirce wanted to maintain the role of reason as assessment.

If we understand the role of reason as the enhancement of innovate capability, however, we can break through the distinction between the negative "no-saying" of the autonomous subject and the ecstatic giving away to the community that so frightens the liberal critic of communitarians. Reason allows us to criticize ourselves and our community, based on the potential for transformation. One says "yes" to the potential in oneself and in the community through the critique of what is and through the appeal to the might have been and the should be. This understanding of the self as "innovative capability" allows us to synchronize "critical" reasoning with the critique of the sovereign subject, who seeks to maintain herself against otherness.

As a result, this conception of the self as innovative capability does not deny that the subject is a stabilized entity immersed within a field of habits and a pre-given linguistic context. Indeed, such a view insists that it is the immersion in a pre-given context that marks the self as an interaction with otherness. This stability is always breaking down, because of the diachronic nature of any semeiotic field and because of the reality that we are always facing new circumstances. The very idea of repetition we associate with habit implies difference and modification. Thus it is more correct to describe the self as this process of modification or innovation than as the locus of habit. Again to quote Weber:

That "self" consists in all the factors contributing to habit change, to "a modification of consciousness" that entails modification of behavior. If it necessarily involves repetition it is in the sense assigned by Derrida to "iteration," which "alters." As Peirce writes "it naturally follows that repeti- 
tions of the actions that produce the changes increase the changes."282

It would, then, be a mistake to interpret the view of the self as innovative capability as a return to the individualism that denies the precedence of the community to the self-conscious subject. Indeed, the Peircean view of the subject is radically anti-individualist:

Now you and I-what are we? Mere cells of the social organism. Our deepest sentiment pronounces the verdict of our own insignificance. Psychological analysis shows that there is nothing which distinguishes my personal identity except my faults and my limitations-or if you please, my blind will, which it is my highest endeavor to annihilate. ${ }^{203}$

It is because of the precedence of the community to the self that the subject can not achieve self-enclosure and, in that sense, create herself as a substantive reality. Who "we" are is the intersection with otherness. As a result, we are constantly pulled to modify our habits. Innovative capability is not so much a property of the self as it is a potential inherent in our inevitable relation to otherness. Moreover, this description of the self as the potential of innovative capability can also be understood as a good to which we aspire. Rather than seek control through closure, we should instead open ourselves to the invitation that otherness constantly provides. The very image of the subject who strives for closure and control, rather than accept the invitation of otherness, is Odysseus as he ties himself to the mast before daring to listen to the sirens. ${ }^{294} \mathrm{He}$ is willing to hear them only once he has created a situation where he cannot respond. Of course, to tie oneself up is also a response. However, it is a response that resists rather than accepts the invitation.

Nor does the emphasis on "innovative capability" necessarily deny the desirability of the goal of narrative coherence in an individual life. ${ }^{285}$ Such a view asserts that narrative coherence is a goal, never a

${ }^{202} \mathrm{~S}$. WEBER, supra note 288 , at 15 (footnotes omitted).

2831 C.S. PEIRCE, supra note $28, \pi 673$.

284 See M. Horkheimer \& T. Adorno, Dialectic of Enlightenment 43-80 (J. Cumming trans. 1972).

${ }^{280}$ In his book, The Critical Legal Studies Movement, Roberto Unger has sought to justify a conception of the self as "Negative Capability." See R. UNGER, supra note 226, at 93-94. I have criticized elsewhere such a conception of self for both its masculine bias and its denial of the communitarian insight into the subject as socially constituted. See Cornell, supra note 276. What I want to argue here is that the view of the self I hold incorporates Unger's insistence of the centrality of "transformative" capability to self-hood, without endorsing his own conception of "negative capability." Unger's 
completely achieved actuality. The precedence of otherness denies the possibility of closure. Moreover, the aspiration to narrative coherence may well involve the very ability to be unfaithful to one's past in the name of the ideals or principles that one attempts to embrace as the very basis of narrative coherence. In Peirce, the "I" is significant only as it expresses the pull of the ideal. Consistency-in-fact is no more possible for an individual than for a legal system. "Consistency-in-principle" often demands infidelity to our past life and to the habits that have governed it. The ability to enhance one's innovative capability should, then, be understood to be essential to, indeed the very basis of, a life of narrative coherence.

\section{CONCLUSION}

In this Essay, I have argued that Dworkin's incomplete break with positivism and with nominalist conceptions of community does not allow him to develop a philosophical framework adequate to his own project. I have suggested that the Hegelian understanding of the inherently communal ethical basis of law does provide us with an anti-positivist framework that allows us to develop an understanding of what a properly constituted legal community would entail if it were to meet the requirements of the modern recognition of the person. But I have also argued that Hegel's institutional analysis of the role of right in the modern state could no longer be justified, as it is in Hegel, through an appeal to the realized fully determinate truth of the whole. Hegel, in other words, helped us to grasp the ethical and communal basis of law, but he did not and cannot provide an account of the transformative potential of law. As a result, his own philosophy of right ties us to the rock of the past. Yet, even so, his insight that a modern legal system rests in the ideal of reciprocity between citizens can be incorporated into the post-modern critique of Hegelianism. As we have seen, indeterminacy does not mean the collapse of the ideal into the mere existent. Instead, it breaks down the rigid divide between the "is" and the "should be."

The pragmatic critique of Hegelianism as developed in the work of Charles Peirce reminded us that the potential for transformative interpretation inheres in the very indeterminacy of the past. We reconstruct legal principle through an appeal to the "should be" in the "might have been." This appeal always implies justification and not just an interpretation of the "is." Whenever we claim validity for one

"negative capability" does seem to deny the desirability of a life of "narrative coherence." 
interpretation over another, we are implicitly justifying it. The process of justification itself rests on a conception of reasoning as assessment. The Peircean understanding of the inherently ethical basis of reason, in turn, allowed us to develop the normative concepts of reason that Dworkin needs but does not offer. Peirce also shows us that the communal basis of reasoning implies an understanding of community as a normative ideal and not just as a positive fact.

But Peirce himself did not develop a theory of legal interpretation or the role his insights might play in a political community could not provide us with an adequate understanding of legal interpretation as recollective imagination. In order to understand the process of legal interpretation and to grasp the continuing relevance of the Hegelian ideal of reciprocity and the role of law as synchronization, we had to elaborate on the significance of Peirce's pragmatic critique of the Hegelian framework. I also rejected Peirce's own postulation of closure through the convergence of opinion. We cannot silence doubt nor should we try. There can be no final culmination of the interpretive process. More specifically, I needed to develop an account of how and why the conversion principle of dialogue can justify a break with precedent as Dworkin's own principles of integrity could not do. Finally I confronted the question of what kind of subject we would have to be, however, to accept the invitation to transform our world. What kind of subject, in other words, must we seek to become if we are to "stop circumscribing the nomos and invite new worlds." We are left with the invitation to realize the potential inherent in the "would be's" of our social reality. The invitation is always there, but it is up to us to accept it. 
